\title{
A REVISION OF THE MEXICAN AND CENTRAL AMERICAN SPECIES OF VANILLA PLUMIER EX MILLER WITH A CHARACTERIZATION OF THEIR ITS REGION OF THE NUCLEAR RIBOSOMAL DNA ${ }^{1}$
}

\author{
Miguel A. Soto Arenas $\dagger^{2,3}$ \& Robert L. Dressler ${ }^{4,5}$ \\ ${ }^{2}$ Instituto de Ecología, UNAM, Circuito Exterior s.n. Ciudad Universitaria, \\ Coyoacán 04510 México D.F., MEXICO \\ ${ }^{3}$ Herbario AMO, Montañas Calizas 490, México, D.F. 11000, MEXICO \\ ${ }^{4}$ Lankester Botanical Garden, University of Costa Rica, P.O. Box 302-7050 Cartago, Costa Rica \\ ${ }^{5}$ Corresponding author: kerry@bio-photo.com
}

\begin{abstract}
AвSTRACT. We present a revision of the Mexican and Central American species of Vanilla. There are 15 different species in the area; Vanilla costaricensis, V. cribbiana, V. dressleri, V. martinezii and V. sarapiquensis are here proposed as new taxa, and $V$. pompona subsp. pittieri and $V$. pompona subsp. grandiflora are recognized at subspecific rank. Vanilla calyculata, V. hartii, V. helleri, V. inodora, V. insignis, V. odorata, V. phaeantha, V. planifolia, V. pompona and V. trigonocarpa are also described, illustrated, and their nomenclature, typification, distribution, and other aspects of interest are discussed. Additionally, we include a key to the species. Several Mexican and Central American species of Vanilla are closely related to V. planifolia, V. x tahitensis, and V. pompona, the cultivated species of the genus, and these are thus important in plant breeding. We also include a cladistic analysis of nucleotidic sequences of the internal transcribed spacer region of the nuclear ribosomal DNA, showing that this popular molecular marker is of sufficient variation to allow for species discrimination, permitting, with some exceptions that are discussed, the recognition of sterile samples and indicating that it is a good molecular marker to infer the phylogeny of this group. The similarity and relationship between $V . x$ tahitensis* and $V$. odorata is discussed.
\end{abstract}

Se presenta una revisión de las especies mexicanas y centroamericanas de Vanilla. Existen 15 especies reconocidas en el área. Vanilla costaricensis, V. cribbiana, V. dressleri, V. martinezii y V. sarapiquensis se proponen aquí como nuevas especies, $V$. pompona subsp. pittieri y $V$. pompona subsp. grandiflora también se reconocen con status subespecífico. Vanilla calyculata, V. hartii, V. helleri, V. inodora, V. insignis, V. odorata, $V$. phaeantha, V. planifolia, V. pompona y V. trigonocarpa también se describen, ilustran y se discuten aspectos de su nomenclatura, tipificación, distribución, relaciones y otros puntos de interés. Adicionalmente, se incluye una clave de identificación de las especies. Varias especies mexicanas y centroamericanas de Vanilla están cercanamente relacionadas a $V$. planifolia y $V$. pompona, las dos especies más frecuentemente cultivadas, y por lo tanto representan un germoplasma importante para este cultivo. Adicionalmente se presenta un análisis

\footnotetext{
${ }^{1}$ Editor's note: Miguel Ángel Soto Arenas passed away August 27th, 2009, before this manuscript was submitted for review. The working manuscript presented here was still unfinished at the moment of his death, and was recovered among Soto Arenas' electronic files. Despite its economic importance, Vanilla remains one of the most poorly studied of all large orchid genera, and both the editors and reviewers considered that this publication is an important addition to the orchid and general botanical literature. Ken Cameron, Phillip Cribb, Eric Hágsater, Gerardo Salazar, and Rodolfo Solano did their best to offer corrections and comments to the original draft manuscript. In some instances, however, Soto Arenas quoted preliminary analyses and refers to new taxonomic concepts we were unable to recover. We have not changed the letter of the original manuscript, and such cases are indicated by editor's notes to warn researchers in the future who will find anomalies or have concerns about some of the data.

* Editor's note: A paper on Vanilla tahitiensis has been published by Lubinsky et al., Neotropical roots of a Polynesian Spice: the hybrid origin of Tahitian vanilla, Vanilla tahitensis (Orchidaceae). Amer. J. Bot. 95(8): 1040-1047. 2008. In the article, the senior author acknowledges Soto Arenas for suggesting the topic of his $\mathrm{PhD}$ thesis.
} 
cladístico de secuencias nucleotídicas de la región de los espaciadores internos transcritos (ITS) de los genes nucleares ribosomales, donde se muestra que las secuencias de este marcador molecular ampliamente utilizado son específicas, lo que permite, salvo algunas excepciones que se discuten, el reconocimiento de muestras estériles y además lo hacen un buen marcador molecular para estudios filogenéticos en este género. Se comenta la similitud y relación entre $V$. tahitensis* y V. odorata, y el origen híbrido de la primera.

KEY WoRds: Orchidaceae, Vanilla, Vanilla calyculata, V. hartii, V. helleri, V. inodora, V. insignis, V. odorata, V. phaeantha, V. planifolia, V. pompona, V. trigonocarpa, Mexico, central Americas, new species

The Pantropical genus Vanilla Plumier ex Miller is a group of orchid vines with about 107 species (Soto Arenas, 2003; Soto Arenas \& Cribb, 2010). Vanilla is an ancient genus (Chase, 2001; Cameron, 2000, 2003) and the largest in the subfamily Vanilloideae (Soto Arenas, 2003). Some Vanilla species are grown as the source of an extract for flavoring and perfumery, especially Vanilla planifolia Jacks., with $V$. $x$ tahitensis J.W.Moore and V. pompona Schiede being much less cultivated (Correll, 1944; Purseglove, 1975). Vanilla exports generate US $\$ 60-80$ million in foreign exchange for producing countries (Smith et al., 1992), perhaps more at present, and it is the most profitable crop of the warm tropics.

The culture of $V$. planifolia and $V$. pompona originated in Mexico, probably in northern Veracruz (Bruman, 1948). Although frequently cited as native of Mexico and elsewhere, there were until recently very few records of $V$. planifolia from wild populations, and its precise original distribution is uncertain (Soto Arenas, 1999). Many Vanilla species are similar to $V$. planifolia in floral and vegetative traits, and abundant material in herbaria, both flowering and sterile, is usually misidentified as $V$. planifolia. Even some Mexican plantations planted with wild Oaxacan Vanilla vines include a mixture of $V$. cribbiana, $V$. insignis, $V$. odorata, and $V$. pompona, besides the true $V$. planifolia. Similar "mixed" plantations occur in Ecuador (P. Lubinsky, pers. com.) and Guatemala (Beza, pers. com.).

It is well-known that Vanilla has peculiarities that make it a taxonomically difficult genus (Wood, 2003), mostly due to the scarcity of flowering material (a result of the gregarious, ephemeral flowering, usually at the top of the forest canopy), the huge vegetative variation and phenotypic plasticity characteristic of

\footnotetext{
* Véase la Nota del Editor en la página anterior.
}

the hemiepiphytic growth habit (e.g. leafy and leafless shoots and differently shaped leaves on the same individual plant as in many hemiepiphytic aroids; Putz \& Holbrook, 1986; Ray, 1990), the poor preservation of the membranaceous, strongly three-dimensional flowers make them difficult to study, the notable floral similarities between many species, in part due to the pollination by Euglossine bees (which permits the maintenance of species with little morphological differentiation but with different floral fragrances (in other genera of orchids); Williams, 1982), and the problems derived from the less than perfect quality of type specimens. Additionally, some species are very rare, with sparse populations, and the vines are long-lived perennials that only flower when they have attained considerable size. Small pieces of these plants may be transplanted to greenhouses or gardens, but few of them ever attain the size and strength to flower. There are abundant data that indicate that $V$. planifolia is in danger of extinction in Mexico (Soto Arenas et al., 2004). Scarcity of material can be illustrated by the flowering behaviour of the only Mexican population of $V$. hartii, which was found in anthesis only after 7 years of observations. Vanilla helleri and V. martinezii are each known only from two flowering collections, while $V$. costaricensis and $V$. sarapiquensis are each known from a single pressed specimen. Vanilla phaeantha and $V$. helleri are here reported for the first time from Mexico, based on sterile material, whose ITS sequences match with properly identified material of these taxa. Most cultivated specimens of Vanilla in botanic gardens and living collections never produce flowers and therefore cannot be identified.

Vanilla plantations face several agricultural problems, the most important being the root rot disease caused by Fusarium batatis f. vanillae (Childers et al., 1959). It has been suggested that susceptibility to root rot is perhaps due to a narrow 
genetic variation, and that is to be expected in this crop due to its vegetative propagation (Purseglove, 1975; Purseglove et al., 1981; Smith, et al., 1992; Soto Arenas, 1999; Cibrián, 1999). A study of the circumscription of the cultivated species, their distribution, variation, and information on their related taxa, or those with which they may be likely confused is a necessary step toward the establishment of a germplasm bank and a breeding program in this orchid in order to enlarge the genetic foundation of the crop. In the absence of a thorough taxonomic revision, and phylogenetic framework, the breeding programs with Vanilla have used very distantly related species that are unlikely to produce fruits with commercially interesting aromatic properties (e.g. with $V$. aphylla, or V. barbellata).

The taxonomy of the Central American Vanilla species has been previously recognized as confusing (Dressler, 1993), and the available regional treatments are not accurate. Bouriquet (1954) revised the entire genus Vanilla, including the Central American species, but his study is out of date and he worked only with herbarium material. In "The Orchidaceae of Mexico", Williams (1951) listed four species as native of the country, one of them, $V$. pfaviana Rchb.f., is actually a synonym of $V$. inodora Schiede. In recent years, Soto Arenas $(1989,1994)$ reported additionally $V$. mexicana Miller and $V$. odorata. Later, Castillo and Engleman (1993) have cited significant differences in morphology, phenology, and compatibility behavior in the cultivars of $V$. planifolia (which suggested more than one taxon or a strong genetic structure within the species), and additional species have been recognized in Mexico in recent years (Soto Arenas, 2003; Hágsater et al. 2005). On the other hand, $V$. insignis Ames (1934) was described from Honduras, V. helleri A.D.Hawkes (Heller \& Hawkes, 1966) from Nicaragua, and V. pauciflora Dressler (Dressler, 1979) from Panama. Vanilla hartii Rolfe was reported from several countries of the area (Correll, 1965), and $V$. phaeantha Lindl. cited from El Salvador (Hamer, 1974). McLeish et al. (1995) listed three species from Belize; Hamer (1974) listed two taxa from El Salvador, and four for Nicaragua (Hamer, 1984), while Heller \& Hawkes (1966) mentioned five from this same country. Dressler (1993) included three species in his 'Field Guide to the Orchids of Costa Rica and Panama'. Dix and Dix (2000) reported four species for Guatemala. The brief treatment recently published for Costa Rica (Soto Arenas \& Dressler, 2003) lists ten species for this country, three of then unnamed, and it is largely based on the present revision.

Special mention is necessary for the enigmatic $V . \times$ tahitensis J.W.Moore, described from Tahiti, but apparently introduced to the botanic garden at Papeete from Manila, Philippines in 1848, together with the true V. planifolia (Pétard 1986: 123; Hermann et al. 1989: 20). Vanilla tahitensis is very similar in morphology to some Central American taxa, and very different from the Old World vanillas. No confirmed records of it, either wild or cultivated exist from Central America, or in any other American country, but evidence has been presented of its hybrid origin from $V$. planifolia and $V$. odorata.

A study of the historical records, literature, and field work, both in wild populations and plantations, has proven that some of the reports for Mesoamerica are based on misidentifications, some species must be reduced to the synonymy of previously described taxa, and that some other species of the area remain undescribed.

This revision of the taxonomy of Mexican and Central American vanillas, together with a molecular tool may permit the correct identification of material of this area, even if it is sterile. This is an important issue, in view of the necessity of identifying vegetative material of rare, economically important plants that seldom produce flowers.

For most Central American taxa, sequences of the Internal Transcribed Spacers of the nuclear ribosomal DNA (ITS) were obtained and proved to be speciesspecific with a high level of confidence, therefore, they represent a tool for the identification of sterile or juvenile living material. The ITS analysis is compared with sequences gathered from two larger, more difficult to sequence chloroplast genes $(r b c \mathrm{~L}$ and $m a t \mathrm{~K}$ ) in order to corroborate its utility.

\section{Material and methods}

Herbarium and spirit preserved material was studied in most institutions that house Central American orchids (AMO, AMES, BM, BR, CHAPA, CR, ENCB, F, G, GOEL, HEPF, K, INB, LL, MA, 
MEXU, MO, NY, P, RJ, SCZ, SEL, UCR, US, UV, $\mathrm{W}, \mathrm{WU}$, and XAL.). Efforts were made to study living material and wild specimens were observed in Mexico, Guatemala, Costa Rica, and Panama. Pollination observations and analysis of fragrances by gas chromatography (conducted by Dr. Neil da Acosta, Bush Boake Allen, London) were an additional element in circumscribing some taxa and are presented in detail elsewhere*.

Due to the phenotypic variation and plasticity seen in the vanillas and mentioned above, the descriptions of vegetative features were prepared only from flowering shoots, often under well-illuminated conditions. Stems and leaves of descending (shaded, ground-oriented shoots) are etiolated, often thinner, or even leafless. On the other hand, Vanilla flowers frequently show strong shrinkage in flower dimensions after being pressed; for this reason the measurements of $V$. cribbiana, $V$. hartii, $V$. inodora, $V$. insignis, $V$. martinezii, $V$. odorata, V. planifolia, $V$. pompona, and $V$. sarapiquensis were taken from living and/or spirit preserved flowers. For the rest of the species the dimensions were taken from pressed specimens, and those of $V$. calyculata and $V$. trigonocarpa also include measurements of living specimens published elsewhere.

In those species in which more than five different specimens (perhaps not necessarily different clones in the case of $V$. planifolia) were available, either in fresh condition or in spirit, the dimensions of flowering features are also given in mean and standard deviation, in order to determine the possible range of variation more accurately. The flowers of all herbarium material examined were boiled or reconstituted in a solution of ammonium hydroxide.

Internal Transcribed Spacer (ITS) sequences of nuclear ribosomal DNA were collected in order to determine if this widely used molecular marker could be a useful tool to identify material. The sampling (see Table 1) does not include $V$. costaricensis nor $V$. sarapiquensis from which adequate tissue samples were not available. A special effort was made to confirm the specific identity of the specimens, even of some sterile ones. Due to difficulties in preparing vouchers, some samples remain unvouchered; however, several are housed at AMO or MEXU; pictures of other plants are kept in M. Soto's files (which eventually will be deposited in AMO), but no voucher specimens are known to exist for most plants in living collections (e.g. Royal Botanic Gardens Kew, Nancy Botanic Garden, Jardín Nacional de Cuba, Marie Selby Botanical Gardens, Missouri Botanical Garden, Finca La Gavilana), although they were confidently identified from the living material, and locality data may help to eventually confirm the identity of the populations. Sequences of South American specimens of the $V$. pompona complex were also included. Also a sequence of $V$. claviculata, from Puerto Rico, another of $V$. barbellata, from Florida, and another from $V$. mexicana Miller, species reported for our area from unconfirmed records, were also included. The sequences of Epistephium parviflorum and Lecanorchis multiflora were defined as outgroups. It is unknown which is the sister genus of Vanilla, although morphological data suggest that it is likely Dictiophyllaria, a poorly known genus which is known only from the type specimen (Soto Arenas, 2003). Epistephium, Clematepistephium, Eriaxis and Vanilla form a polytomy in a cladistic analysis of sequences of the plastid gene $r b c L$. On the other hand, Lecanorchis (achlorophyllous, and in which amplification of $r b c L$ gene has been unsuccessful) was found to be sister to Vanilla from analysis of the nrDNA gene $18 \mathrm{~S}$, although a more complete sampling of this region places Epistephium sister to Vanilla (Soto Arenas, unpublished data)**.

DNA was extracted mostly from fresh leaves using a method based on Murray \& Thompson (1980), or from leaves preserved in silica gel (Chase \& Hills, 1991). Better quality DNA was obtained using liquid nitrogen and adding $2 \%$ of PVP to the extraction buffer. Vanilla tissues oxidize badly when they are pressed, especially in the Membranaceous species; all attempts to extract DNA from herbarium specimens failed, although bad quality DNA has

\footnotetext{
* Editor's note: The manuscript "Notes on the floral biology of mexican Vanilla (Orchidaceae) and the evolution of pollination systems in the genus" has been found among Miguel Angel's unpublished manuscripts.

** Editor's note: It is unclear to which data the senior author refers here.
} 


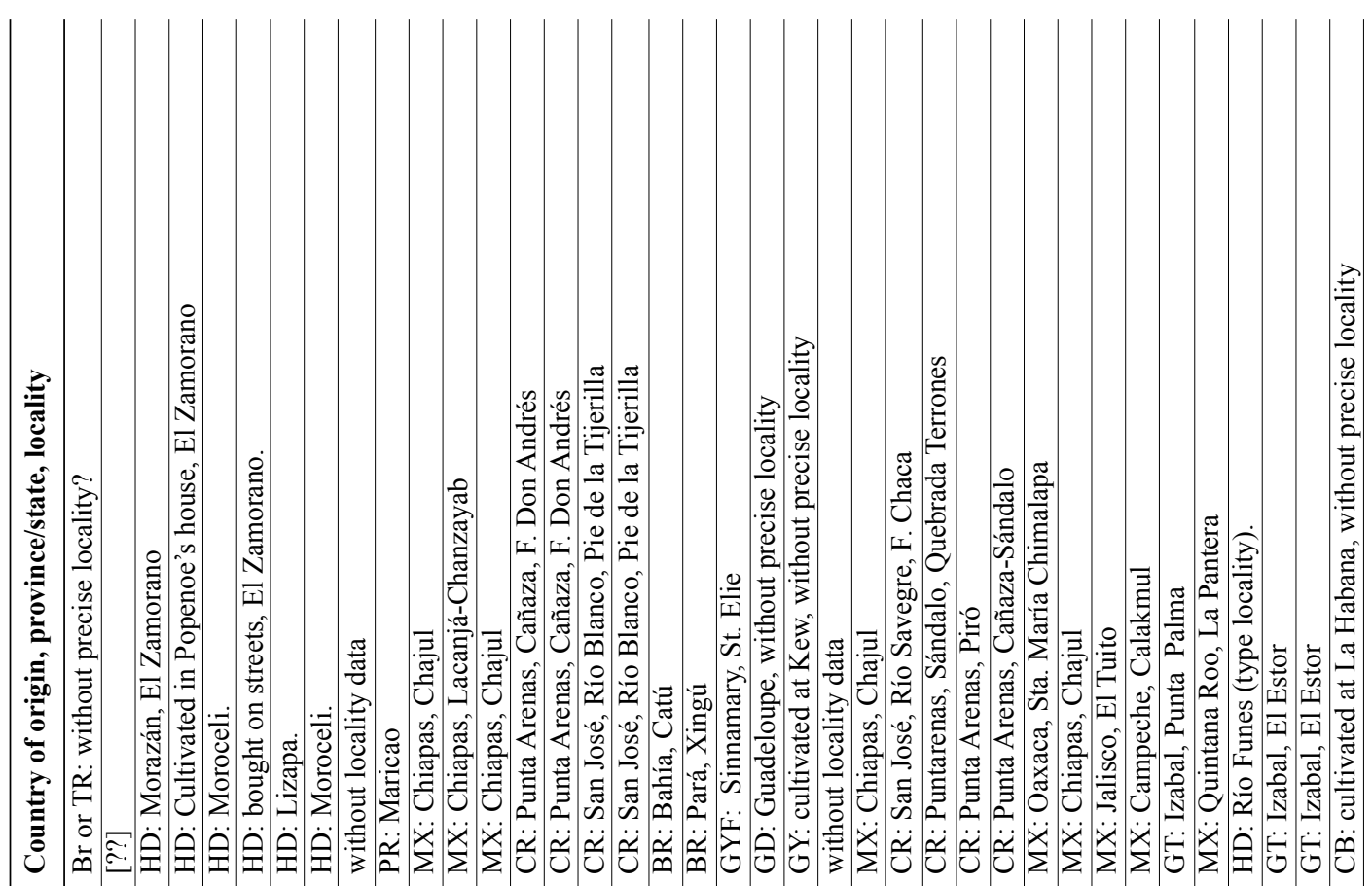

$\stackrel{0}{\sim}$

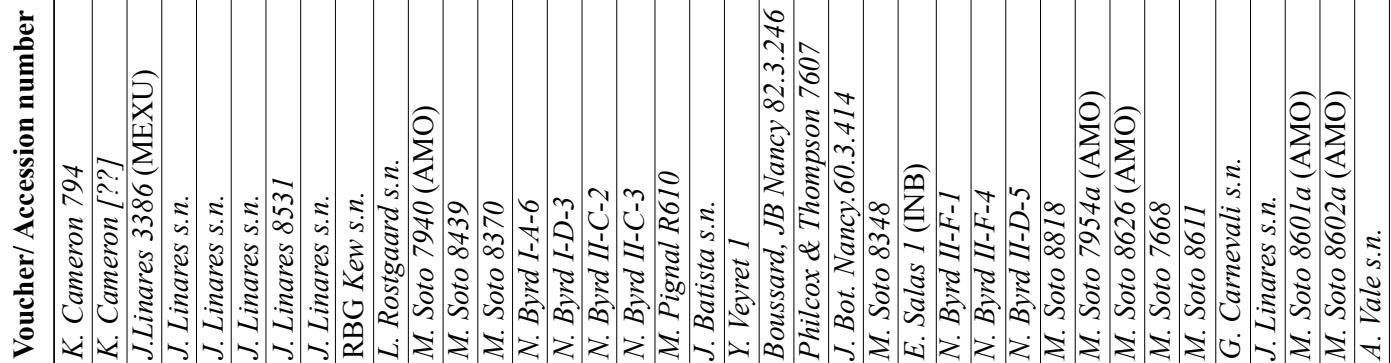

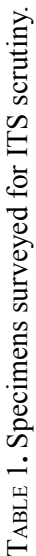

$\sqrt[3]{2}$

$\frac{5}{2}$

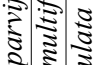

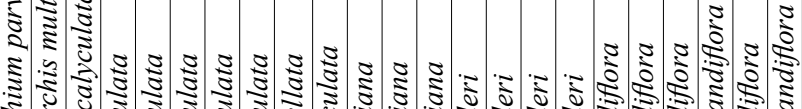

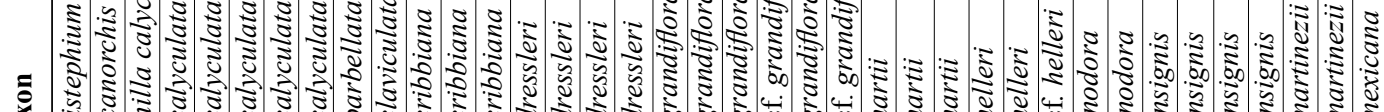

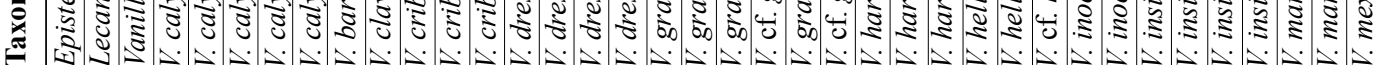




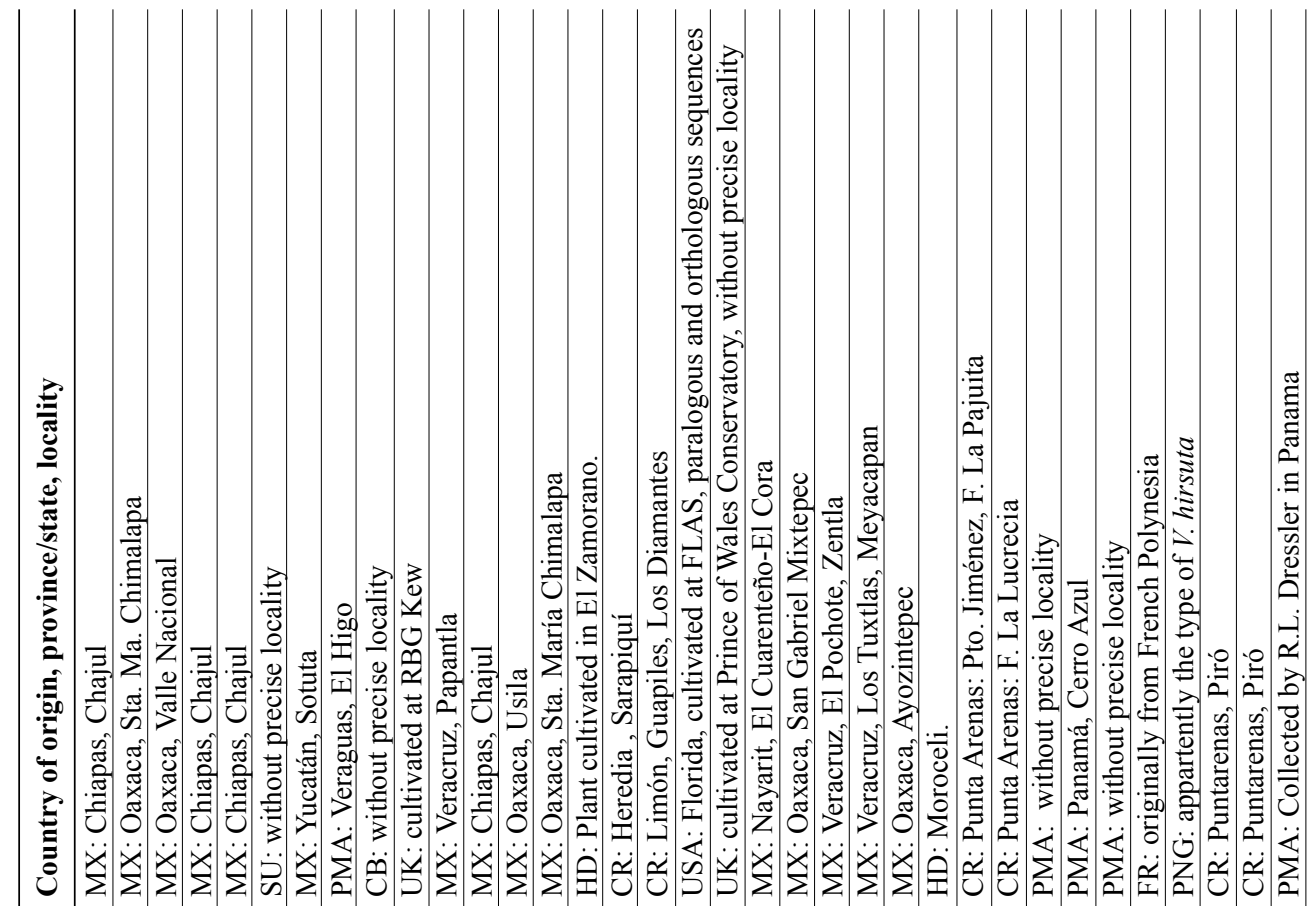
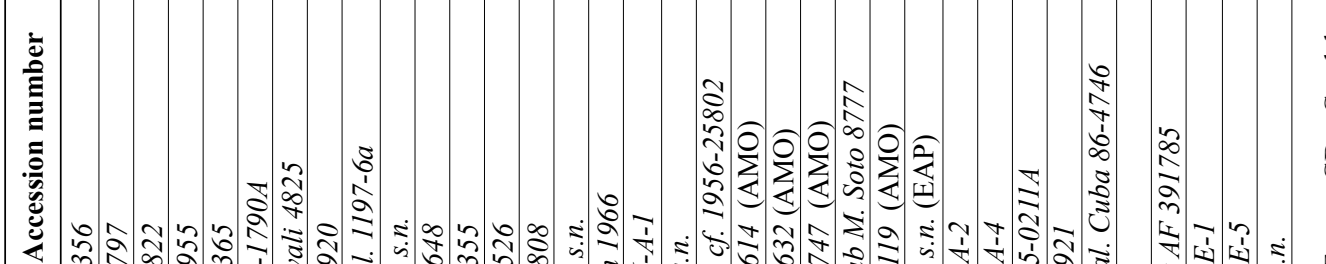

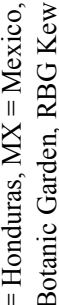

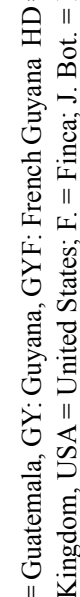

它

ํ.

它

芩

छे

กิ่

宁

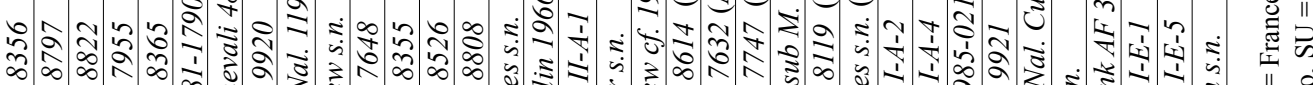

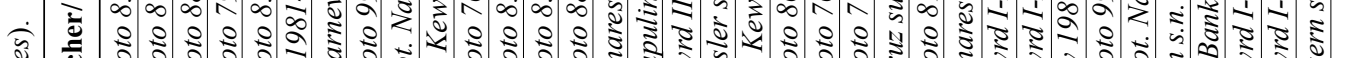

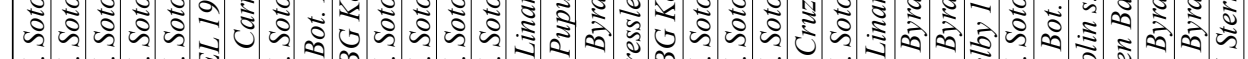

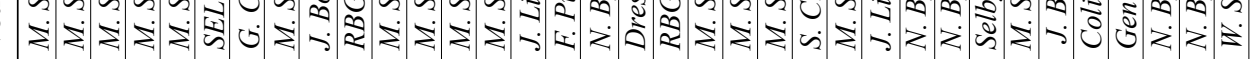

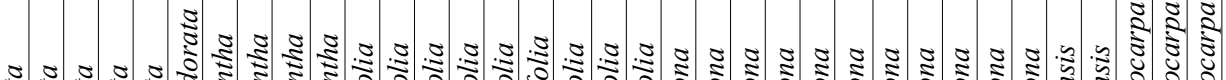

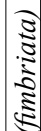

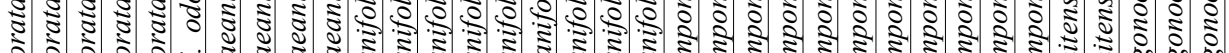

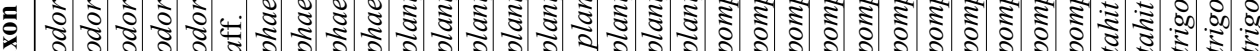

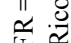
요울 窟 $\bigcup_{0}^{\infty} \frac{1}{2}$ 焉 的 已 ชิ 震 की 背要 正 苂 竞 恶 $5 \pi$ 4
4 
been extracted from a couple of South American and Asian herbarium specimens of other species. The ITS region, including the $5.8 \mathrm{~S}$ gene was then amplified with the primers ITS2, ITS3, ITS4, and ITS5 (White et al. 1990; Baldwin, 1992) or 17SE and 26SE of Sun et al. (1994). PCR reactions were better when $3 \%$ of DMSO was added to the cocktail. PCR products were run in low melting point agarose gel and the band cut to be extracted with QIAGEN Gel Extraction Kit (QIAGEN, Ltd.) or QIAquick silica columns (QIAGEN, Ltd.) adding guanidin chloride (35\%) to remove primer dimers. Bi-directional sequencing was performed using cycle-sequencing (ABI Prism dye terminator cycle sequencing ready reaction kit, PE Applied Biosystems, Inc.) with the same primers with which they were amplified using different automated sequencers following manufacturer's protocols. Electropherograms were edited using EditView, and the resulted sequences were initially aligned using Clustal x (Thompson, 1995) and adjusted by eye. Although alignment of Vanilla species is easy, the alignment with the outgroups is largely ambiguous and alignment is based mostly on the lengths of the regions. Phylogenetic analysis was performed with PAUP* 4.0 (Swofford, 1998) with the following specifications: Epistephium parviflorum and Lecanorchis multiflora were defined as the outgroups. An heuristic search with equally weighted parsimony analysis. The analysis consisted of 1,000 replicates with SPR swapping and 20 trees saved per replicate, to save time swapping on islands with large numbers of trees and allowing the detection of multiple islands of equally parsimonious trees (Madison 1991). Then another equally weighted parsimony analysis was performed, swapping to completion of all the trees from the previous analysis. This was followed by a bootstrap analysis, holding 10 trees per replicate for 1000 replicates, using SPR swapping and MULPARS. Bootstrap values were obtained from 100 replicates.

\section{Results}

We recognize 15 Vanilla species in Mexico and Central America. A key and a taxonomic treatment are presented in the following pages. Five species,
Vanilla costaricensis, V. cribbiana, V. dressleri, V. martinezii, and $V$. sarapiquensis are proposed as new species and three subspecies are recognized within $V$. pompona (the typical subspecies, subspp. pittieri and grandiflora).

Amplification of PCR products was better with primers 17SE and 26SE of Sun et al. (1994) and with them only a single band was obtained. Two bands, one probably from and endophytic fungus were sometimes amplified using primers ITS4 and ITS5.

The analysis of nucleotidic sequences resulted in 669 characters, from which 246 were constant, and 271 sites were parsimony-informative. The heuristic search yield a total of 39,090 most parsimonious trees (tree length $=1070$ ). The strict consensus of this tree is presented in Fig. 1.

This tree is largely congruent with phylogenetic analysis based on morphological and molecular characters, either of plastid ( $r b c L$ gene, Soto 2003; matK gene, Soto \& Alvarez-Buylla, unpublished), of nuclear sequences (18S and ITS sequences from species from all the world). In all the analysis two main groups of Vanilla are recognized. One of them includes the Membranaceous vanillas ( $V$. inodora and $V$. martinezii in the tree; $V$. costaricensis and $V$. sarapiquensis, from which DNA was not available belong to this clade). The other lineage of Vanilla includes the leafless plus the leafy, nonmembranaceous species.

Two very dissimilar sequences of $V$. planifolia were obtained from two different $P C R$ reactions of the specimen Dressler s.n. (cultivated at FLAS). One of these sequences is practically identical to other eight sequences of the same species included in the sample. The anomalous $V$. planifolia sequence goes sister to a $V$. mexicana sequence, forming a clade which occupies a basal position to the rest of Vanilla. When Clematepistephium smilacifolium and Eriaxis rigida are included into the analysis, this clade occupies an intermediate position between ClematepistephiumEriaxis-Epistephium and Lecanorchis (data not presented). Vanilla mexicana is the type species of the genus, and closely related to, even difficult to separate from, other membranaceous vanillas (e.g. $V$. martinezii and $V$. inodora). These anomalous sequences make both Vanilla and the defined outgroup non-monophyletic. The $r b c L$ (Soto Arenas, 


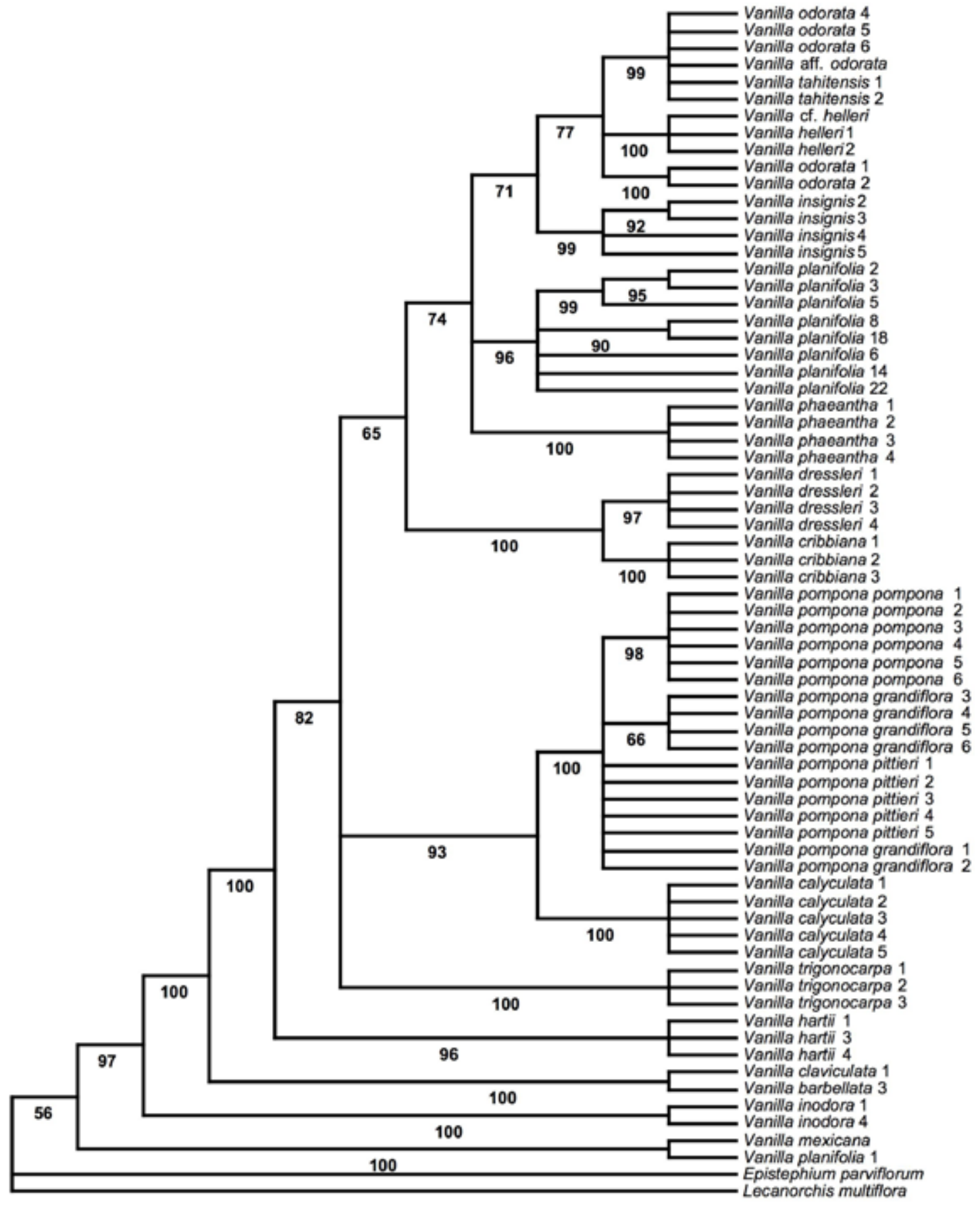

FIGURE 1. Strict consensus from 30,090 minimal trees obtained from ITS sequences of the nuclear ribosomal DNA. 
2003), matK, and $18 S$ topologies (Soto Arenas et al., in prep) are incongruent with the position of these two particular sequences of Vanilla and we regard them as paralogous ITS copies. Cloning in 10 PGEM a PCR product of $V$. cf. kaniensis Schltr. (a species from New Guinea) yield three different ITS clones which differ only in 1 and 2 DNA bases and are clustered together in the ITS phylogeny, therefore ITS is a very useful identifying tool.

Other paralogous ITS sequences of Vanilla (from species of other regions) have occasionally resulted, especially when DNA has been extracted from herbarium specimens or less often from tissues dried in silica gel. No more paralogous copies of American vanillas have been detected, and both included represent the two main lineages in the genus. If they are excluded, both the defined outgroup and Vanilla become monophyletic. The paralogous sequences are largely divergent, and therefore easily identified. This is probably because the duplication event that produced them seems to have been previous to the separation of Vanilla from their related groups.

The leafless group is not well-documented from Mesoamerica (see discussion in 'Excluded taxa'); a Puerto Rican specimen of $V$. calyculata and another of $V$. barbellata were included. There are no confirmed reports of these species from Mexico or Costa Rica, respectively; in any case, it is rather surprising that leafless taxa are absent in Yucatán, very close, and with similar habitats to places in Cuba where leafless vanillas are present. The rest of the Mesoamerican vanillas belong to the group recognized by Soto (2003) as "American fragrant Vanilla spp." Phylogeny of Vanilla is discussed in more detail in Soto (2003).

What is important for identification purposes is that ITS sequences are largely species-specific, since the species form monophyletic groups with very high bootstrap support.

The only exceptions are $V$. odorata which proved to be paraphyletic, since $V$. helleri and $V$. tahitensis are nested in it. Two samples from east of the Tehuantepec Isthmus share a different ITS sequence. Vanilla tahitensis sequences are not different from most of $V$. odorata, a result which is not incongruent with a the hypothesis of a recent hybrid origin of this taxon (between V. planifolia and V. odorata), as its morphology suggests. The Vanilla pompona complex has a bootstrap value of $99 \%$. All the Mexican samples of $V$. pompona plus two specimens (SEL 1985-0211A and a sequence in the Gen Bank U66819) form a clade with $99 \%$ of bootstrap support. Several South American specimens of $V$. grandiflora form a weakly supported (63\% bootstrap value) branch, and the rest of the South American specimens of $V$. pompona and the Costa Rican, Honduran, and Panamanian specimens of the $V$. pompona complex form a polytomy at the base. This structure in the V. pompona complex is congruent with the distributional disjunctions and suggests that an infraspecific classification of the species is required.

In conclusion, ITS sequences are a very useful tool to separate sympatric, vegetatively indistinguishable vines like $V$. planifolia, $V$. helleri, and $V$. cribbiana, or to identify specimens with juvenile or etiolated vegetative characters. We suspect that one of the reasons for the lack of an important breeding effort in Vanilla has been due to the difficulties of identifying material.

The origin of $V$. tahitensis has been much argued. These data indicate clearly that $V$. tahitensis is very closely related to $V$. odorata. Vanilla tahitensis is clearly a member of the American fragrant clade of vanilla, characterized by leafy plants and penicillate calluses, and which is absent in the Old World Tropics (as in New Guinea) where the vanillas geographically nearest to Tahiti occur), therefore the hypothesis that it was introduced recently to Tahiti is strongly supported. Since vegetatively it has much broader leaves than $V$. odorata, it is almost certain that it is not conspecific with this species. The flower is larger than in $V$. planifolia, and it is rather intermediate in all traits between $V$. planifolia and $V$. odorata.

These molecular data, and other unpublished data including many more species from other areas, suggest that $V$. phaeantha, $V$. insignis, $V$. helleri, $V$. odorata, and $V$. tahitensis are the closest relatives of the vanilla of the commerce, $V$. planifolia, even much more closely related than $V$. pompona with which it has formed hybrids that are at present cultivated. The close relatives all have fragrant fruits and have different habitat preferences; thus they represent a pool of interesting traits with potential to be incorporated into this crop. 


\section{KEY TO THE SPECIES AND SUBSPECIES}

1. Leaves thin, membranaceous when dry, sometimes slightly chartaceous, rachis of the inflorescence lax with remote bracts; lip united only basally to the column $(<4 \mathrm{~mm})$, column smooth or basally keeled, but without substigmatic hairs; lip without a penicillate callus formed by a tuft of laciniate scales, instead, the callus may be formed by longitudinal keels, or very fleshy cushions .............................................................. 2

2. Bracts of the inflorescence foliaceous, very large, similar to small leaves ............................................ 3

3. Lip distinctly trilobed, midlobe emarginate-bilobed, callus massive, cushion-like …............... V. inodora

3. Lip subentire, truncate at apex, callus made up of 2 prominent axial keels and several warty lateral keels

V. costaricensis

2. Bracts of the inflorescence scale-like, small $(<1 \mathrm{~cm}$ long)

4. Lip ca. $42 \mathrm{~mm}$ long, with low callus made up of several axial, longitudinal, warty keels .......... V. martinezii

4. Lip ca. $32 \mathrm{~mm}$ long, with a massive callus made up of 2 broad, fleshy, sulcate, apically confluent keels

V. sarapiquensis

1. Leaves thick, coriaceous to fleshy, chartaceous when dry; rachis of the inflorescence dense with approximate bracts; lip attached to the column up to the stigmatic region, usually $>2.5 \mathrm{~cm}$, column with trichomes on the ventral surface, lip with a penicillate callus formed by a tuft of laciniate, retrorse scales

5. Lip without a clear claw, rather cuneate, strongly trilobed, the midlobe short, transversely oblong and covered by conspicuous, complanate papillae along nerves

V. helleri

5. Lip conspicuously long-clawed, claw usually very distinct from the blade, the latter entire to trilobed, the midlobe variously shaped, smooth or variously covered with papillae, trichomes or warts

6. Flowers very large, lip $>10.5 \mathrm{~cm}$ long, inflated, margins crenulate-plicate, racemes few-flowered (2-3)

V. trigonocarpa

6. Flowers not so large, lip $<9 \mathrm{~cm}$ long, inflated or not, margins not crenulate-plicate, entire to denticulate or only plicate; raceme several-flowered, usually with $>6$ flowers, often much more

7. Leaves conspicuously shorter than the internodes, lip almost smooth, without conspicuous appendages, except by minute warts at the apical part of the axial veins

8. Leaves acuminate; lip $<41 \mathrm{~mm}$ long, subentire

8. Leaves obtuse to subacute, sometimes mucronate; lip $>60 \mathrm{~mm}$ long, trilobate at apex

V. phaeantha

7. Leaves usually as long or longer than the internodes, lip apex covered with papillae, retrorse trichomes or the veins thickened, wavy and complanate-warty

9. Lip fringed or denticulate at margins, with an apical thickening with warts, papillae, or retrorse appendages, flowers mostly whitish-green, weakly scented

10. Stems sulcate, minutely papillose, flowers large, the lip more than $65 \mathrm{~mm}$ long, margin long laciniate-fimbriate, midlobe covered by retrorse appendages up to $4 \mathrm{~mm}$ high

V. insignis

10. Stems non-sulcate, smooth, flowers smaller, the lip less than $65 \mathrm{~mm}$ long, margin laciniate, erose or denticulate, midlobe with few (less than 5) retrorse papillae or warty

11. Leaves ensiform, long acuminate; lip margin fimbriate

V. odorata

11. Leaves oblong to elliptic, acute or abruptly acuminate; lip margin undulate-denticulate, not fimbriate

V. planifolia

9. Lip entire or undulate at margins, without apical thickenings or if present without warts, papillae, or retrorse appendages, flowers mostly cream-yellow, with strong and spicy scent

12. Midlobe of the lip longer than wide, emarginate, flower bell-shaped, with the apex of the tepals reflexed

12. Midlobe of the lip broader than long, truncate to somewhat emarginate, flower trumpet-shaped, the apices of the tepals not reflexed 
13. Lip rhombic, with thickened, flat veins, leaves cuspidate

V. dressleri

13. Lip flabellate, obscurely trilobed, with a longitudinal, cushion-like thickening, leaves obtuse to acuminate 14

14. Stems $3-5 \mathrm{~mm}$ thick, leaves $10-22 \times 2.3-7.5 \mathrm{~cm}$; lip apex truncate, entire, ovary and sepals fairly papillose-verrucose

V. cribbiana

14. Stems $10-24 \mathrm{~mm}$ thick, leaves $22-29 \times 8-14 \mathrm{~cm}$; lip margin undulate, ovary and sepals smooth

TAXONOMIC TREATMENT

1. Vanilla calyculata Schltr., Repert. Spec. Nov. Regni Veg. Beih. 7: 42-43. 1920.

TYPE: Colombia, Cauca: $1000 \mathrm{~m}-$ M. Madero, not located; neotype (here designated): VALLE: Municipio de Tulúa, Corregimiento Mateguadua, Jardín Botánico, laderas en vía de repoblación natural. Altura $1100 \mathrm{~m}$. Enredadera; sépalos verde claro, pétalos amarillo claro, labelo amarillo intenso, frutos maduros color marrón; muy fragantes. 29 sept. 1984. W. Devia 815 holo. MO (3245054)!

Common nAmEs: "Vanilla"

Hemiepiphytic vine, branching, leafy, up to ca. 4 $\mathrm{m}$ high. Stems flexuose, terete, green, 6-12 mm thick; internodes $7-15.5 \mathrm{~cm}$ long. Aerial, free roots apparently subterete, pale brownish, up to $8.2 \mathrm{~cm}$ long, $2-3 \mathrm{~mm}$ thick. Leaves sessile to subpetiolate, the petiole up to 7-10 mm long; the blade oblong-lanceolate, rather narrow, the base rounded, the apex acute, coriaceousfleshy, apparently stiff and xerophytic, the margins slightly revolute, $7.5-21 \times 1.7-4 \mathrm{~cm}$. Inflorescence a 12-14-flowered receme, $4.2-6 \mathrm{~cm}$ long, rachis terete, green, ca. 4-6 mm thick. Bracts widely ovate, obtuse, green, concave, progressively smaller, up to $10 \times 6 \mathrm{~mm}$. Flowers opening successively, 2-3 open at once, pendant, bell-shaped, very showy, sepals pale green to yellowish green, petals pale yellow, lip deep yellow, ca. $9 \mathrm{~cm}$ long; strongly fragrant. Ovary terete, smooth, sulcate, the grroves twisted, ca. 4-4.5 $\mathrm{mm}$ long, $4 \mathrm{~mm}$ thick. Dorsal sepal oblanceolate to narrowly elliptic, apex subacute-obtuse, somewhat thickened, subcalyptrate, recurved, base attenuatesubunguiculate, basally canaliculate, convex above, smooth, ca. 12-13-veined, 66-80 x 8-17 mm. Lateral sepals oblong to narrowly elliptic, oblique, the lower margin more curved, apex subacute-obtuse, somewhat thickened, subcalyptrate, recurved, basally attenuatesubunguiculate, smooth, ca. 12-13-veined, 67-80 x 12-17 mm. Petals obliquely oblanceolate, lower margin more arcuate, apex attenuate, rounded, very attenuate at base, acute, with an axial, flat keel on the abaxial surface, $1 \mathrm{~mm}$ wide, ending in a free, conic, blunt, short, $1 \mathrm{~mm}$ long process; ca. 11-12-veined, $65-80 \times 9-16 \mathrm{~mm}$. Lip attached to the column along the margins of the basal half (ca. 41-46 mm), tubular, cymbiform, deeper near the middle; axially grooved on the abaxial surface, the groove well-defined and deep, when spread out $78-90 \times 36-45 \mathrm{~mm}$; long unguiculate, the claw apically rugose-papillose on the inner surface, $26 \times 3-3.8 \mathrm{~mm}$; the blade trilobed, ca. 36-veined, veins branched, the lateral lobes forming an inflated tube around the column, when flattened widely triangular-semiovate, margins entire, undulate near the midlobe, ca. $37-39 \times 14 \mathrm{~mm}$; midlobe dilated and recurved, approximately transversely oblong, deeply emarginate-bilobed, margins crenulate-undulate, veins conspicuously thickened, $14-16 \times 21-26 \mathrm{~mm}$; penicillate crest at ca. $41 \mathrm{~mm}$ from the base, $4.5 \mathrm{x}$ $3.8 \mathrm{~mm}$, made up by $8-10$ flabellate, shortly laceratelaciniate, retrorse, scales, some of them united to each other along the lateral margins; disc with progressively more thickened veins from the center to the apex of the lip, forming an apical, swollen, low cushion, obclavate in outline, rugose-papillose at the apex, 25-27 $\times 6 \mathrm{~mm}$, 2-3 mm high; with a group of transversal, yelloworange hairs at the basal part. Column very elongate and slender, subtrigonous-subclavate, slightly sigmoid, 51-55 mm long, ca. $4 \mathrm{~mm}$ wide; ventral surface flat and lanuginose at the distal half; apex dilated $(6 \mathrm{~mm}$ wide) with vertical wings, narrow, triangular-flabellate, undulate, ca. $4 \times 1 \mathrm{~mm}$. Stigma trilobed, the lobes emergent; rostellum trapezoid-flabellate, $2 \times 4.5 \mathrm{~mm}$; lateral lobes transversely oblong-flabellate, $1.2 \times 1.8$ $\mathrm{mm}$. Anther versatile, attached to the wide clinandrium margin by a broad filament, triangular-ovate, truncateemarginate, $5 \times 5 \mathrm{~mm}$. Fruit fragrant, $8-15 \mathrm{~cm}$ long, apparently thick and trigonous. Fig. 2, 17A. 


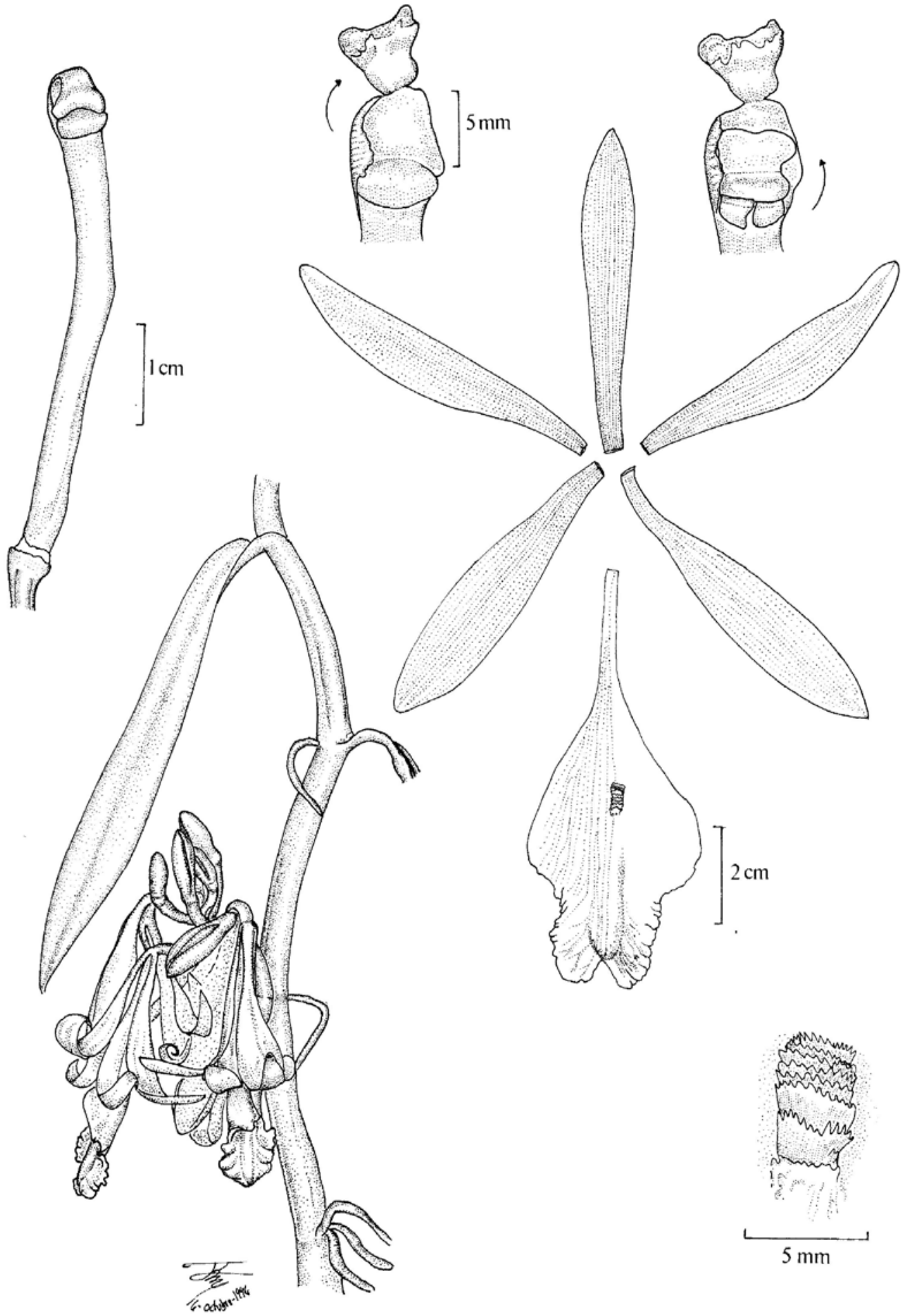

FIGURE 2. Vanilla calyculata Schltr. Based on published pictures (Hamer, 1981) and Devia 815. Drawing by R.

Jiménez. 
Distribution: Along the Pacific slope of El Salvador, Honduras, Costa Rica, and Colombia; a fruiting specimen from Michoacán, Mexico, may belong here. Ecology: Hemiepiphyte at relatively high altitudes (800-1300 m), often in rather dry places. Flowers recorded in April (El Salvador and Honduras) and September-February (Colombia).

The identity of $V$. calyculata has been obscure and no original specimens are known to us. However, Schlechter's description can be applied with confidence to the taxon above described and illustrated in Fig. 1. No other species known from Colombia $(V$. columbiana, V. dressleri, V. espondae, $V$. hostmanii, $V$. methonica, V. odorata, V. pompona, V. ribeiroi, and $V$. sprucei) agrees with the description of $V$. calyculata.

The specific epithet makes reference to the calyculus, a minute, cup-like structure sometimes distinguished in some vanillas and more developed in the species of the related genera Epistephium and Lecanorchis. The calyculus in $V$. calyculata is rather conspicuous when compared with other vanillas, and is more evident in pollinated ovaries that start to swell. Schlechter's description differs from our material of $V$. calyculata in the column described as glabrous instead of pubescent below the stigma (a trait found in all American penicillate Vanillas) and its smaller measurements of the perianth segments. We believe that Schlechter's description could had been based on a bud. However, the calyculus, the sessile, oblong, rather small leaves, the deeply excised midlobe of lip, the pubescent lip claw, the 3-5 thickened midveins on the disc, the unusually high altitude for a Vanilla and its strong resemblance with the Brazilan V. chamissonis (its sister species, Soto unpublished) suggest that the name $V$. calyculata may be applied to this taxon with confidence.

Vanilla calyculata is distinguished from $V$. chamissonis by its larger, bell-shaped, pendant, yellowish flowers with revolute, flaring tepals, and the longer midlobe of the lip.

Despite its unique characters, specimens of $V$. calyculata have been regarded by Reichenbach and Rolfe (1896; e.g. Lehmann 2263) as V. pompona. Later it was reported from El Salvador (Hamer, 1974) as $V$. phaeantha Rchb.f. José Linares, from Escuela Agrícola Panamericana has told us that this species is abundant, well-known, and usually confused with $V$. pompona in the dry valleys of central Honduras.
The specimen O. Pank sub F. Hamer 203 bears peloric flowers where the column has two anthers and two very odd stigmas.

Other ReCords: EL SALVADOR: La Palma-Finca El Refugio, río Nanuapa, $1000 \mathrm{~m}$ alt., terr. climbing oaks or manzana rosa, collected 3.4.1969. April 11 1969, O. Pank $y$ F. Hamer 203 AMES $(* 112862 ; * 113837)$ ! HONDURAS: COMAYAGUA: Fruit triangular, up to 6 in. long. Climbing in shrubs, thicket along river, plain near Sihuatepeque. 1050 $\mathrm{m}$ altitude. 7/23/36, T.G. Yuncker, R.F. Dawson \& H.R. Youse $6045 * \operatorname{AMES}(46667)$ ! G! K! *MO(1115382)! NY! MORAZAN: flores cremas, bejuco sobre arbustos. Aguas abajo de la Quebrada de Sta. Clara. Alt. 850 m, Abril 28, 1948, A. Molina $808 * \mathrm{~F}(1676153)$ ! Bejuco, creciendo sobre rocas y arbustos, flores amarillentas algo fragantes (por la tarde). Quebrada Santa Clara, ca. $2 \mathrm{~km}$ al norte del Zamorano, alt. 800 m. Mpio de San Antonio de Oriente. 19 de junio de 1996. J. L. Linares 3386 MEXU! El PARAISO: Mpio. Morocelí, Quebrada El Cajocote conocida también como El Terrero, $8.7 \mathrm{~km}$ al $\mathrm{N}$ de Morocelí, por el camino a Mata de Plátano. Veg. riparia, veg. circundante selva baja caducifolia y bosque de pino-encino, $14^{\circ} 10^{\prime} 10^{\prime \prime} \mathrm{N}$, $86^{\circ} 51^{\prime} 06^{\prime \prime} \mathrm{W}, 680 \mathrm{~m}$. Bejuco creciendo sobre Guettarda macrosperma, flores amarillo pálido con el ápice amarillo oro, olor suave y dulce, 29 abril 2004, J. L. Linares 7313 MEXU! [cf., sterile] "Vainilla", trepadora sobre árboles y matorrales, de Barranco de las Mesas, Alt. 900 m, Agosto 1, 1957, L.O. Williams \& A. Molina 8575 F(1590341)! Open savannah, Las Mesas region near Yuscarán. August, 1960, H.W. Pfeifer 1454 *US(2563382)! COLOMBIA: TOLIMA: Fingerdick, bis $5 \mathrm{~m}$ lang. Bl. dickfleischig \& dunkelgrün. Blt. grünlich meist mit heller Lippe. Früchte bis $8 \mathrm{~cm}$ lang. Auf Bäumen in Zavannen -Wäldern bei La Plata. 800-1500 m. 3.12.1882. F.C. Lehmann 2263 BM! G! Vanilla, white and red inside, cultivated E. Dryander 2379 BM! "Columbien" Lehmann W(59043, in part, the flower and probably the right shoot)!

The following sterile specimens may belong here: MEXICO: MICHOACAN: Hacienda de Coahuayula, Feb. 1901, G.M. Emrick 16 F(95476)! COLOMBIA: [cf., leaves atypically broad] TOLIMA: La Plata, 1000-1300, *Lehmann 6278 AMES(14875)!

\section{Vanilla costaricensis Soto Arenas, sp. nov.}

TYPE: COSTA RICA: ALAJUELA: Llanura de San Carlos. Alt. 200 m., Feb. 20, 1966. Lip white, tepals same green as leaves; vine. Lowland rain forest between Los Chiles and Venecia. A. Molina R., L.O. Williams, W.C. Burger and B. Wallenta 17565, holo. CR(062310)! iso. $\mathrm{MO}(2367689)$ ! 
Species Vanillae oroanae similis floribus minoribus, labello integro breviore differt.

Hemiepiphytic vine, leafy. Stems keeled, $8 \mathrm{~mm}$ thick (in dried condition); internodes ca. $12.5 \mathrm{~cm}$ long. Aerial, free roots dorsiventraly compressed, pale brownish, ca. $2.5 \mathrm{~mm}$ wide. Leaves petiolate, the petiole canaliculate, ca. $17 \mathrm{~mm}$ long, $9 \mathrm{~mm}$ wide; blade elliptic, abruptly mucronate, base acute to attenuate, green, membranaceous (in dried condition), 21-22 x $8.7-9.5 \mathrm{~cm}$. Inflorescence similar to the vegetative shoots, but smaller, elongate, a 3-4-flowered raceme (probably longer and more floriferous when completely developed), 28-32 cm long, internodes up to $6 \mathrm{~cm}$ long; peduncle $15-23 \mathrm{~cm}$, rachis ca. $3 \mathrm{~mm}$ thick. Bracts foliaceous, subpetiolate, the petiole ca. $3 \mathrm{~mm}$ long; blade elliptic, acute-acuminate, base obtuse-rounded, membranaceous, 2.9-7.3 x 1.6-3.4 cm. Flowers successive, 2 open at once, with spreading segments, ca. $3.5 \mathrm{~cm}$ in diameter; tepals green, lip white. Ovary rather sigmoid, $34-40 \times 3.5 \mathrm{~mm}$. Dorsal sepal strongly twisted and the margins contorted-widely undulate, elliptic, apex acute, rounded, base cuneate, ca. 10 veined, smooth, $41 \times 11 \mathrm{~mm}$. Lateral sepals narrowly elliptic, acute-subacute, base obtuse, margins undulate, reflexed, smooth, ca. 10 veined, $41 \times 10.5 \mathrm{~mm}$. Petals narrowly elliptic, apex truncate, notched, base widely cuneate, strongly twisted, widely undulate-contorted, with the lateral margins reflexed, difficult to spread out without distortion, ca. 10 veined, $35.5 \times 9 \mathrm{~mm}$. Lip attached to the column less than $2 \mathrm{~mm}$, slightly arcuate, almost straight, with the lateral margins erect forming a throat around the column, quadrate-flabellate, entire, apex truncate, obcurely trilobed, the lateral lobes as long as the midlobe, or slightly longer, base roundedtruncate, the apical margin entire to dentate, ca. 26 veined; $24-27$ x 20-21 mm; callus made up of a pair of flat, broad keels along the axial line, from the base to the begining of the apical third, then separated in 3 low, erect, congested keels ending at the apex; additional lateral keels with complanate warts adorn the basal half. Column relatively short, straight to very slightly arcuate, semiterete, with a dilated apex, $16 \mathrm{~mm}$ long; smooth, except by the callus of verrucose keels at base, ca. $5 \mathrm{~mm}$ long; vertical wings flabellate, ca. $1.5 \times 3 \mathrm{~mm}$. Stigma lobed, the midlobe, convex, very prominent, almost perpendicular to the column axis, ca. $2 \times 1.5$ $\mathrm{mm}$; lateral lobes much smaller, fused in an ovate- subquadrate, emergent blade, ca. $0.5 \mathrm{~mm}$ long. Anther galeate, protruding at apex, laterally compressed, $4 \mathrm{~mm}$ long, with a long, thick filament $1.2 \mathrm{~mm}$ long. Fig. 3 .

Distribution: Known only from northern Costa Rica. Ecology: In lowland rain forest at $200 \mathrm{~m}$ altitude; flowering in February.

This species is known only from the type locality and it has been misidentified as V. mexicana Miller, a different, closely related species from the West Indies and northeastern South America. Vanilla mexicana has a distinctly trilobed lip, with the apex of the lateral lobes slightly above the middle of the lip; in $V$. costaricensis the lip is entire, flabellate, with the apex truncate and just obscurely trilobed, but the lateral lobes of the apex are subequal or slightly longer than the midlobe; additionally, the keels at the apex of the lip in V. mexicana are much more conspicuous. Vanilla costaricensis has large bracts similar to those of $V$. inodora Schiede, easily distinguished by the cushionlike, axial callus on the lip. Also closely related are $V$. guianensis and $V$. martinezii with much larger flowers, straight sepals, more rugose keels, and shorter inflorescence, with reduced bracts. The species was illustrated by Dr. Rafael Lucas Rodríguez (Rodríguez C. et al., 1986) based on a specimen that has not been located.

The closest relative of Vanilla costaricensis is $V$. oroana Dodson of Ecuador. They have similar inflorescences and flower morphology, with the column almost identical. However, $V$. oroana has a longer, relatively narrower, trilobed non-truncate lip, and the surface of the lateral, basal part is minute, but conspicuously more sculptured than in $V$. costaricensis. Vanilla oroana flowers are in general much larger.

In the examined material of $V$. costaricensis (and also $V$. oroana) the lateral lobes of the stigma are fused to each other to form an ovate-subquadrate, emergent blade. This is notoriously different from the concave stigma found in other membranaceous (e.g. V. inodora). However, observation of this trait is difficult because of the poor preservation of the column, and the large amount of sticky substance in the stigmatic area, visible in fresh material but absent in pressed specimens.

OTHER RECORDS: COSTA RICA: ALAJUELA: Llanura de San Carlos. Alt. 200 m., Feb. 20, 1966. Lip white, tepals same green as leaves; vine. Lowland rain forest between Los Chiles and Venecia. A. Molina R., L.O. Williams, 

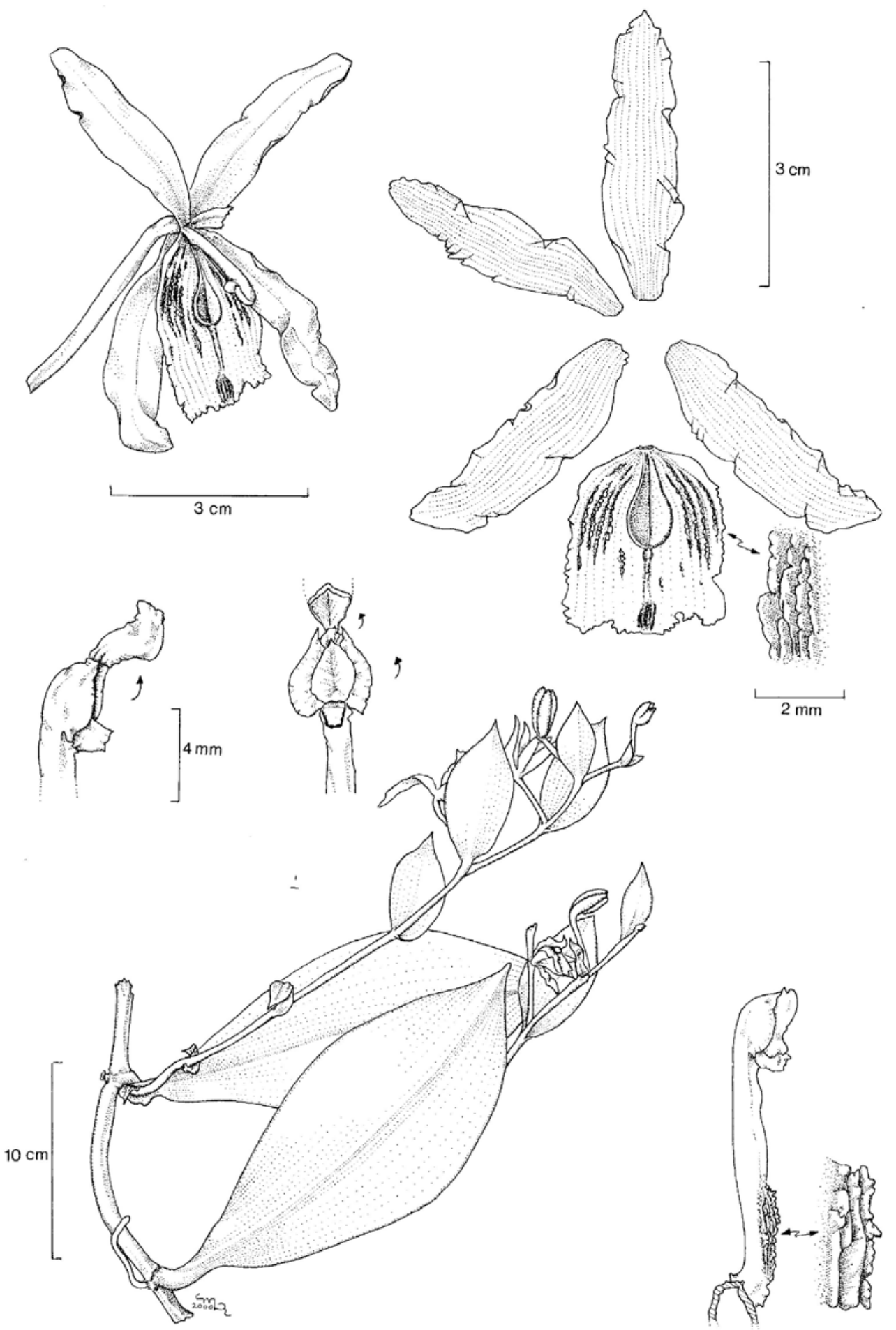

FiguRE 3. Vanilla costaricensis Soto Arenas. Based on A. Molina et al. 17565, except floral dissection and column based on A. Molina et al. 17567. Drawing by M. López. 
W.C. Burger and B. Wallenta 17567 *SEL(016793)! *F(1771938)!

\section{Vanilla cribbiana Soto Arenas, sp. nov.}

TYPE: MEXICO: CHIAPAS: Mpio. Ocosingo: Estación de Biología Chajul, en el borde del Río Lacatúm; a $680 \mathrm{~m}$ del Puente Hamaca, por la vereda a Arroyo Miranda, ca. 180 m s.n.m., selva alta perennifolia en plano, ca. $8 \mathrm{~m}$ de alto, flores con tépalos blanco-cremosos, sépalos verdosos en la superficie externa, labelo atrompetado, amarillo intenso con rayas anaranjadas en las venas, labelo extendido y truncado, sin papilas, no deflexo en el ápice, flores bien abiertas. Fragancia muy intensa y conspicua, a mentol y cítrico. Ovario verdeblanquecino con papilas. 20 junio 1996, M. Soto 7945 y R. Solano, holo. *AMO!; iso. K !, AMO (in spirit)!

Vanillae hostmanii primo adspectu similis, sed foliis minoribus, inflorescentiis minoribus paucifloribus, labello obscure 3-lobato, lobo medio distincto, subquadrato, quinque nervis papillosis incrassatis in centro apice ornato versus circa decem nervos in lobos laterales extensos

\section{COMmON NAMES: "Vainilla".}

Hemiepiphytic vine, somewhat branching, leafy, up to $12 \mathrm{~m}$ high. Stems terete, smooth, green, 3-5 mm thick; internodes 3-9 cm long. Aerial, free roots pale subterete, brownish, ca. $2 \mathrm{~mm}$ thick; attaching, aerial roots conspicuously dorsiventrally compressed, 2-5 $\mathrm{mm}$ wide. Leaves subpetiolate, petiole $1-1.5 \mathrm{~cm}$ long; blade obliquely elliptic to elliptic-oblong, abruptely acuminate-apiculate, stiff, brittle, $10-22 \times 2.3-7.5 \mathrm{~cm}$. Inflorescence a ca. 10-flowered raceme (rarely up to 30 flowers), 30-37(-110) mm long, rachis 18-22(95) $\mathrm{mm}$ long, $4 \mathrm{~mm}$ thick. Bracts ovate-triangular, obtuse, very concave, progressively smaller towards the apex, up to $8 \times 4 \mathrm{~mm}$. Flowers successive, 2-3 open at once, with spreading segments, apparently ephemeral, very showy, white-cream tepals, sepals externally cream-greenish, lip deep yellow with orange stripes, ca. $8 \mathrm{~cm}$ diameter; fragrance strong, mentholate and citric, similar to that of $V$. pompona. Ovary arcuate, dorsiventrally slightly compressed, thickened at the very base, whitish-green, conspicuously papillose, more densely towards the perianth, sulcate, the grooves twisted, 44-46 mm long, 4-5.5 mm thick. Dorsal sepal narrowly elliptic, apex subacute-rounded, subcalyptrate, minutely apiculate, base attenuate, flat, apically concave, 9-veined, minutely papillose on the abaxial surface, the papillae in longitudinal rows and forming transverse, undulate rows, very fleshy and stiff; $63-65$ x 12.5-13.5 mm. Lateral sepals obliquely oblong-elliptic (upper margin curved, lower margin more straight), apex subacute-rounded, subcalyptrate, base attenuate, canaliculate basally, slightly convex, apically concave, apex somewhat recurved, margins conspicuously involute, ca. 12-14-veined, minutely papillose in the abaxial surface, the papillae in longitudinal rows and forming transverse, undulate rows, very fleshy and stiff; $60-65 \times 12.5-14 \mathrm{~mm}$. Petals oblanceolate, very slightly oblique (the lower margin more straight), slightly arcuate, apex obtuse, widely rounded, somewhat thickened at apex, base attenuate, basally canaliculate, slightly concave towards the apex, with an elevated, axial, flat keel on the dorsal surface, ending in a long triangular, flat, free (ca. $2 \mathrm{~mm}$ ) process; dorsal surface conspicuously canaliculate apically, surface colliculate, the cells in longitudinal rows, 14-veined; with granular, threadlike, somewhat branched inclusions; $64 \times 12.5-13.5$ $\mathrm{mm}$. Lip attached to the column along the margins of the basal half (ca. $28 \mathrm{~mm}$ ), tubular, trumpedshaped, cymbiform, deepest near the middle; axially grooved on the abaxial surface; when spread out 50$52 \times 38 \mathrm{~mm}$; unguiculate, claw with 4 obscure bands of unicelluar, minute, elongate, yellow-brownish, trichomes; the blade obscurely flabellate, trilobed, margin conspicuously entire, subtruncate, lip with inclusions similar to those found in the petals; lateral lobes widely and obliquely triangular, overlapping above the column, $33 \times 16 \mathrm{~mm}$; midlobe small, subquadrate-ovate, slightly deflexed, smooth, the apex flat, ca. $8.5 \times 14 \mathrm{~mm}$; penicillate callus made up by ca. 10 congested, retrorse, trapezoidal, laciniate scales, the scales sometimes united to each other along the lateral margins, ca. $5 \times 4 \mathrm{~mm}$; the region just after the penicillate callus, smooth, with denser inclusions; with 5 low, rugose, rounded, densely papillose keels confluent in an apical cushion-like thickening, 4-6 secondary, more inconspicuous keels, shorter, not reaching the apex. Column elongate, $34 \mathrm{~mm}$ long, 


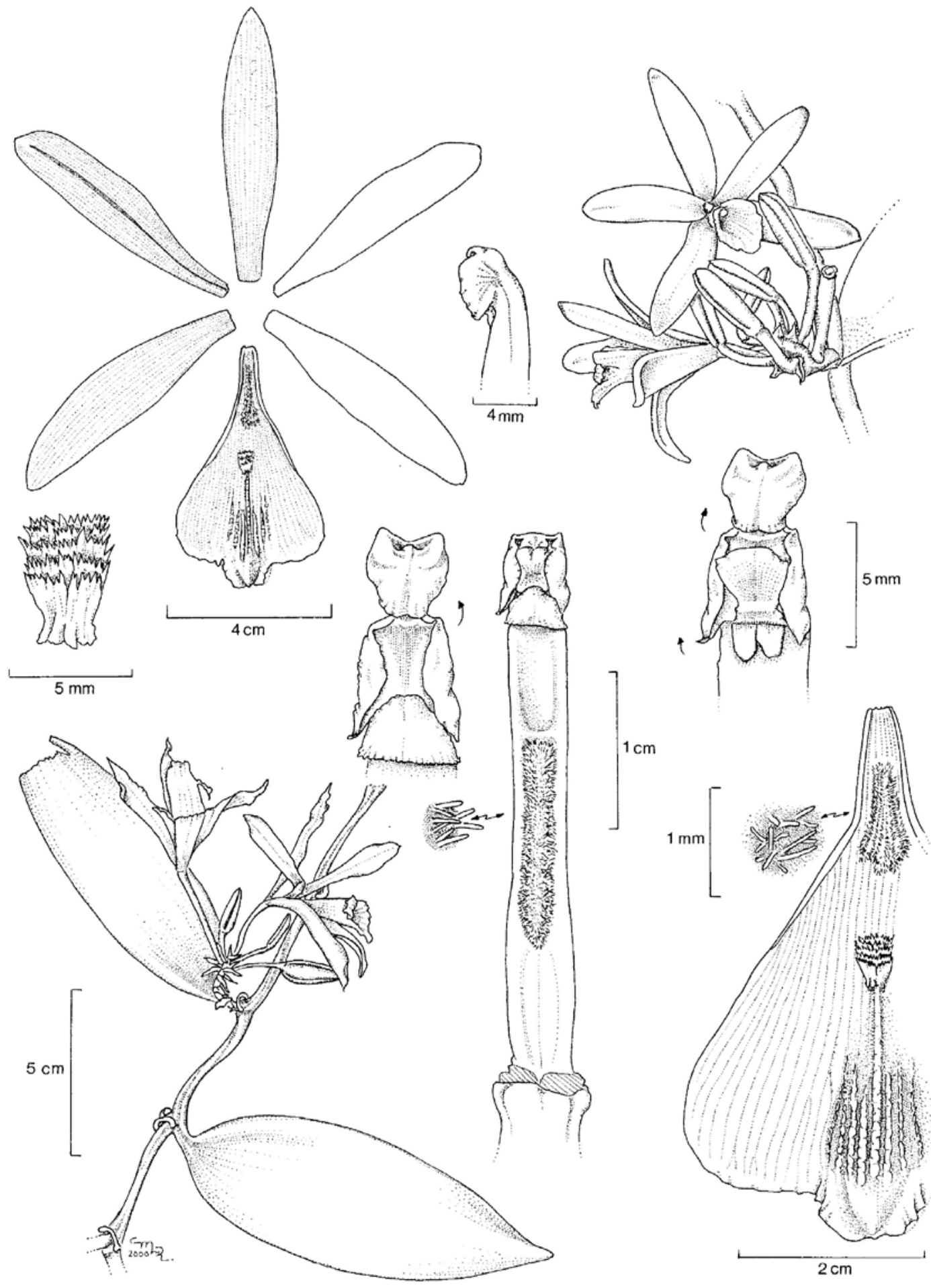

FiguRE 4. Vanilla cribbiana Soto Arenas. Based on M. Soto 7945. Drawing by M. López. 
$3 \mathrm{~mm}$ wide; ventral surface pubescent-lanuginose at the middle, hairs yellowish; apex dilated, $4 \mathrm{~mm}$ wide; vertical wings trapezoidal, the lower margin projected and acute, ca. $2 \times 4.3 \mathrm{~mm}$. Stigma trilobed, the lobes emergent, with a membranaceous, convex rostellum, $4 \mathrm{~mm}$ wide; lateral lobes subquadrate, rounded, ca. $1.2 \times 1.2 \mathrm{~mm}$. Anther versatile, articulate to the wide, convex, clinandrium, ovoid-subquadrate, $3.5 \times 3 \mathrm{~mm}$. Fruit short, thick, trigonous in cross section, $10-16 \mathrm{~cm}$ long, 1-1.4 cm thick; fragrant when ripe, aroma similar to common vanilla, but weaker. Fig. 4, 16A.

Distribution: Known from Mexico (Oaxaca and Chiapas), Guatemala, Belize and Honduras.

ECOLOGY: Hemiepiphyte in rain forest on soils with variable drainage in areas with $2500-4000 \mathrm{~mm}$ of rainfall, at $150-350 \mathrm{~m}$ altitude. It is the most common Vanilla in many areas with tropical rainforest of the Selva Lacandona (Chiapas) and the Petén (Guatemala). It is the only penicillate Vanilla in N Central America blooming during the rainy season, in July and August.

Vanilla cribbiana is a member of the $V$. hostmanii group. Like the other members of this complex, it has a slightly trilobed to subentire lip with a disc adorned by some thickened veins. It is different from $V$. hostmanii Lindl. from Amazonia, probably its closest relative, by its smaller leaves, shorter inflorescence with fewer flowers, more defined and subquadrate midlobe of the lip, and only ca. 5 thickened, papillose veins in the center of lip apex, not ca. 10 and spreading to the lateral lobes. From Vanilla dressleri Soto Arenas from Costa Rica to Colombia, it is distinguished by its denser raceme, more defined apical lobe of the lip, less conspicuous thickened veins on the disc, papillose-granulose outer surface of the sepals and broader, thicker leaves. Vanilla ruiziana Klotzch (synonym $V$. weberbaueriana Kraenzl.) from Peru and Bolivia has a larger, ovate midlobe of the lip which bears 1-3 elevated, axial keels near the apex and the tepals are acute and the sepals neatly calyptrate. The flowering period is July-August, at the beginning of the rainy season, anf it is also distinct. Vegetatively it is easily confused with $V$. planifolia but the leaves of $V$. cribbiana are usually more elliptic, basally more attenuate, and acuminate at the apex. However, the vegetative differences are difficult to appreciate, and both species are easily confused if flowers are not available, and especially in sterile shoots grown in shade. Therefore, Vanilla cribbiana has been confused with $V$. planifolia, and also with $V$. pompona and even $V$. inodora, in the herbaria and in the plantations.

The fruits of this species are fragrant, and probably of some potential commercial interest, but the vine is not a strong grower, nor does it flower freely, at least in the plantations of northern Oaxaca, where it was introduced when confused with $V$. planifolia (Pérez Mesa, pers. com.). It is pollinated by an unidentified Eulaema bee. Beza (com. pers.) reports that the fruits of this species have been cured in Guatemala.

Other ReCORDS: MEXICO: OAXACA: cultivated by J. Pérez Mesa at Instituto Tecnológico Agropecuario \# 3, San Bartolo Tuxtepec, from plantation in Jaltepec de Condoyoc, near Ma. Lombardo, 24-IV-1997, J. Pérez sub M. Soto 8504 AMO(in spirit)! CHIAPAS: Mpio. Ocosingo, Estación de Biología Chajul, ca. 200 m s.n.m., selva alta perennifolia después de la sabana II, 19 junio 1996, M Soto 7941 \& R.Solano *AMO(sterile)! Chajul, Camino a Arroyo Miranda. Fruto trígono, ca. $16 \mathrm{~cm}$ de largo, 14 $\mathrm{mm}$ de grosor, amarillo, rugoso, inflorescencia con ca. 21 flores, 22 junio 1996, S. Sinaca sub M. Soto 7953A MEXU! Mpio.Ocosingo, Estación de Biología de Chajul, camino a la Sabana I, selva alta perennifolia en loma, ca. $230 \mathrm{~m}$ s.n.m. 13-IV-1997, M. Soto 8387 *AMO(sterile)! Mpio Ocosingo, $1.5-2 \mathrm{~km}$ al SW de la Colonia Benito Juárez Miramar, sobre la desviación a Tierra y Libertad. Acahual de 18 años derivado de selva alta perennifolia, con Bursera simaruba, Vochysia hondurensis, $360 \mathrm{~m}$ s.n.m., $20^{\circ} \mathrm{N}$,

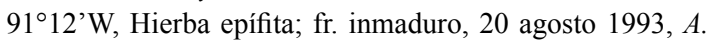
Reyes-García y M. Sousa 2029 MEXU(584270, 584313)! Mpio. Ocosingo, entre Bonampak y el Río Lacanjá, selva alta perennifolia con Dialium guianense, Brosimun spp., Ficus glabrata y Terminalia amazonia, 300-350 m s.n.m., abril 2000, M. Soto 9617, S. Maldonado, P. Schlütter, L. López AMO(sterile)! [cf., fruit apparently sulcate] a $2 \mathrm{~km}$ del Crucero Corozal, camino Palenque-Boca de Lacantúm, Mpio. Ocosingo, $180 \mathrm{~m}$ s.n.m., hierba epífita, fruto verde, selva alta subperennifolia, 13 feb 1985, E. Martínez 10299 MEXU! Mpio de Ocosingo, carretera Palenque-Marquéz de Comillas, Crucero San Javier; selva alta-mediana subperennifolia, inundable, perturbada con Chrysophylla, Vochysia y muchas epífitas, 16-IV-1997, M. Soto 8438-8440 AMO(sterile)! GUATEMALA: PETEN: Fleshy epiphytic vine. Canchacán, in high rain forest of southeastern Petén. July 14 1959. C.L. Lundell 16457 *LL(x2, buds)! $\mathrm{MO}(3832548)$ ! "Vianilla", vine, fruits black, fragrant, Dolores, in low forest of pinal about $800 \mathrm{~m}$ south of the village on the Machaquila Road, May 18, 1961, E. Contreras 2333 MEXU(511605)! NY! LL(fruit)! LL(buds)! 
"Vainilla" Fleshy vine, fruit green; Dolores, on Río Mopan trail, in high forest, October 17, 1961, E. Contreras 3063 LL(fruit)! BELIZE: STANN CREEK: "vainilla". Vine; fls., yellow. In high ridge on hill top. Middlesex, 2 July 1939. P.H. Gentle 2894 *AMES(58082)! K! LL! NY! TOLEDO: Jimmy cut, Alt. $40 \mathrm{~m}$, vive, hanging from tree, no flowering or fruiting, stiff, thick leaves, 1973, C. Whitefoord 1816 BM! HONDURAS: ATLANTIDA: Near Tela. Guaymas. Clambering over tree. March 17, 1923 O. Ames II 211 $\operatorname{AMES}(36945$, fruit)!

\section{Vanilla dressleri Soto Arenas, sp. nov.}

TYPE: PANAMA. COLON: End of Pipeline road on Río Agua Salud, 9-10 mi N of Gamboa. Tropical wet forest. Elev. 20-50 m. Vine. Flowers greenishyellow, lower lip white. Column yellow. Sweet smelling, 15 April 1982, S. Knapp $4621 \&$ J. Mallet (holo. MO 3032052!).

Species Vanillae hostmanii similis sed floribus longioribus, labello longiore subintegro anguste obtuso differt.

Hemiepiphytic vine, leafy. Stems flexuoue, apparently terete, grooved, 3-4 $\mathrm{mm}$ thick (in dried specimens); internodes $7.5-11.5 \mathrm{~cm}$ long. Aerial, free roots terete, $2 \mathrm{~mm}$ thick; attaching, aerial roots strongly flattened, up to $4 \mathrm{~mm}$ wide. Leaves petiolate, the petiole canaliculate, 11-18 $\mathrm{mm}$ long, ca. $5 \mathrm{~mm}$ wide; the blade oblanceolate, obovate to narrowly elliptic, much larger than the internodes, sometimes slightly oblique, basally rounded to attenuate, apex acuminatecuspidate, fleshy, chartaceous (in dried specimens), mesophytic, conspicuously pendant in living condition, 10.5-21.5 x 3.0-6.5 cm. Inflorescence a 3-10 flowered raceme, rather lax, contiguous bracts distant up to 11 $\mathrm{mm}$; peduncle $15-35 \mathrm{~mm}$ long, rachis $15-43 \mathrm{~mm}$ long, at least $4 \mathrm{~mm}$ thick. Floral bracts patent, spreading, concave, widely ovate to elliptic, obtuse, up to $14 \mathrm{x}$ $8 \mathrm{~mm}$. Flowers successive, 1 open at a time, big and showy, tepals white to greenish-yellow, lip orangeyellow in the inner surface, fading to white, with brownish veins, column yellow; fragrance clove-like. Ovary subterete, straight, thickened towards the apex, bisulcate, the grooves twisted, very inconspicuously and minutely papillose, $42 \mathrm{~mm}$ long, 4-5 mm thick; sometimes slightly calyculate. Dorsal sepal linear to narrowly elliptic, apex obtuse, rounded, subcalyptrate, thickened, with 2-3 warts at the apex of the outer surface; base narrowed, canaliculate; conspicuously keeled on the outer surface, blade apparently somewhat concave, ca. 13-veined, stiff, fleshy, $72 \mathrm{x}$ $11.5 \mathrm{~mm}$. Lateral sepals obliquely linear to narrowly elliptic, apex obtuse, rounded, calyptrate, thickened, inconspicuously warty at the apex on the outer surface, base narrowed, concave, blade ca. 11-veined; obscurely keeled on the outer surface, stiff, fleshy, $67 \times 12 \mathrm{~mm}$. Petals linear to narrowly elliptic, slightly oblique, apex widely rounded, base narrowed, basally concave, with an elevated, axial, flat keel on the outer surface, the keel ending in an acuminate, laterally compressed process, ca. $2 \mathrm{~mm}$ long, apex strongly grooved, ca. 10 veined; $68 \times 13.5 \mathrm{~mm}$. Lip attached to the column along the margins of the basal half (ca. $28 \mathrm{~mm}$ ), tubular, apparently concave, axially grooved on the abaxial surface; when spread out $65 \times 39 \mathrm{~mm}$; unguiculate, the claw canaliculate, lanuginose becoming pubescent towards the blade, $15 \mathrm{~mm}$ long, $5 \mathrm{~mm}$ wide near the blade; blade subrhombic, margin undulate, pleated, apex obtuse-rounded, very slightly notched, ca. 24-veined; the ca. 11 veins of the apical part thickened and rather warty, with the warts flattened, the central ones rather elevated; the region corresponding to the lateral lobes ca. $36 \times 15 \mathrm{~mm}$; the wanting midlobe $10 \mathrm{x}$ $15 \mathrm{~mm}$; penicillate callus at $28 \mathrm{~mm}$ from the lip base, made up by ca. 12, obtriangular, basally long attenuate, fimbriate scales, $5 \times 2.5 \mathrm{~mm}$. Column elongate, rather straight, ca. $34 \mathrm{~mm}$ long, $3 \mathrm{~mm}$ wide; densely pilose on apical $2 / 3$ of the ventral surface, below the stigma; apex dilated, vertical wings oblong, lower apex acute, ca. 1.5 $x 3 \mathrm{~mm}$. Stigma trilobed, the lobes emergent, rostellum strongly convex, lateral ones apparently very narrow. Fig. 5, 16B.

Distribution: Known from Costa Rica, Panama and Colombia.

ECOLOGY: In lowland to submontane (20-1000 m), wet forest. Flowering from March to early June. The species seem to be fairly common, at least in the Río Savagre area of W Costa Rica. The clove-scented flowers suggest a male euglossine bee as pollinator.

Etymology: Dedicated to Dr. Robert L. Dressler, authority in orchid evolutionary biology and in orchid floristics of Central America.

This large-flowered species is a member of the $V$. hostmanii group, characterized by its large flowers with 


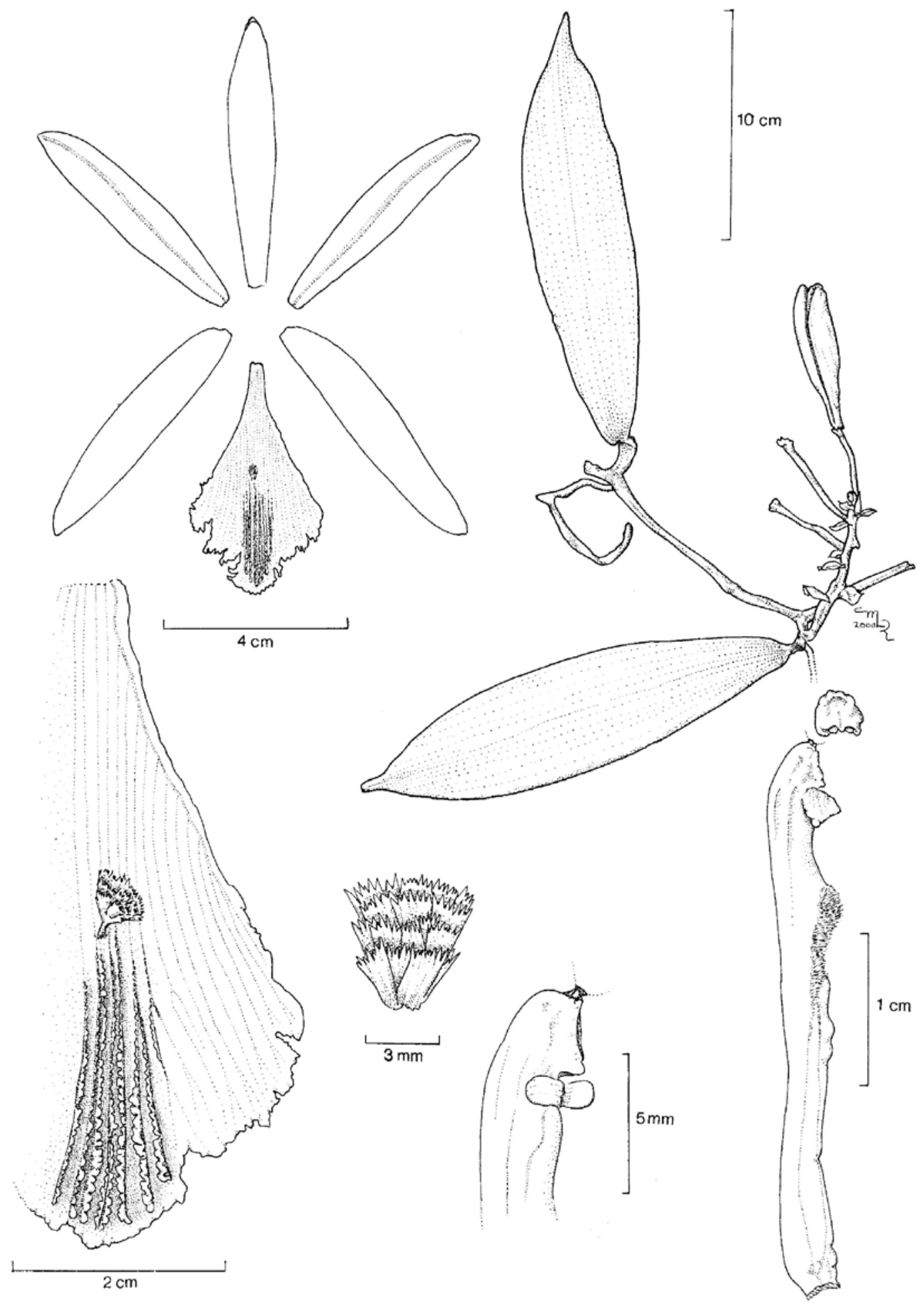

Figure 5. Vanilla dressleri Soto Arenas. Based on G. McPherson 9196. Drawing by M. López. 
scarcely trilobed lips, granulose ovaries and sepals, and the distal veins of the disc thickened. Among the group, it is distinguished by the rather lax inflorescence, with the flowers distant (ca. $1 \mathrm{~cm}$ ), patent bracts, subentire lip, with the blade subrhombic in outline, and very scarcely pappilose sepals; the other members of the group, $V$. cribbiana, $V$. hostmanii and $V$. ruiziana have conspicuously granulose sepals. From $V$. cribbiana it is additionally distinguished by the narrower, thinner leaves which are more long acuminate-cuspidate, more lax inflorescence, less defined apical lobe, veins of the disc more conspicuously thickened, and flowering time mostly in March-May, not in July-August. Vanilla hostmanii from Amazonia has very long inflorescences that bear many more flowers (e.g. 40-50) and the leaves are larger, thicker, but not as strongly acuminate-cuspidate. Vanilla ruiziana, from Peru and Bolivia has larger, broader, less acuminate-cuspidate, and thicker leaves, but is similar to $V$. dressleri in having rather elevated axial keels of the lip. Vanilla gardneri from Brazil has a subacute lip apex and oblong leaves, not cuspidate.

Central American specimens of $V$. dressleri have been previously identified as $V$. planifolia and $V$. insignis, distantly related species, easily separated by the distinctly trilobed lips with well developed retrorse warts.

Other RECORdS: PANAMA: Flowers yellow green; lip yellow with green patch at apex. Collector, N.H. Williams, Rio Iguanita, fl in cult, 14 April 1978, SEL 56-76-11[accession num.], *A. Pridgeon s.n. SEL(019244; the leaves; flowers may belong to $V$. phaeantha)! COLON: Santa Rita Ridge, southeast of Colón, c. $9^{\circ} 20^{\prime} \mathrm{N}, 79^{\circ} 45^{\prime} \mathrm{W}$. Along ridge road, 10-12 miles from Transisthmian Highway, c. $550 \mathrm{~m}$. Vine; perianth white, the lip orangeyellow within basally; flower clove-scented. 21 May 1986. G. McPherson 9196, holo. MO(3432756)! COCLE: Huge plant purchased in the El Valle market. Flowers pale yellowgreen. 6 March 1976. R.L. Dressler, C. Luer, J. Luer \& P. Taylor 768 *SEL(009187)! COSTA RICA: ALAJUELA: Reserva Biológica Monteverde, Río Peñas Blancas, $10^{\circ} 19^{\prime} \mathrm{N}, 84^{\circ} 43^{\prime} \mathrm{W}, 900 \mathrm{~m}$. Epífita. Flores blancas con amarillo. 7 June 1988. W. Haber 8471 \& E. Cruz CR INB! MO(3714711)! Reserva Monteverde, Río Peñas Blancas, $10^{\circ} 20^{\prime} \mathrm{N} 84^{\circ} 43^{\prime} \mathrm{W}, 820 \mathrm{~m}$. Bejuco. Flores blancas. 10 June 1987. W. Haber 7423 \& E. Cruz INB! Upala, San José, Villa Nueva, $11 \mathrm{~km}$ al noreste de San José. $10^{\circ} 59^{\prime} \mathrm{N}, 85^{\circ} 07^{\prime} \mathrm{W}$, $40 \mathrm{~m}$. Terrestre, trepadora, escandente. Flores en botón verde amarillento. 18 April $1988, * G$. Herrera 1840 CR MO(3864177)! CARTAGO: $12 \mathrm{~km} \mathrm{~S}$ of Turrialba by air, 4 $\mathrm{km}$ SE of Pejibaye along Río Gato. Disturbed primary forest along river. Vine. $700 \mathrm{~m}$ alt. $9^{\circ} 48^{\prime} \mathrm{N}, 83^{\circ} 42^{\prime} \mathrm{W}$. Vine. $16-17$ April 1983, *R. Liesner 14435 MO(3102177)! SAN JOSE: Sepals and petals greenish yellow. Lip cream-colored with greenish-brown raised lines. Callus in middle of lip raised and with rows of attached hairs or brushes. Vine. Parque Nacional Braulio Carrillo; Carrillo station, 300-600 m, 31 May-5 June $1980,{ }^{*}$ C. Todzia 1291 LL! HEREDIA: Sep $\&$ pet interiorly creamy, faintly greenish, lip embraces column loosly, interior of lip and base yellow, apical 3rd fading to white, leaves suculent, stems single, not branched. Sarapiquí: (April) .... The lip has been apressed .., do not reveal the actual appearence of the flowers at complete anthesis, and they have no perceptible odour at 10:30 a.m. Flowers in axillary, stubby branches of from 5 to 8 flowers. Leaves drooping apparently from a rather slender stem, April 1959, * C.H. Lankester 1746 SEL (011365)!. LIMON: Reserva Biológica Hitoy Cerere, Valle de la Estrella. Bosque primario, bosque secundario. $700 \mathrm{~m}$ Epífita, flores amarillas con blanco, 4 December 1990, G. Carballo 325 INB! PUNTARENAS: Cantón de Golfito. P.N. Corcovado. Valle de Coto Colorado. Estación Esquinas: Sección Esquinas. $08^{\circ} 46^{\prime} 00^{\prime \prime} \mathrm{N} 83^{\circ} 15^{\prime} 00^{\prime \prime} \mathrm{W}, 100 \mathrm{~m}$. Bejuco, frutos verdes. 17 July 1993, M. Segura 121, F. Quesada \& R. Aguilar INB! COLOMBIA: VALLE: Río Calima (región del Chocó); La Trojita, 5-50 m alt., Bejuco trepador; flores amarillo blanquecinas, 19 febr.-10 mar. 1944, *J. Cuatrecasas 16550 AMES(71363)! Cordillera Occidental; vertiente occidental: Hoya del río Anchicayá, lado derecho, bajando a La planta, bosques, 200-350 m alt.. Bejuco herbáceo, crasiúsculo; tépalos ocráceo blanquecinos; labelo amarillo claro. 27 sept. 1943, *J. Cuatrecasas 15220 AMES(71364,71365)! CHOCO: Parque Nacional de Utría: Colecciones realizadas en la serranía ubicada al este de la ensenada de Utría, en un recorrido oeste-este, entrando por la casa de la Señora Ana Elida (Mesica) siguiendo la trocha que conduce al acueducto cruzando por la quebrada Aguada. $6^{\circ} 20^{\prime} \mathrm{N}, 77^{\circ} 20^{\prime} \mathrm{W}, 0-100$ m. Epífita; flores amarillas, 30 Mayo $1990,{ }^{*} F$. García C. \& E.D. Agualimpia $325 \mathrm{MO}(3878341) ! \mathrm{CHOCO}$ (not seen). WITHOUT LOCALITY: No collection data: Climbing vine; sepals and petals pale yellowish-green; petals with flat ridge along center; lip white with crenulate, entire margins, inner throat with yellow and brown lines; column yellow; sweet, spicy fragrance. 6 May 1992, *S.W. Ingram 1421 SEL(066924)! same data *S.W. Ingram 1422 SEL(066925)!

5. Vanilla hartii Rolfe, Bull. Misc. Inform. Kew: 133. 1899.

TYPE: Trinidad, Cabasterre Arima, Hart 6355, holo. K!, iso. AMES(67785)!

V. leprieurii R. Port., Bull. Soc. Bot. France, 98: 94. 1951. 
Type: "Guyane Française: Cayenne, dans les forêts humides, Leprieur (s.n.), en 1846" (not seen, drawing!)

Common nAmes: "Vanilla", "vainilla".

Hemiepiphytic vine, branching, leafy, relatively weak, up to $3 \mathrm{~m}$ high; perhaps up to 8-10 $\mathrm{m}$ long. Stems terete and smooth, green, 3-6 mm thick; internodes 7.0$12.4 \mathrm{~cm}$ long. Aerial, free roots terete, pale brownish, 8-12 $\mathrm{mm}$ long, 1-2 mm thick; attaching roots up to $6 \mathrm{~cm}$ long, $2 \mathrm{~mm}$ wide, conspicuously flattened. Leaves usually slightly shorter than the internodes; conspicuously petiolate, the petiole straight or twisted, canaliculate, with a clear junction line with the blade, ca. 10-14 mm long, 1.5-3 mm broad (not flattened); blades elliptic, acuminate, rounded at base, coriaceous, green, 9-11 nerved (and a similar number of smaller veins intercalated); $6.0-11.5 \times 1.4-3.5 \mathrm{~cm}$. Inflorescence a short raceme with about 5-8 flowers, 13-30 mm long, 3-3 mm thick; peduncle of 4-7 internodes; rachis 5-15 $\mathrm{mm}$ long. Bracts sessile, variable, triangular-ovate, acuminate to obtuse (the upper ones), concave (the upper ones) to cymbiform, not very stiff, progressively smaller, 3.5-9 x 2.5-5 mm. Flowers successive, 1-2 open at a time, segments spreading, ephemeral, but at least some of them remaining for more than one day, relatively small, tepals white, the sepals tinged with green, lip white with grayish or brown faint lines on the throat and an inconspicuous green cushion at lip apex; ca. $3.8 \mathrm{~cm}$ high; fragrance imperceptible. Ovary terete, green, smooth, $2.7 \mathrm{~cm}$ long, $1.2 \mathrm{~mm}$ thick. Sepals fused at base ca. 2 $\mathrm{mm}$, subunguiculate and canaliculate at base, smooth. Dorsal sepal oblanceolate, apex acute, rounded, slightly thickened, flat to slightly concave, the apex slightly incurved, 12-veined, 39-49 × 6-8 mm. Lateral sepals obliquely oblanceolate, the lower margin more arcuate, apex obliquely subacute, rounded, thickened, slightly subcalyptrate, and obscurely warty, 12-veined, 39-46 x 7-8.6 mm. Petals obliquely oblanceolate, somewhat arcuate, the lower margin more straight, long attenuate at base, apex subacute to widely rounded, ca. 12-veined, smooth, slightly concave; with an axial, flattened keel on the abaxial surface, ending in a cylindric, acute, attached process, $39-50 \times 6-8 \mathrm{~mm}$. Lip attached to the column margins ca. 24-26 mm, long tubular, trumpet-shaped, basally gibbous, with an abaxial longitudinal groove; when spread out $37-43 \times 14-25 \mathrm{~mm}$; the claw slightly sigmoid, ca. $16 \mathrm{~mm}$ long, minutely papillose-pubescent; blade cymbiform, ca. $7 \mathrm{~mm}$ depth, subentire or entire, constricted near the apex and appearing slightly trilobed, the apex deflexed, obovate-flabellate, ca. 21-veined, basal half with inconspicuous rows of papillae up to the penicillate callus, distal part with thickened veins, inconspicuously papillose, the axial ones more prominent and forming an apical inconspicuous cushion, margins denticulate-undulate, plicate, apex truncate; penicillate callus at $26-30 \mathrm{~mm}$ from the lip base; ca. $4 \times 3 \mathrm{~mm}$, built up by ca. 7 flabellate-praemorse, retrorse, laceratelaciniate scales. Column very elongate and slender, semicylindric, 32-33 x 2-2.5 mm, apex dilated ca. 3-4 mm wide; slightly pubescent on the flat ventral surface, below the stigma, vertical wings flabelate-bilobed, with granulouse inclusions, ca. $3 \times 1.5 \mathrm{~mm}$, filament broad, thick, ca. $1 \mathrm{~mm}$ long, $2 \mathrm{~mm}$ wide. Anther versatile, obovoid, ca. $3 \times 2 \mathrm{~mm}$. Stigma trilobed, the lobes emergent; with a flabellate rostellum, with the lateral margins reflexed, the margin denticulate, ca. $3.5 \mathrm{~mm}$ broad; lateral lobes emergent, ovate-quadrate, tongueshaped, ca. 1 x $1 \mathrm{~mm}$. Fruit linear-fusiform, elongate, cylindric, not fleshy, slightly calyculated, dehiscent along 2 lines; fragrant, characteristic vanilla aroma, very sweet; 92-140 x 4-5 mm. Fig. 6, 16C.

Distribution: Mexico (Chiapas, perhaps reaching eastern Oaxaca), Belize, Guatemala, Honduras, Nicaragua, Costa Rica, Panama, Trinidad, Guyana, French Guiana, and probably Brazil.

Ecology: Rare in wet forests at low altitudes, usually growing on understory treelets, in deep shade. Flowering time January to April. The Mexican population of $V$. hartii is sympatric with $V$. cribbiana, $V$. insignis, $V$. odorata, $V$. planifolia, and $V$. inodora, but $V$. hartii is confined to the top of small hills with shorter forests and open understory with tree ferns and large sedges; the other vanillas are absent from this habitat although they may be found a few meters away. Female Euglossa bees have been observed visiting the flowers, but we do not know if they are effective pollinators. Vanilla hartii is a shy flower-producer; we have visited over many years the Mexican population during the flowering season, and we have found open flowers only twice, in the spring of 2000, and then in spring of 2002.

This species was first cited from Central America by Correll (1965). The Central American material of $V$. 


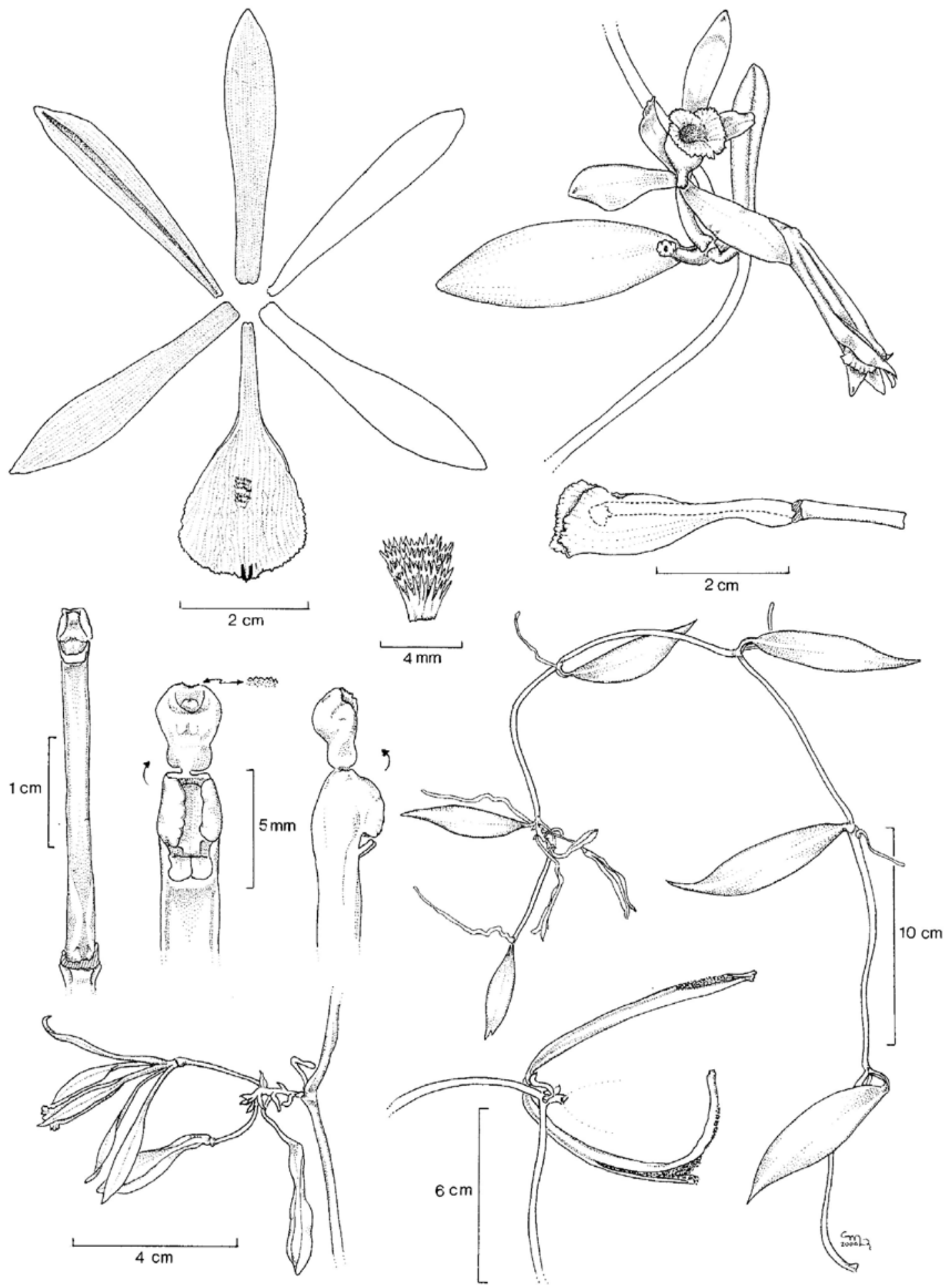

FiguRE 6. Vanilla hartii Rolfe, based on M. Soto 9729-9731. Drawing by M. López. 
hartii has slightly larger flowers (e.g., lip is 37-43 vs. $32 \mathrm{~mm}$ long) and the lip apex was described originally as acute to subobtuse, not obtuse to widely rounded. However, examination of flower of the type and pictures from Trinidad and Mexico show that they are indistinguishable, and that the floral differences may due to the herborization process. Three collections of $V$. hartii from the Pacific slope of Costa Rica are vegetatively stouter than Mexican and Trinidadian plants, and the flowers are also the largest examined. We do not know if these differences may indicate that they should be regarded as a distinct taxon; although molecular data suggest that they are closely related (see ITS analysis).

Vanilla leprieurii is here considered as a synonym of $V$. hartii. Portères (1954) stressed that his V. leprieurii was distinct because the nervation in the center of the lip was denser, with the zone before the nervation thicker, more imbricate scales in the penicillate callus, and the apex of the lip more emarginate, apiculate and pleated. Furthermore, the lip looks constricted, almost trilobed in the published drawing. All these features are variable in the material examined and again, they seem to be the result of the way in which the flowers were pressed.

Vanilla hartii is a relatively small vine similar to the $V$. planifolia group. It is somewhat similar to $V$. odorata but has shorter racemes, much smaller flowers, a gibbous lip base, subentire lip, denticulateundulate (not lacerate-fimbriate) lip margin, a cushionlike thickening at the lip apex without retrorse papillae (vs. the 3-4 longitudinal rows of apical, retrorse, big papillae) and broader and shorter elliptic leaves (vs. long triangular-ensiform). The elliptic leaves, shorter than the internodes, and the slender stems make it vegetatively similar to $V$. bicolor from the Caribbean and Guyanas. However, V. bicolor has acute to subacuminate lip, larger, tan-colored flowers with yellow lip, and stouter, more elongate inflorescence.

Most Nicaraguan and several of the Central American specimens previously assigned to $V$. planifolia are actually $V$. hartii. Also the reports of wild V. planifolia from Rio Palenque Center in Ecuador are based apparently in $V$. hartii (P. Lubinsky, com. pers.).

Vanilla hartii is morphologically similar to $V$. planifolia, and even confused with it in many treatments. However, all the molecular data place it in a rather basal position among the American penicillate vanillas. Vanilla hartii tolerates damper, more shady conditions, but the fragrant fruits are much smaller, and it is not a free-flowering plant.

OtHer RECORdS: MEXICO: CHIAPAS: Estación de Biología de Chajul, selva alta perennifolia, selva de loma con Calophyllum y sotobosque de cyperáceas altas y helechos arborescentes, sobre el camino a Arroyo Miranda, $16^{\circ} 07^{\prime} 35^{\prime} \mathrm{N}, 90^{\circ} 54^{\prime} 35^{\prime} \mathrm{W}$; 200 m s.n.m., 12-IV-1997, M. Soto $8347 * \mathrm{AMO}($ sterile)! $8350 * \mathrm{AMO}$ (fruit)! same data 14 abril 2000, M. Soto *9727(x2), *9729(x2), S. Maldonado, L. López y P. Schlütter AMO!; same data: flor blanca, tépalos algo más verdosos, especialmente en el engrosamiento apical, con líneas inconspicuas, cafés, tenues en la garganta, sin fragancia aparente. Rondada por Euglossa hembra, pero no capturada ni vista polinizando la flor. Fruto maduro con olor característico a vainilla, muy dulce M. Soto 9730, S. Maldonado, L. López y P. Schlütter *AMO! Sobre la Vereda La Granja, Estación de Biología de Chajul, selva alta perennifolia en zona de loma con muchos arroyos, algo perturbada, ca. $16^{\circ} 07^{\prime} \mathrm{N}, 90^{\circ} 54^{\prime} \mathrm{W}$, $200 \mathrm{~m}$ s.n.m. escasa, en floración, 15 de abril de 2000, M. Soto 9731 y P. Schlütter *AMO! BELIZE: TOLEDO: "Vianilla" Vine, flowers white, in broken Cohune Ridge, between Orange Point and Moho River, April 28 1952, P.H. Gentle 7673 MEXU(511492)! Southern Maya Mountains, Bladen Nature Reserve, mountain, 1.7 airline north of Ex Xux archeological site, $16^{\circ} 31^{\prime} 05^{\prime \prime} \mathrm{N}, 88^{\circ} 54^{\prime} 11^{\prime \prime} \mathrm{W}$, 500-600 m, vine, flower white, in tree fall gap, 24 May 1996, G. Davidse 36251 BM! COROZAL: [cf.] "vanilla", vine, P.H. Gentle $328 \mathrm{~F}(713628)$ ! GUATEMALA: IZABAL: Leaves subcoriaceous, dark dull green above, slightly paler dull green below. Stem terete, dull green. Petals and sepals pale greenish-white. Lip white. Leaves somewhat narrower than in typical $V$. fragrans. Swamps of Salomón Creek, 1/2-1 mi. south of Bananera, alt. $50 \mathrm{~m}$. April 6, 1940. J.A. Steyermark 38944 *F(1043051)! [cf.] Quebradas, 19-22, May 1919, H. Pittier 8589A NY(sterile)! *US(1013493; sterile)! HONDURAS: ATLANTIDA: [cf.], sterile Lancetilla Valley, near Tela, altitude 20 to $600 \mathrm{~m}$; "vainilla", creeping on tree in wet forest; frequent, Dec. 6, 1927-Mar. 20, 1928, P.C. Standley 52824 *AMES(36946, fruit)! F(582560)! *US(1407340; sterile)! NICARAGUA: ZELAYA: Monkey Point; ca. $11^{\circ} 35^{\prime} \mathrm{N}, 83^{\circ} 39^{\prime} \mathrm{W}$, elev 0-20 $\mathrm{m}$; beach and bluff near village; vine on understory tree, flower pale green, 7 Apr 1981, W.D. Stevens, B.A. Krukoff $20021 * \operatorname{SEL}(047700)$ ! [cf.] Ibo, drainage of Caño Sung Sung, $\mathrm{N}$ of road between Puerto Cabezas and Río Wawa; approximately $14^{\circ} 9-11^{\prime} \mathrm{N}, 83^{\circ} 29-31^{\prime} \mathrm{W}$, elev. less than 10 $\mathrm{m}$; gallery forest and adjacent savanna. Vine on tree trunk, sterile. W.D. Stevens \& B.A. Krukoff $10667 \mathrm{SEL}(036668)$ ! [cf.] Caño Zamora on Río Rama; ca. $11^{\circ} 57^{\prime} \mathrm{N}, 84^{\circ} 16^{\prime} \mathrm{W}$, 
elev. ca. $10 \mathrm{~m}$; gallery forest along caño, pasture land on plain. Epiphytic vine, sterile. W.D. Stevens, B.A. Krukoff $8835 *$ SEL(054718)! without data [the attached flower; leaf, comments and analytical drawing on envelope perhaps belong to $V$. planifolia] A.H. Heller s.n. *SEL(03849)! COSTA RICA: PUNTARENAS: Hilly slopes west of Villa Nueva and Río Naranjo. Evergreen rainforest formations on the seasonally dry Pacific slope. Elev. ca. $200 \mathrm{~m} ; 9^{\circ} 28^{\prime} \mathrm{N}$ $84^{\circ} 28^{\prime} \mathrm{W}$. Vine growing in partial shade $1 \mathrm{~m}$ up on stump. Greenish-white flowers. 10-12 Feb 1988, W. Burger, K. Swagel \& J. Gómez-Laurito 12251 F(2009056)! Cantón de Osa, Aguabuena. Cuenca superior de Quebrada Aguabuena. 842'40”N 83³1'40”'W, 200-400 m. Bejuco trepador colgante. Inflorescencia de brácteas verdes. Flor blanco verde, labelo blanco con mancha puntual, apical, verde, columna blanca, polinios amarillo blanco. 18 January 1991, G. Herrera 4846 INB! MO SAN JOSE: Río Savegre, aproximadamente $1 \mathrm{~km}$ antes de la entrada a la Finca La Gavilana, cerca de los límites del Parque Nacional Tapantí, selva lluviosa con Anacardium, ca. 200 n.s.n.m., trepadora, con cápsulas, relativamente muy robusta, E. Salas $1 \&$ M. Soto INB! HEREDIA: Sarapiquí, Chilamate. Finca El Bejuco, $\mathrm{S}$ end of Cerros Sardinal (N of Río Sarapiquí). $10^{\circ} 27^{\prime} \mathrm{N}, 84^{\circ} 04^{\prime} \mathrm{W}, 60 \mathrm{~m}$. Vine climbing in understory tree at edge of forest to 3-4 $\mathrm{m}$ (transplanted here from swampy area of primary forest nearby). Sepals and wing petals cream-white. Labellum pure white, gibbous at very base, constricted 1/4-1/3 towards apex, gibbous again (more prominently) in apical $3 / 4$, slightly narrowed before rotate margin. Labellum with grayish lines within. 24 January 1987. M. Grayanum 7998 \& T. Ray *MO(3593651)! PANAMA: PANAMA:cf.] Río Tecumen. Moist forest; herbaceous vine; scarce, January 3, 1924, P.C. Standley $29353 * \operatorname{AMES}(31441$; sterile)!

6. Vanilla helleri A.D.Hawkes, Phytologia 14(1): 34, 19-20. t. 13.1966.

TYPE: NICARAGUA: Dept. Chontales: 2 miles south of La Libertad on the road to Sto. Tomás, growing as a vine on a wild avocado (Persea sp.) tree, alt. 1900 feet, April 1962, A.H. Heller 7946, holo. AMES? (not located), iso., SEL(fragments and drawing)!

Hemiepiphytic vine, branching, leafy. Stems flexuous, terete to slightly subquadrate, sulcate, dark olive green, minutely and inconspicuously papilloserugose in living condition; 5-10 mm thick; internodes up to $15 \mathrm{~cm}$ long, the apical stems conspicuously covered with glaucous wax. Attaching, aerial roots flattened, 1-3 mm wide. Leaves subpetiolate, the petiole 9-12 $\mathrm{mm}$ long, the blade oblong-elliptic to oblanceolate (perhaps also elliptic), fleshy, abruptly constricted towards the acuminate apex (acumen 10-15 mm), 12$15 \times 2.5-4.5(-6) \mathrm{cm}$. Inflorescence a 12-20-flowered raceme, candelabrum-shaped, $4-10 \mathrm{~cm}$ long; peduncle 1-2 cm long. Bracts triangular-ovate, acute to obtuse, dark green, up to $9 \times 8 \mathrm{~mm}$. Flowers successive, 1 open at once, with partially spreading segments, ephemeral, showy, medium-size, sepals whitish, greenish at the apical half on the abaxial surface, petals whitish, lip bright yellow with orange appendages on the midlobe, column white; ca. $6 \mathrm{~cm}$ diameter. Ovary slender, subterete, white, apex green, 39-50 mm long, $3 \mathrm{~mm}$ thick. Dorsal sepal oblanceolate-elliptic, subacute-subobtuse, slightly concave, fleshy, slightly subcalyptrate at apex, 11-veined, 40-42 x 11-14 mm. Lateral sepals obliquely elliptic, obtuse, slightly concave, fleshy, subcalyptrate, 11-veined, 40-45 x 13-14 mm. Petals oblong-elliptic, oblique, subacute to obtuse, rounded, 11-13-veined, dorsally keeled, 40$47 \times 11-13 \mathrm{~mm}$. Lip attached to the column margins up to the stigmatic region, forming an inflated throat, cuneate, without a claw, the blade clearly trilobed, when spread out $35-40 \times 30-33 \mathrm{~mm}$; lateral lobes flabellate-obovate, rounded, margins entire to slightly repand with branched veins, ca. $5 \mathrm{~mm}$ wide at apex; midlobe subquadrate to transversely oblong, truncate, covered with retrorse, complanate, appendages up to $3 \mathrm{~mm}$ long, along the veins; disc with inconspicuous axial rows of minute warts, with abundant trichomes on the sides of the basal half; penicillate callus at 20-23 mm from the base, almost continuous with the axial warts and the apical appendages, a tuft of long laciniate, scales, much divided, ca. 5 x $5 \mathrm{~mm}$. Column subclavate, rather short and thick, semicylindric, 28 x $4 \mathrm{~mm}$, apex dilated ca. $5 \mathrm{~mm}$ wide; ventral surface with fine glandular hairs below the stigma; vertical wings subtriangular, subacute, filament broad, thick, ca. $1 \mathrm{~mm}$ long, $2 \mathrm{~mm}$ wide. Stigma trilobed, with a convex, flabellate midlobe, the margin entire, ca. 3.5 $\mathrm{mm}$ broad; lateral lobes emergent, quadrate, tongueshaped, ca. $1 \times 1 \mathrm{~mm}$. Anther versatile, transversely ellipsoid, ca. $3 \times 3$ mm. Fig. 7 .

Distribution: Costa Rica and Nicaragua, and also apparently in Oaxaca, Mexico. Our knowledge of the distribution of $V$. helleri is very fragmentary. It is known from the type locality on the slopes of the 


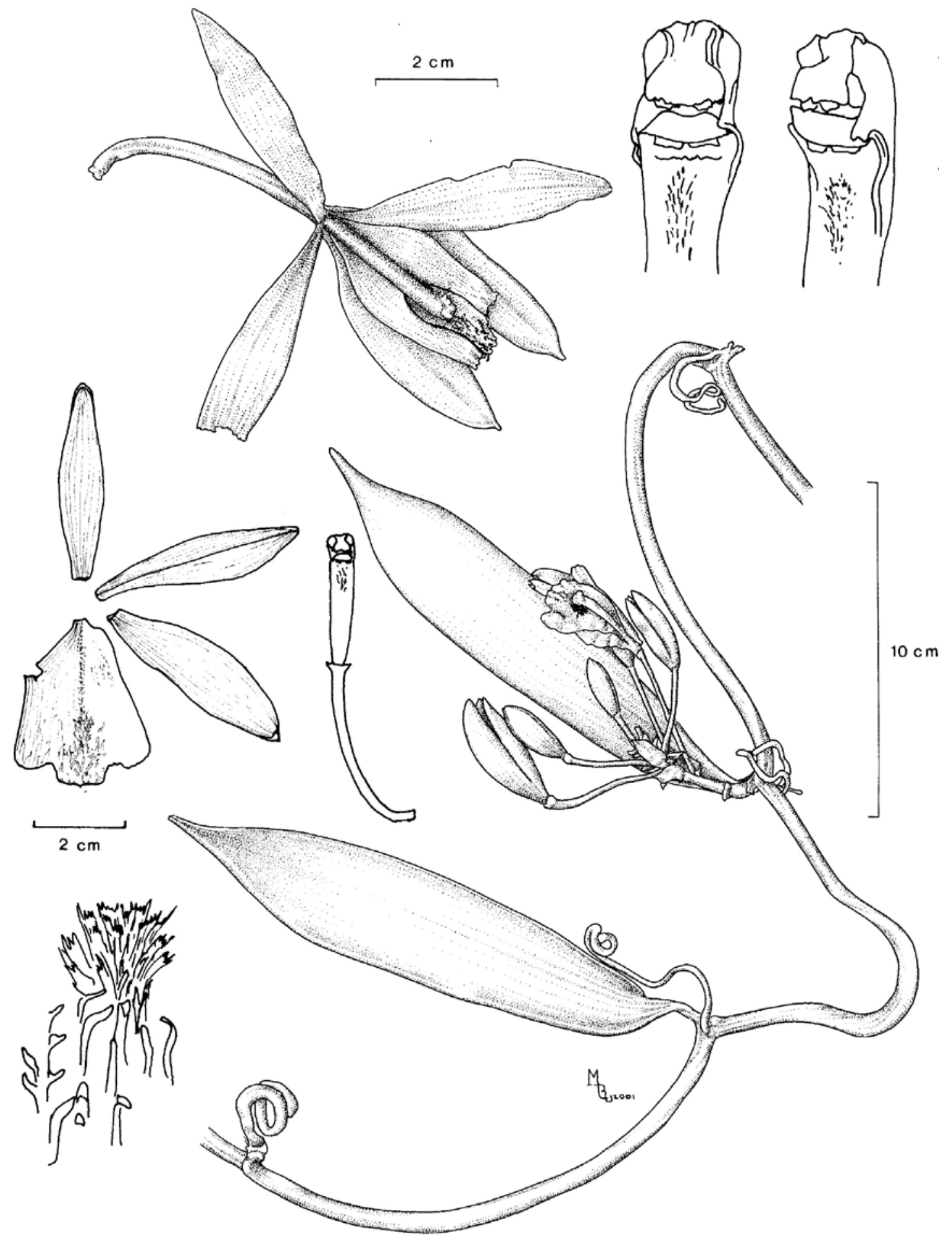

Figure 7. Vanilla helleri Hawkes. Based on G. Davidse \& R.W. Pohl 1503. Drawing by M. López and M. Soto. 
Cordillera Chontaleña, and on the Pacific slopes of $\mathrm{S}$ Costa Rica, especially in the Osa Peninsula.

ECOLOGY: In rainforest, with a short, marked dry season, at 200-570 m altitude; it flowers in MarchApril.

This species has a lip with elongate, complanate appendages, similar to that found in $V$. insignis. The outline of the lip, with a cuneate base lacking a claw is very anomalous among American penicillate vanillas and is reminiscent of some Old World species. In the original description Hawkes stressed that this species has no close allies in Central America. However, morphological and molecular data suggest that it is closely related to $V$. insignis and $V$. odorata, but the flowers are much smaller, and both these species have conspicuously long-clawed lip. Vanilla helleri, described 30 years ago is one of the rarest vanilla in the area; it is known only from a couple of flowering herbarium specimens. Despite its rarity in the herbaria, $V$. helleri could be more common than usually thought. Several specimens of it are growing at Finca La Gavilana, Río Savegre, Costa Rica. Additionally, several non-flowering plants, that may be this species, have been located around Sta. María Chimalapa, in Oaxaca, Mexico. Most Mexican specimens have rather elliptic, broader leaves than Costa Rican material, but they share the sulcate stems, papillose stem surface, abundant wax on stem apex, and the nucleotidic sequences are very similar to those of Costa Rica. Originally, the Mexican specimens were thought to be a hybrid between $V$. planifolia and $V$. insignis, since $V$. helleri has vegetative traits intermediate between these species. We hope to see their flowers some day.

OTHER RECORDS: COSTA RICA: PUNTARENAS: $2 \mathrm{~km}$ SW of the intersection of the Río Ceibo and Carretera Interamericana; elev. $200 \mathrm{~m}$. Large vine climbing in a tree. 18 March 1969, G. Davidse 1503 \& R.W. Pohl $\mathrm{F}(1731785)$ !

MEXICO: OAXACA: [cf.] Planta jóven, silvestre, en selva alta perennifolia con Sebastiania, Quercus oleides, Terminalia, Acacia, Ampelocera, ca. km 42 del camino Mezquite- Sta. María Chimalapa, 390 m s.n.m., 20 Marzo 1997, A. Cibrián 11 \& M. Soto (not preserved). [cf.] Tallos ásperos al tacto y subpapilosos, longitudinalmente sulcados; al sureste de Sta. María Chimalapa, vereda hacia el Río Milagro, paso Quetz Tug, 15/XI/98 a 6/XII/98, $H$. Hernández V7 sub M. Soto 8806 AMO(sterile, photo)! [cf.] Hojas subcuneadas en la base, algo oblanceoladas y algo oblicuas; $3 \mathrm{~km}$ al este de Sta. María Chimalapa, cerca de la cascada Arroyo Sangre. 15/XI/98 a 6/XII/98 H. Hernández V3 sub M. Soto 8811 AMO(sterile, photo)! [cf.] Tallos muy delgados, sulcados, ásperos, algo glaucos, hojas elípticas, flexibles y delgadas. Aproximadamente a $12 \mathrm{~km}$ al suroeste de Sta. María Chimalapa, a la orilla del camino Sta. MaríaEl Mezquite, en la bajada de Zacatal, 15/XI/98 a 6/XII/98, H. Hernández V8 sub M. Soto 8817 AMO(sterile, photo)! Tallos muy delgados, sulcados, ásperos, hojas elípticas, flexibles y delgadas. Aproximadamente $1 \mathrm{~km}$ al noreste de Sta María Chimalapa, a $5 \mathrm{~m}$ de la vereda de Paso Lagarto. H. Hernández V2 sub M. Soto 8818 AMO (sterile, photo, ITS sequence)!

References: Hamer, Orch. Nicaragua, Ic. Pl. Trop. pl. 1192. 1984; Hamer, Selbyana 11. Orch. Centr. A. p. 847. 1990.

7. Vanilla inodora Schiede, Linnaea 4(4): 574-575. 1829.

TYPE (?): "Baynilla de puerco Misantlensium"; Mexico, Misantla. Schiede 1044, K; "fruto inodori, Vanilla inodora nob. interin Vaynilla de puerco, Misantlensis .... Misantla, Mart 29 Schiede \& BM! W(s.n.; x2)!

Vanilla pfaviana Rchb.f., Gard. Chron. 2, 20. 230. 1883.

Holotype: "Mexico" actually from Chiriquí, Costa Rica, R. Pfau [269] W(19347)!

Vanilla preussii Krnzl., Notizbl. Bot. Gart. BerlinDahlem. 7: 320. 1919.

Type: Bei der Planzung El Baúl im Buschwald, Heisst bei den Eingeborenen "Vainilla silvestre" (Preuss n. 1445), not seen.

Common names: "Vainilla de puerco" (Ver.); "vainilla", "vainilla cerro amarillo" (Oaxaca).

Hemiepiphytic herb, vigorous, up to $12 \mathrm{~m}$ high. Stems terete, ca. 4-5 mm thick; internodes ca. 7.5 long. Leaves usually hanging and with bending blades; petiolate, the petiole ca. 1-2 cm long, twisted; blades elliptic to broadly elliptic, abruptely acuminate, thin, membranaceous when dry; $12-21 \times 4.5-7 \mathrm{~cm}$. Inflorescence similar to the vegetative shoots; ca. $30 \mathrm{~cm}$ long, bearing 3-5 flowers; the raceme bears progressively smaller foliaceous bracts. Bracts similar to the leaves, although smaller or much smaller, 3.3-12 x 1.0-5.2 cm; the internodes 3.5-7 $\mathrm{cm}$ long, ca. $2 \mathrm{~mm}$ thick. Flowers resupinate, with spreading segments, very showy, tepals apple-green or 

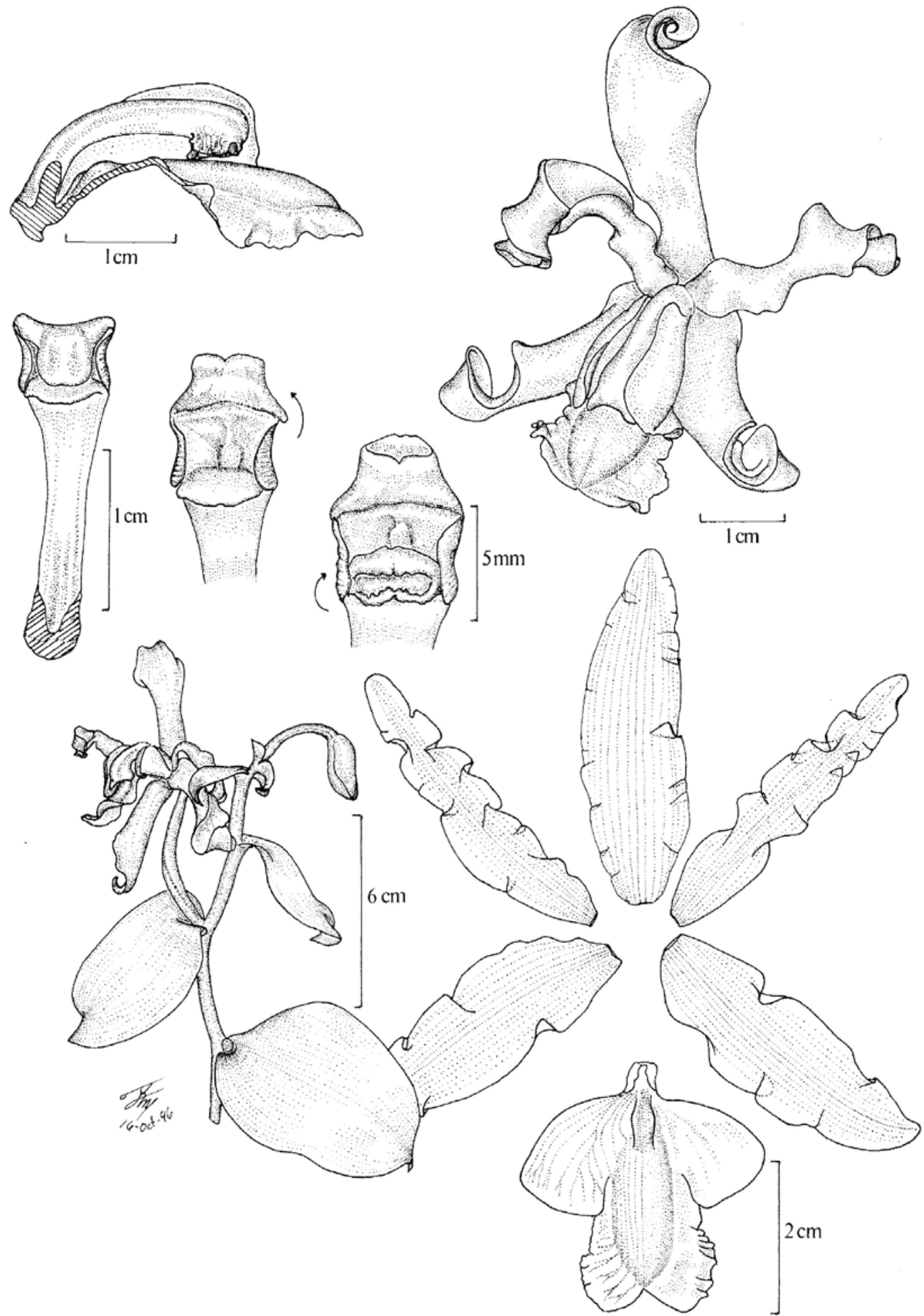

FiguRE 8. Vanilla inodora Schiede, based on M. Hernandez s.n. sub M. Soto 7864. Drawing by R. Jiménez. 
yellowish green, shiny, lip white with yellow-orange tinge in the throat; ca. $4.5-5 \mathrm{~cm}$ diameter; fragrance sweet strong or faint medicinal, to weak solanaceous alcaloids; flowers lasting 2-3 days. Ovary straight to slightly arcuate, terete, smooth, 3-sulcate, the grooves twisted, 47-55 (48.67 \pm 1.25$) \mathrm{mm}$ long, 3-4 (3.33 \pm 0.47$)$ $\mathrm{mm}$ thick. Tepals contorted, with very undulate, somewhat revolute margins, and the apices recurved or rolled backwards. Dorsal sepal erect, ellipticlanceolate, broadly obtuse to acute, ca. 11-veined, $44-50(47 \pm 2.19) \times 12-18(13.4 \pm 2.8) \mathrm{mm}$. Lateral sepals descending, elliptic-lanceolate, broadly obtuse to acute, ca. 11-veined, 41-44 (42.4 \pm 1.02$) \times 13-17$ (15_1.79) $\mathrm{mm}$. Petals spreading, elliptic-lanceolate, attenuate towards the obtuse apex, axially canaliculate

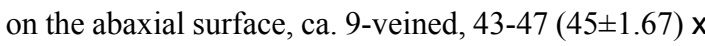
9-11 (10 \pm 1.26$) \mathrm{mm}$. Lip attached to the column ca. 2.5 $\mathrm{mm}$ at base; arcuate, trilobed, the lateral lobes covering the column, the midlobe spreading and deflexed; 27-36 (33 \pm 3.16$)$ mm long, 29-34 (31.6 \pm 1.62$) \mathrm{mm}$ wide when spread out; lateral lobes erect, semiobcordate, broadly rounded, reduplicated and covering the distal half of the column; $20-24.5(22.7 \pm 2.23) \times 9-13.5(12.2 \pm 1.69)$ $\mathrm{mm}$; midlobe subcuadrate, spreading, deeply

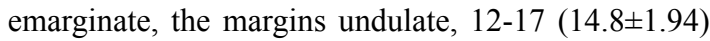
$x$ 13-19.5 (15.8 \pm 2.38$) \mathrm{mm}$; the midlobe and part of the disc with a massive, fleshy, elevated, cushion-like callus, 16-21 (18 \pm 1.79$) \mathrm{mm}$ long, 5-8 (6.8 \pm 1.16$) \mathrm{mm}$ broad, ca. 3-5 mm high. Column strongly arcuate, the apical part resting on the callus surface, 21-24 $(22.6 \pm 1.16) \mathrm{mm}$ long, 5-6.3 $(5.76 \pm 0.56) \mathrm{mm}$ wide at the apex. Stigma a well-defined, transversely oblongpanduriform cavity with thickened, yellow borders; without a rostellum. Anther hinge-like, broad, attached to the clinandrium, and forming together with it, a couple of lateral auricles. Pollen soft, somewhat sticky. Fruit cylindric with attenuate base and apex, not aromatic, $18 \mathrm{~cm}$ long, ca. $8 \mathrm{~mm}$ thick. Fig. 8 .

Distribution: Mexico (Puebla, Veracruz, Jalisco, Guerrero, Oaxaca, Chiapas), Belize, Guatemala, Nicaragua (Heller \& Hawkes, 1966), Costa Rica, and Panama.

ECOLOGY: Vanilla inodora grows in wet forests from 150 to $1600 \mathrm{~m}$ altitude; it is the only Vanilla that inhabits the cloud forests of the area, and is found in the lowlands only in sites with more than $2500 \mathrm{~mm}$ of rainfall. Flowering apparently without a defined period. It is sometimes found in savanas with slow drainage.

Vanilla growers believe that this species can be self-pollinated; the large fruit set in some populations supports this idea; however, other populations have a fruit set as low as $2.5 \%$. The flowers remain in good condition for 2-3 days, and are therefore long-lived compared with other vanillas; often older and younger flowers are at anthesis on the same raceme.

The flowers of this vanilla resemble those of some species of Schomburgkia group of Laelia in the flower structure; the tepals are contorted, strongly twisted, with a varnished appearance and the column lies on the lip surface; pollination must be carried out by large, strong bees that try to enter to the throat separating the lip from the column, as in Schomburgkia or Barkeria; in the latter this work is done by carpenter bees (Xylocopa), and they might be good candidates to pollinate this species. We have observed carpenter bees approaching $V$. inodora in Chiapas, but they were not been seen landing on the flower.

V. inodora was collected by Schiede near Misantla; the original collections are housed at $\mathrm{K}, \mathrm{BM}$ and W. None of the herbarium specimens bear flowers, although probably some specimens have had fruits (see Rolfe 1896); so its identity has been somewhat obscure. The type specimen is evidently a member of Portère's subsect. Membranacea, and as only a single species of this group is found in Mexico, and it is common in Veracruz, we discard the possibility of other species, from elsewhere, to which the name $V$. inodora has been applied. There is no evidence that the Mexican species is conspecific with the Haitian Vanilla mexicana, as suggested by many authors, despite the specific name of the latter. The large foliaceous bracts of $V$. inodora are larger than in other Membranaceous species and are clearly visible in the type.

Vanilla inodora has been known in recent years in the region as $V$. pfaviana Rchb.f. In their Orchids of Guatemala, Ames and Correll (1952) mentioned that they had not examined Guatemalan material of $V$. inodora and that the species could be conspecific with $V$. pfaviana. It seems, however, that the sterile specimens (or those very badly preserved) of this species were always identified as $V$. mexicana or $V$. inodora, while the material with flowers was thought to be $V$. pfaviana. Vanilla inodora and $V$. mexicana 
are similar, but the massive, elevated, fleshy callus of $V$. inodora is very different from the 3-keeled callus found in $V$. mexicana; furthermore, $V$. mexicana can have much larger leaves. It should be noticed that the callus of $V$. inodora may appear to be keeled in old, withering flowers or in young buds.

The type of $V$. preussii Kraenzl. was destroyed in the Berlin bombing, but the description matches $V$. inodora very well. Furthermore, Schlechter, who must have examined the type specimen identified Türckheim II 1764 as V. preussii.

The allied species in Central America are $V$. martinezii, from Guatemala, that is easily distinguished by the congested inflorescences, $V$. costaricensis with entire lip lacking a massive callus, and $V$. sarapiquensis, with short midlobe and a callus formed by two high, massive confluent ridges at the distal part of the lip. However, its closest relative may be the Andean V. methonica Rchb.f. \& Warsz., with a similar, emarginate lip, but having 3 thickened and somewhat rugose keels instead the fleshy massive callus, and much smaller inflorescence bracts.

OTHER RECORDS: MEXICO: JALISCO: Steep mountainsides 3-10 km generally east on the road to Mina Cuale, from the junction $5 \mathrm{~km}$ northwest of El Tuito, Mpio. Cabo Corrientes; pine-oak forest on decomposed granitic soils, with Podocarpus, oaks, and other deciduous trees in rocky stream valleys, elev. $850-1150 \mathrm{~m}$. Seen once, in rocky stream valley. Sterile; fleshy herbaceous vine climbing $10 \mathrm{~m}$ or more in trees, 16-19 February 1975, R. McVaugh 26397 MEXU! Mpio. Cabo Corrientes, $\mathrm{km} 2.6$ de la brecha hacia a la izquierda que sale del $\mathrm{km} 9.8$ del camino El TuitoCuale, bosque de galería de Hedyosmum, Inga, Podocarpus, Magnolia, Clusia, en medio del bosque sabanoide de pinos y encinos, sobre granitos intemperizados, $900 \mathrm{~m}$ s.n.m., $20^{\circ} 22^{\prime} 29.4$ " y $105^{\circ} 15^{\prime} 21.9$ ". Banco con suelo profundo con vegetación densa, similar a acahual de selva montana lluviosa con Heliconias, Philodendrum tripartitum, Lindenia y trepadoras. Hemiepífita, cerca $10 \mathrm{~m}$ de alto, con muchos frutos, cerca $400 \mathrm{~m}$ de extensión. Muy rara, sólo un espécimen visto. 27/junio/1998 M. Soto 8626 y E. Huerta *AMO(x6)! IBUG! GUERRERO: System of Teotepec, near San Vicente, N.E. of Atoyac, in mixed oak-pine forest on tree trunks. $100^{\circ} 16^{\prime} \mathrm{W}, 17^{\circ} 17^{\prime} \mathrm{N}, 850 \mathrm{~m}$, January 10 , 1933. O. Nagel sub E. Oestlund 1984 AMES (with sketch by B. Ames; 41396)! *AMES(51815)! *MO(11411617; sterile)!; San Vicente, north-east of Atoyac, towards Mt. Peineta. In mixed forest on trees \& shrubs, $100^{\circ} 16^{\prime} \mathrm{W}$, $17^{\circ} 17^{\prime} \mathrm{N}$, ca. $100-1000 \mathrm{~m}, 10$ Jan 1933. O. Nagel sub E. Oestlund 1985 *AMES(41476, sterile)! BM(sterile)!
*MO(1145095; sterile)! PUEBLA: Vicinity of Puebla, Venant des sierras (De la décoration florale à l'archevêché) Déc. 8. 1907. B.G. Arsène $1682 * \operatorname{AMES}(71359$, sterile)! *MO(843101, sterile)! NY! *US(1032010; fruit)! VERACRUZ: Miradores, 4/42 Liebmann 297 K! Mirador, Liebmann W(11762)! Hacienda de Java, 5/1841, Liebmann 295/296 W(13537, 13538, 11761)! Zacuapan, June 1919, C.A. Purpus 8481 *AMES(71356)! NY! Region of Zacuapan, near Rancho Viejo, climbing on tree trunks, ca. $700 \mathrm{~m}, 10 \mathrm{Jul}$ 1935, C.A. Purpus sub E. Oestlund 4876 *AMES(sterile, 51843)! *US(1809800)! Near Zacuapan. On trees and shrubs, $12 \mathrm{Feb} 1932,96^{\circ} 52^{\prime} \mathrm{W}, 19^{\circ} 12^{\prime} \mathrm{N}$, ca. $900 \mathrm{~m}$, O. Nagel sub E. Oestlund $2683 *$ AMES(sterile, 41475)! *US(1809491)! Region of Zacuapan, on tree trunks, 8 Oct 1935, ca. 800 m, C.A. Purpus sub Oestlund 5045 *AMES(fruit, 51838)! Falda del Volcán de San Martín Tuxtla, San Andrés Tuxtla, $18^{\circ} 35^{\prime}, 9^{\circ} 09^{\prime} \mathrm{W}$, alt. $800 \mathrm{~m}$ s.n.m., selva alta perennifolia primaria, suelo negro arenoso, buen drenaje, aluvial, cálido húmedo, lluvioso, escasa, flor blanca, 29-10-1973, J.I. Calzada 01031 BM! CHAPA! MEXU! El Mirador, Mpio. Totutla, bosque de encino en cañada, $1000 \mathrm{~m}$, herbácea trepadora, flor verde, centro blanco, fruto verde, escasa, 18-VI-1973, F. Ventura 8417 *AMO(436)! CHAPA! MEXU! Lote 67, Estación de Biología Tropical Los Tuxtlas, $95^{\circ} 04^{\prime}$ y $95^{\circ} 09^{\prime} \mathrm{O}, 18^{\circ} 34^{\prime}$ y $18^{\circ} 36^{\prime}$ N. Mpio. San Andrés Tuxtla, borde selva alta perennifolia, $300 \mathrm{~m}$ s.n.m, bejuco herbáceo, fruto verdegrisáceo, "vainilla", julio 14 de 1986, S. Sinaca C. 835 *AMO(7066)! OAXACA: Cerro Martín, cerca de Usila, $400 \mathrm{~m}$ selva alta perennifolia, predio de Sebastián Arista, 22 mayo 1993, M. Hernández s.n. AMO(in spirit)! Usila, M. Hernández s.n. AMO(in spirit)! Usila, 2 mayo 1994, M. Hernández s.n. AMO(in spirit)! Cerro Martín, ca. Usila, 1992, M. Hernández s.n. AMO(in spirit)! La Escalera, Chinantla. "Vainilla Cerro Amarillo". abril-1990. M. Hernández Apolinar sub M. Soto 10707 AMO! 1844, Mexico, Karwinski M W(19347, sketch)! Mpio. Sta. Ma. Chimalapa: Arroyo Sangre ca. $2 \mathrm{~km}$ E de Sta. Ma. Chimalapa, selva perturbada con Calophyllum, Tapirira, Brosimum, etc., suelo café parduzco con mucha hojarasca, $250 \mathrm{~m}, 16^{\circ} 54^{\prime} 30^{\prime \prime} 94^{\circ} 40^{\prime}, 20$ abril 1985, bejuco, flor blanca, sépalos verde, aromática, en cañada, común, usos se pone en aceite para el cabello, H. Hernández 1125 CHAPA! MEXU(564872)! Orquídea epífita, acahual derivado de selva alta perennifolia, loc.: Cuaje, Mpio. Ixtlán de Juárez, Dto. Ixtlán, Sierra Norte, 17/05/94, E. Torres 367 AMO(16696; young fruit)! TABASCO: Hierba epífita como bejuco, flor con 5 tépalos semienriscados y una quilla blanca, inflorescencia con brácteas foliares, asociada a pukté en vegetación riparia, Teapa, 31-05-1990, V. Ramón \& A Sol 309 MEXU [sterile]! CHIAPAS: "Local name: "vainilla", in wet forest, Libertad Acacoyagua, June 1 1948, E. Matuda 17912 AMES(66534; young fruit)! F(1616949)! 
MEXU(85052)! En Crucero Corozal, camino PalenqueBoca Lacantúm, Mpio. Ocosingo, 180 m s.n.m., bejuco con fruto, selva alta subperennifolia, 8 enero 1986, E. Martínez 15730 *LL! MEXU(436979)! MO(4272282)! *XAL! Triunfo, Dec. 1936, E. Matuda $360 *$ US(1689405)! TriunfoJuárez, Escuintla, Dic. 1936, E. Matuda 369 MEXU(85064)! Arroyo Miranda, entre los 6 y $20 \mathrm{~km}$ del arroyo partiendo del Río Chajul, Mpio. Ocosingo, 150 m s.n.m., primaria, orilla de arroyo, bejuco perenne, $8 \mathrm{~m}$, flor blanca, nom. vul. "vainilla", trepador, 20-02-1985, G. Castillo et al. 4011 *XAL! 2 km al NW de Lacanjá-Chansayab; Mpio. de Ocosingo, 400 m, enredaderas; vainas verdes, lisas, negras cuando maduras; numerosas semillas negras cubiertas con una secreción pegajosa de las paredes internas de las vainas; abundante en remanente de selva alta perennifoia relativamente madura, abril 16, 1991, M. González Espinosa et al. 1413 CHIP! MEXU(563979)! Bonampak, Mun. Ocosingo, $350 \mathrm{~m}$ s.n.m. selva alta perennifolia, suelo arcilloso. "Vainilla de montaña". Enredadera muy escasa, hasta de $7 \mathrm{~m}$ de largo. abril 1982. M. Soto 1020 AMO! Estación de Biología Chajul, Mpio. Ocosingo, ca. $200 \mathrm{~m}$ s.n.m., $16^{\circ} 08^{\prime} \mathrm{N}, 90^{\circ} 53^{\prime}$ O. Cerca del Puente Hamaca en la vereda a la Sabana I. Loma con selva mediana-alta perennifolia, en la base de la loma. Muy escasa. 23 junio 1996. M. Soto 7954-A y R. Solano *AMO! km 223.6 de la carretera Palenque-Marquéz de Comillas, ca. de Benemérito de las Américas, selva mediana subperennifolia con Cocoloba y Roupala, 220 m s.n.m., 11-IV-1997, M. Soto 8342 et al. AMO(also in spirit)! Mpio de Ocosingo, ca. de las ruinas Los Sótanos-El Zapote, Estación de Biología de Chajul, selva alta perennifolia inundable con Bactris, 230 m, $16^{\circ} 08^{\prime}$ N, $90^{\circ} 53^{\prime}$ O. Sobre Guarea en sombra densa, con frutos. 12-IV-1997. M. Soto 8343 *AMO! Estación de Biología de Chajul, junto al Río Lacantun, vereda La Granja, en la intersección con la vereda a La Sabana, selva alta perennifolia con Ficus glabrata en suelos profundos, arenosos, probablemente inundables estacionalmente, flor verde con labelo blanco, fragancia dulce, intensa, 15 de abril de 2000, M. Soto 9726 \& P. Schlütter *AMO! BELIZE: TOLEDO. Gracie Rock, Sibun River, 1 May 1935, P.H. Gentle 1672 *AMES(42338)! *LL! "Vainilla". Climbing plant, on cohune tree, white flowers, in cohune ridge, near river beyond Columbia. January 31, 1947, P.H. Gentle 6152*F(1599314)! G! *LL(x3)! NY! *US(2572753)! "Vainilla". Climbing vine, white flowers, in acahual, near Ocotal, Pine Ridge, 3 miles in trail from 7 Miles, Punta Gorda-San Antonio Road, January 20, 1950, P. Gentle 6957 *LL(x3)! MEXU(511462)! *MO(3832518)! "Vianilla", vine, in acahual, Feeders Road leading to Big Fall, April 13, 1950, P.H. Gentle 7023 *LL(fruit, x2)! "Vianilla", vine, in cohune ridge, one mile from 7 Miles, San Antonio-Punta Gorda Road, July 1, 1950, P.H. Gentle 7078 *LL(sterile inflorescence, $x$ 2)! "Vianilla", vine, in cohune ridge, near
Columbia, August 15, 1950, P.H. Gentle $7108 *$ LL(fruit)! GUATEMALA: IZABAL: [cf., sterile] wet forest,. "Vainilla". Creeping on tree trunk. Near Entre Ríos, alt. about 18 m., April 30, 1939, P.C. Standley 72709 F(991636)! ESCUINTLA: [cf., sterile] El Zapote, in jungle, on tree of Ficus, April 9, 1937, W.C. Muescher 12480 F(905455)! SAN MARCOS: [sterile] "vainilla", climbing, leaves fleshy coriaceous, rich green above, practically same color but slightly paler beneath, above Finca El Porvenir on "Todos Santos Chiquitos", lower south facing slopes of Volcán Tajumulco, alt. 1300-1500 m, March 7, 1940, J.A. Steyermark 37076 F( 1041850)! HUEHUETENANGO: [cf.] Epiphyte, alt., At 3000 ft. alt. Cerro Chiblac, between San Rafael and Ixcán, Sierra de los Cuchumatanes, July 22, 1942, J.A. Steyermark 49171 *AMES(63277, sterile)! F(1495682)! SUCHITEPEQUEZ: [cf., sterile] Epiphyte on tree on bark, leaves fleshy subcoriaceous, dull dark green above, dull green beneath, stem pale green, in cafetal on opposite side of Finca, southern lower slopes of Volcán Zunil, vicinity of Finca Las Nubes, along Quebrada Chita, east of Puebo Nuevo, alt. 500-800 m, Feb 2, 1940, J.A. Steyermark 35412 F(1041244)! BAJA VERAPAZ: Wald in Paujal, 1000 met April 1907, Bl. grün, Lippe weiss, H. von Türckheim II 1764 *US(825825)! HONDURAS: COLON: [cf.] Vine, flower white, Guaranta, Wispernini Camp, 75$100 \mathrm{ft}$., tropical rain forest, March 1938, C. von Hagen \& $W$. von Hagen 1352 F(942976)! NY! ATLANTIDA: [cf.] banks of the Salado River, above the village of Salado ... on the mountain slopes and coastal plains, vicinity of La Ceiba, July 10, 1938, T.G. Yuncker 8335 *AMES(fruit, 50661)! NY! COSTA RICA: ALAJUELA: Reserva Biológica Monteverde. Río Aguas Gatas, Laguna de Arenal, El Castillo. $10^{\circ} 26^{\prime} \mathrm{N} 84^{\circ} 44^{\prime} \mathrm{W}, 600-1000 \mathrm{~m}$. Epífita semi-liana dentro del bosque. Flor con caliz verde, corola blanca en forma de tubo. 11 August 1989, E. Bello 1146 INB! [cf., without flowers] Reserva Forestal de San Ramón; camino entre el Río San Lorenzo y la estación. $10^{\circ} 12^{\prime} 53^{\prime} \mathrm{N}$, $84^{\circ} 36^{\prime} 28^{\prime}$ 'W. Epífita trepadora, frutos inmaduros verdes. $G$. Herrera Ch., I. Chacón, D. Hernández, A. Solis y H. Gómez 386 SEL(062313)! CARTAGO: vainilla, "Chitería" = Chitaría, alt. $750 \mathrm{~m}, 15 / 4 / 36$, F. Solís F(833816)! [cf., sterile] LIMON: Epiphyte, $7 \mathrm{~km}$ al SW de Bribrís, 100-250 m, May 41983 [sterile], L.D. Gómez, R. Liesner, E. Judziewicz 20437 MEXU! MO [cf., sterile] San Clemente, Apr. 1920. Lankester (k331) K! SAN JOSE: Herbaceous vine, attached by roots. Fls green with white labellum, in forest. Vicinity of El General, alt. 1130 m, Feb. 1936, A. Skutch 2592 AMES(*44231, *44232, *44233)! K! *MO(1105371)! NY! [ Cataratas de San Ramón, marzo de 1931, A.M. Brenes 13679 F(906350)! PUNTARENAS: Cantón de Osa. Fila costeña. Río Piedras Blancas, cerca de la casa. Cerro Anguciana. Fila Cruces, $08^{\circ} 49^{\prime} 02^{\prime \prime} \mathrm{N}$, $83^{\circ} 11^{\prime 2} 23^{\prime \prime} \mathrm{W}, 900 \mathrm{~m}$. Bejuco trepador. Caliz verde, labelo 
blanco. 10 December 1993. R. Aguilar 2736 INB! PANAMA: BOCAS DEL TORO: [cf.] Vanilla, epiphyte; flower pale green, Big Bight, Vicinity of Chiriquí Lagoon, Oct., 27, 1940, H. von Wedel $2880 * \operatorname{AMES}(61513$, sterile)! REFERENCES: Ames, Bot. Mus. Leafl. Harvard Univ. 4(3): 26-29. fig. p. 29. 1936.

8. Vanilla insignis Ames, Bot. Mus. Leafl. 2(8): 101102. fig. p. 103. 1934.

TYPE: REPUBLIC OF HONDURAS, Dpt. Comayagua, Esquías, El Río Funes. Epiphyte in river-valley forest at 2,500 feet altitude.Sepals and petals green, lip white at base. April 27, 1933.J.B. Edwards 407, holo. AMES(40085)!; isotype AMES(40086)!

Common names: "Sisbic" (Maya), "vainilla", "vainilla cimarrona" (Veracruz).

Hemiepiphytic, branching, leafy vine, usually very vigorous, up to $30 \mathrm{~m} \mathrm{high}$; up to a hundred meters long. Stems flexuouse, subterete, with a conspicuous groove along the entire internode, surface fairly rugose-papillose, dark to olive green, ca. 6-9 mm thick; internodes, $10-17 \mathrm{~cm}$ long. Terrestrial roots pubescent, brown-whitish, ca. 2-3 mm thick; aerial free roots, terete, greenish gray, ca. $1 \mathrm{~mm}$ thick; aerial attaching roots semicylindric, flattened in the surface in contact with the substrate, ca. 3-4 mm wide. Leaves subpetiolate, petiole canaliculate, up to $11 \mathrm{~mm}$ long, $4 \mathrm{~mm}$ wide;blade oblong-elliptic, abruptly acuminate at the apex, rounded at base, coriaceous-fleshy, rather stiff, $4.2-19.5 \times 1.5-3.4 \mathrm{~cm}$. Inflorescence a 6-12(21)-flowered raceme, candelabrum-shaped, 4.4-11 cm long; peduncle fleshy, subterete, slightly compressed, 15-25 mm long, 6.5-8 mm thick; rachis $28-90 \mathrm{~mm}$ long, progressively slender towards the apex. Bracts sessile, small, broadly ovate, obtuse, concave, fleshy, progressively smaller towards the apex, commonly less than $9 \times 6 \mathrm{~mm}$, rarely up to $10 \times 10$ $\mathrm{mm}$. Flowers successive, 1-3 open at once, ephemeral (from 8:00 to 14:00 hrs; starting to close at noon), very showy, segments completely spreading, tepals pale apple-green, shiny, lip cream-white with orange to dull yellow appendages on the midlobe, extreme apex green, penicillate callus cream, column white; ca. 11-12.4 cm wide, 9-11 cm high; fragrance weak, spicy. Ovary subterete, very slightly dorsiventrally compressed, smooth, arcuate, 2-sulcate, the grooves almost straight, $45-54(48.75 \pm 3.27) \mathrm{mm}$ long, 4.5-5.5 $(5 \pm 0.41) \mathrm{mm}$ thick. Dorsal sepal long oblanceolate, apex acute, disatally rounded, slightly thickened, subcalyptrate, base attenuate-subunguiculate, claw ca. $22 \times 11 \mathrm{~mm}$, basally canaliculate, concave at middle, fairly incurved at apex, ca. 12-13-veined; 69-76.5

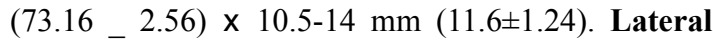
sepals obliquely oblanceolate, the lower margin more arcuate, apex subacute, thickened, apiculate, subcalyptrate, smooth, the abaxial surface minutely warty, especially at the minute apicule, base attenuatesubunguiculate, basally canaliculate; slightly concave towards the apex, margins somewhat involute, ca.

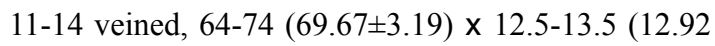
$\pm 0.35) \mathrm{mm}$. Petals obliquely linear to oblanceolate, somewhat arcuate, apex obtuse, distally rounded, oblique, subcalyptrate, base long attenuate; concave, with a very conspicuous, axial, elevated, flat keel at the abaxial surface, ending in a subtrigonous, free, adpressed process, ca. $2 \mathrm{~mm}$ long; ca. 12-14-veined, 68-74 $(70.9 \pm 2.11) \times 9-10(9.76 \pm 0.39) \quad \mathrm{mm}$. Lip fused to the column along the margins of the basal half $(37-44 \mathrm{~mm})$, long tubular, slightly concave, fairly inflated near the base of the blade; the apex conspicuously recurved-deflexed; axially grooved on the abaxial surface, the groove deep; when spread out $65-73(69.33 \pm 2.49) \times 30-35(32.6 \pm 1.62) \mathrm{mm}$; long unguiculate, adaxial surface of claw hairy on the distal half, the trichomes dense, more or less in rows; ca. 26 x $7 \mathrm{~mm}$; the blade approximately obovate-flabellate in outline, trilobed, ca. 30-veined, the veins branched above the middle, thickened forming low, obscure, flat keels near the base, disappearing near the basal third of the blade; lateral lobes subelliptic, oblique, ca. 33 x $10 \mathrm{~mm}$, margins long laciniate-fimbriate, especially near the joint with the midlobe; cilia up to $7 \mathrm{~mm}$ long; midlobe ovate-suborbicular to oblong, obtuse, the margin undulate-crenulate to lacerate-dentate towards the lateral lobes, $11-15(13 \pm 1.41) \times 12.5-14(13.37$ $\pm 0.65) \mathrm{mm}$; penicillate callus at ca. $34 \mathrm{~mm}$ from the base, $4 \times 5 \mathrm{~mm}$; made up by ca. 13 imbricated, retrorse, flabellate, praemorse to densely laceratelaciniate scales, sometimes united to each other along the lateral margins, scales almost without adpressed processes on the surface, continuous towards the lip apex with 7 rows of tubercles, near of the base of the 

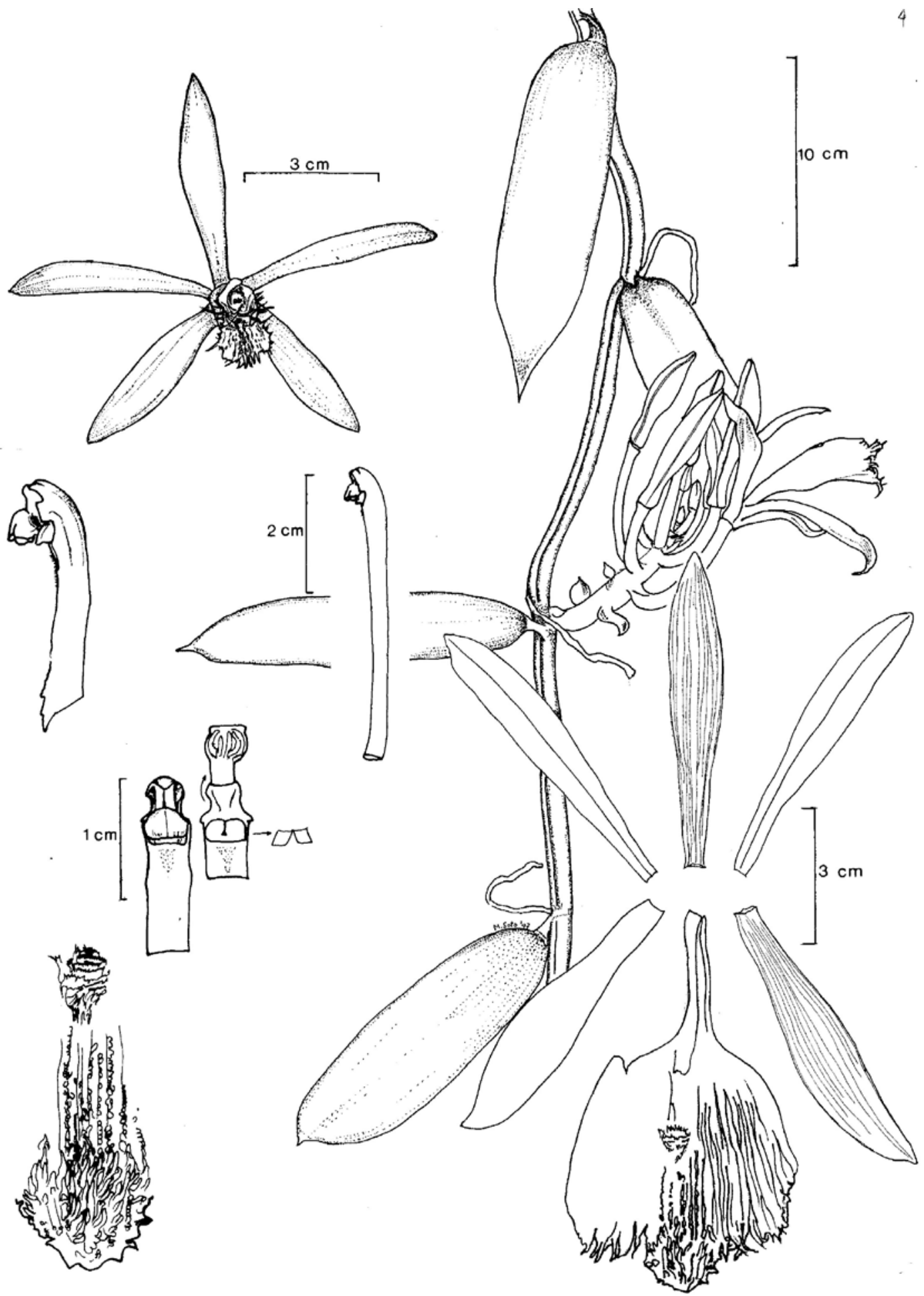

FiguRE 9. Vanilla insignis Ames. Based on M. Soto 7684. Drawing by M. Soto. 
midlobe becoming enlarged to form conspicuous, retrorse, subtriangular, thick, complanate, sometimes conical, obtuse appendages, that cover almost entirely the surface of the midlobe, distributed approximately in 10 rows, the central appendages bigger, up to $4 \mathrm{~mm}$ long, $1 \mathrm{~mm}$ wide; extreme apex thickened, mound-shaped. Column very elongate and slender, semicylindric-trigonous, $49-52 \quad(50.37 \pm 1.08) \quad \mathrm{mm}$ long, $4 \mathrm{~mm}$ wide; ventral surface flat, with scarce, minute trichomes below stigma; apex dilated, with vertical flabellate, somewhat trilobed wings, ca. 1.5 x $2.3 \mathrm{~mm}$; clinandrium galeate, ovate, convex, $2 \times 2$ $\mathrm{mm}$. Stigma trilobed, the lobes emergent, midlobe (rostellum) a transversely oblong, convex blade, axially grooved, ca. $3 \times 4 \mathrm{~mm}$, covering and parallel to the lateral lobes, these quadrate, rounded, convex, slightly divergent from each other, ca. $1.5 \times 1.5 \mathrm{~mm}$. Anther versatile, saddle-shaped, axially canaliculate, $3 \mathrm{~mm}$ wide, $1.8 \mathrm{~mm}$ thick, attached to the clinandrium margin by a thick, approximately semiterete filament. Pollen in monads, not forming a clear pollinarium but an ill-defined, sticky mass. Fruit short, thick, subclaviform-semifusiform, rounded, swollen towards the apex, green turning yellow when ripe, dehiscent along a single line, fragrant (less than $V$. planifolia), like a blend of common vanilla with coconut; ca. 7-14 $\mathrm{cm}$ long, $0.7-1.75 \mathrm{~cm}$ thick $(\mathrm{n}=6)$. Fig. 9, 17C.

Distribution: The Caribbean watershed of N Central America, in Honduras, Belize, Guatemala, and Mexico (Yucatán, Quintana Roo, Campeche, Chiapas, Tabasco, Oaxaca, and Veracruz; perhaps also in Puebla). Reported from Panama (Dressler, 1993) but the report seems to be based on specimens of $V$. dressleri.

Ecology: From the level to ca. $900 \mathrm{~m}$ elevation. Vanilla insignis is probably the most common vanilla in Mexico (Soto Arenas, 2003), where it is widely distributed and forms large populations. It grows in dry and wet areas (1000 to $4000 \mathrm{~mm}$ of annual rainfall), but in the latter, is confined to savannas with especial edaphic conditions. It has been recorded only from calcareous substrates. In the Yucatan Peninsula it grows in the subdeciduous forests of Bucida buceras, Brosimum alicastrum, and Manilkara sapota, often with the understory dominated by the palm Cryosophila argentea; these areas have slow drainage during the rainy season, and are frequently associated to the flooded areas ("tintales") with Haematoxylon
campechianum.In the much moister areas of Chiapas, it is found in savannas with Coccoloba belizensis, Quercus oleoides, and Roupala borealis.In Central Veracruz $V$. insignis grows in tropical deciduous forest or in warm oak forest.

Some specimens in Campeche and Chiapas seem to occupy areas up to $4,000 \mathrm{~m}^{2}$, and undoubtedly they are the largest plants of any Vanilla of the area. Some of these specimens may prove to be the most massive orchidaceous specimens in the world, with weights of many tons. It flowers in April and May; fruits become ripe in March-April. The flowers are visited by male bees of Eulaema polychroma.

This is another member of the $V$. planifolia complex and it has been considered conspecific with $V$. planifolia by some authors (e.g. Williams, 1956). However, it is clearly a distinct species; the flowers, though larger, are rather similar to those of $V$. planifolia in pressed specimens. The floral fragrance is also similar to that of V. planifolia (1-2-dimethil-ciclopentane, ethyl acetate, and 1-8-cineol as principal constituents, although ocimene-trans is notoriously absent.

It is easily recognized because the stems have internodes conspicuously sulcate and their surface is fairly rugose-papillose. Similar vegetative traits are found in some very distantly related Asian species, namely $V$. yersiniana Guillaumin \& de Sigaldi, $V$. moonii Thwaites, and it allies. The sulcate stems are thought to be an adaptation that permits the stem to store more water during the rainy period in seasonal areas, since the groove expands and becomes inconspicuous when the stem tissues are swollen. The characteristic flowers are large, ca. 11-12 cm in diameter, with green tepals, cream-white lip, the midlobe adorned with thick, triangular, retrorse projections, up to $4 \mathrm{~mm}$ high. The fruit (ca. 10-12 cm long) is thick and fragrant when ripe, but the aroma is similar to a mixture of vanilla with coconut.

The ITS tree (Fig. 1) and a survey of additional genomic regions, including also non-Mesoamerican Vanilla species show that the closest relatives of $V$. insignis are $V$. odorata Presl, V. helleri A.D.Hawkes, $V$. uncinata Huber ex Hoehne, and $V$. tahitensis J.W.Moore. Vanilla odorata, $V$. uncinata, and $V$. tahitensis have much narrower leaves, non-sulcate stems, smaller flowers, and less developed retrorse appendages on the lip. From $V$. helleri, from Oaxaca, 
Nicaragua and Costa Rica, with which it shares the papillose stem surface, sulcate internodes, and long, retrorse, orange-coloured papillae on the distal part of the lip, it can be easily distinguished by the long claw of the lip found in $V$. insignis vs. the cuneate lip blade of $V$. helleri.

Vanilla insignis was described in 1934, and it is surprising that it has not been reported until recently from Mexico (Carnevali et al., 2001; Soto Arenas, 2003) although it was collected in Veracruz by C.A. Purpus in 1919. Neither has it been reported so far from Guatemala or Belize, although a picture of $V$. insignis appeared wrongly identified as V. pfaviana in "Native Orchids of Belize" (McLeish et al., 1995). However, this species has been known and used by the Mayas for a long time, who call it "sisbic". Almost all the specimens previously identified as $V$. planifolia or $V$. fragrans from the Yucatan Peninsula and Veracruz belong to $V$. insignis. The report of $V$. odorata from Quintana Roo, based on Cabrera 4611 (Soto Arenas, 1989) is based in a specimen with buds that is actually $V$. insignis.

Vanilla insignis, could add desirable features to the commercial vanillas; it also has fragrant fruits, it is a more xerophytic, stouter species, and apparently tolerates clayey soils, seasonally flooded in summer. We have cultivated this species and it is also the Mesoamerican species most tolerant to low and high temperatures, and much more resistant to the attack of pathogens than $V$. planifolia.

Other RECORDS: MEXICO: VERACRUZ: Zacuapan, June 1919, C.A. Purpus 8482 *AMES(71362)! NY! Near Zacuapan, in humid forest on shrubs and on trees, $13 \mathrm{Feb}$ 1932, 96 $52^{\prime}$ ' W, $19^{\circ} 12^{\prime} \mathrm{N}$, ca. $900 \mathrm{~m}$, O. Nagel sub E. Oestlund 2682 AMES(*41478, *51844, sterile)! Region below Zacuapan, on shrubs, humid forest, 8 Jul 1936, ca. $800 \mathrm{~m}$, C.A. Purpus sub E. Oestlund 5961*AMES(51845)! Near Zacuapan, in humid forest on shrubs, 15 Jun 1935, ca. 800 m, C.A. Purpus 4866 AMES(*51849 fls. in spirit not seen, *51848, sterile)! Carretera Xalapa-Veracruz, km 16 SE of Xalapa, $1 \mathrm{~km}$ SE of main Jalapa-Huatusco highway, $5 \mathrm{~km}$ SW of bridge over Río Los Pescados, $5 \mathrm{~km}$ (by air) SE of Tuzamapan, Mpio. Coatepec, $19^{\circ} 21^{\prime} \mathrm{N}, 96^{\circ} 50^{\prime} \mathrm{W}$, $680 \mathrm{~m}$ alt., "selva baja caducifolia", thorn scrub along now dry canyon, now very dry and most trees without leaves. Vine to $3 \mathrm{~m}$, fruits green, hanging, March 19, 1983, M. Nee \& K. Taylor $26045 \mathrm{~F}(1985066)$ ! *XAL! Mpio. Emiliano Zapata, Cerro de Chavarrillo, $19^{\circ} 26^{\prime} \mathrm{N}, 96^{\circ} 47^{\prime} \mathrm{W}$, alt. 850 m s.n.m., selva baja, primaria, suelo arcilloso, pedregoso, color negro, muy seco, cálido, bejuco perenne, $6 \mathrm{~m}$, escaso, fruto verde; trepadora, 15-04-1979, G. Castillo \& L. Tapia 531 F(1963631)! NY! *XAL! Mpio. Emiliano Zapata, desviación de la carretera Xalapa-Veracruz, $16 \mathrm{~km}$ al SE de Xalapa, a $900 \mathrm{~m}$ de la carretera, enredadera, flor blanca y amarillo, escasa, "vainilla", 23/V/1976, C.H. Ramos 402 MEXU! [cf., fruits] Mpio. Soteapan, San Fernando, 18 17', $600 \mathrm{~m}$, acahual, selva alta perennifolia, 2-3 m, "vainilla", 19-IX-86, (usos) aromatizante de aceite, M.C. González R. $303 *$ XAL! OAXACA: [cf., sterile] Forests ca. $25 \mathrm{~km}$ east of Mogoñé, near Río del Corte. On shrubs, rooting with long aerial roots in leafmould. Isthmus of Tehuantepec, ca. $94^{\circ} 57^{\prime} \mathrm{W}, 17^{\circ} 0^{\prime} \mathrm{N}$, alt. ca. $100 \mathrm{~m}, 20$ feb 1935, O. Nagel sub E. Oestlund 4584 AMES(51847)! *US(1805098)! Plan Juan Martínez, camino Reforma-Ayozintepec, $80 \mathrm{~m}$. Comprada al Sr. Eugenio Hilario Justo, quien la colectó expresamente para nosotros. 19-III-1997, M. Soto 8120 y A. Cibrián *AMO(sterile)! TABASCO: [cf., sterile] Balancán, carretera no. 25, km 45 del entronque con la carretera E.W.O. hacia la carretera W-10, 10 m s.n.m. selva mediana subperennifolia primaria, asoc. Manilkara sapota, cálido húmedo, epífita, perenne, $5 \mathrm{~m}$, escasa, nom. vul. "vainilla", 06-12-1975, P.E. Valdivia 2063 XAL! CHIAPAS: [cf., fruits] La Cueva, al NW del Rancho Corocito, Reserva del Ocote, Mpio. Ocozocuautla. Alt. 770 m s.n.m., selva mediana perennifolia, primaria, suelo negro delgado con rocas calizas, ruderal, hierba, perenne, $3 \mathrm{~m}$, escasa, fruto verde, nom. vul. vainilla, 29-04-1983, J.I. Calzada, P. Gómez \& B. Gómez 9695 *XAL! Mpio. Ocosingo, Estación de Biología de Chajul, Sabana I, a unos $3 \mathrm{~km}$ del Río Lacantúm, bosque sabanoide con Roupala, Byrsonima, Scleria, Pteridium, ca. $200 \mathrm{~m}$ s.n.m. 1608' N, 9053' O. 13-IV-1997, M. Soto 8361 *AMO(buds)! CAMPECHE: Tuxpeña, Dec. 1, 1931, C.L. Lundell 1070 F(700398)! Selvas medianas subperennifolias (ManilkaraChryosophila) y bajos inundables, entre el Ejido 20 de Noviembre y las ruinas de Río Bec, Reserva de Calakmul, Campeche. Abundante, plantas más pequeñas que en Nueva Vida, sólo una vista con botones. Los mayas del ejido no la conocen. 11-IV-1995. M. Soto, E. Martínez, G. Tavera, et al. 7656 *AMO! Reserva de Calakmul, cerca de Zoh Laguna, selva mediana subperennifolia con Cryosophila argentea, ca. $200 \mathrm{~m}$ altitud, 14 abril 1995, tépalos verdes, labelo crema con apéndices anaranjados, frutos aromáticos, fragancia a vainilla y coco, $M$. Soto $7667 \mathrm{AMO}(\mathrm{x} 2$, also in spirit)! same data, [fruits], M. Soto $7670 *$ AMO! Reserva de Calakmul, ca. de Nuevo Becar, en bajo, 13-IV-1995. $M$. Soto 7681 *AMO! Ejido Nueva Vida, al N de Zoh Laguna, selva mediana subcaducifolia-subperennifolia de Brosimum alicastrum, Protium copal, Platymiscium sp., con mucha Cryosophila argentea, $230 \mathrm{~m}$ s.n.m.; planta vigorosa a la orilla del chilar; dos flores abiertas, $12.4 \mathrm{~cm}$ de diámetro, cerraron cerca de las 12:30; 3 Eulaema se aproximaron a las flores, no se posaron. Fragancia especiosa, débil, no 
identificada, 16-IV-1995, M. Soto 7684 \& E. Martínez *AMO! AMO(in spirit)! Ejido El Refugio, selva inundable de Bucida buceras a la orilla de la laguna, no la hay en el bajo de Haematoxylon contiguo. 230 m s.n.m., 17-IV1995, M. Soto 7685 \& E. Martínez *AMO(x2)! 200 m, $18^{\circ} 35^{\prime} \mathrm{N}, 8^{\circ} 24^{\prime} \mathrm{W}, 1$ Feb 1076, P. Alvaro $M \&$ G. Bacao 173 MO. QUINTANA ROO: Dense forest near shore of lagoon Chichankaná, on shrubs. N part of lagoon, $88^{\circ} 43^{\prime} \mathrm{N}$, $19^{\circ} 52^{\prime}$ W, ca. 50 m, 16 Aug 1935, O. Nagel sub E. Oestlund 4973 *AMES(51850, sterile)! *MO(1145555; sterile) *US(1805110; sterile). Mpio. F. Carrillo Puerto, camino al Ejido X'konha', 4 m s.n.m., lat. $19^{\circ} 28^{\prime} \mathrm{N}$, long. $88^{\circ} 03^{\prime} \mathrm{W}$, selva mediana perennifolia primaria, cálido húmedo, suelo pedregoso de color negro con mucha materia orgánica, asoc. con árboles, es epífita, abundancia regular, bejuco, $10 \mathrm{~m}$, perenne, tallo suculento, flor blanca, 8-V-1981, J.S. Flores, E. Ucán $8236 \mathrm{CICY} *$ XAL! En C. Vallarta, a $17 \mathrm{~km}$ al oeste de Puerto Morelos. Bejuco herbáceo con botones florales. Selva mediana con Manilkara, Vitex y Thrinax, 17 de abril de 1983, E. Cabrera 4611 y H. de Cabrera *AMO! MEXU! [cf., sterile] A $16 \mathrm{~km}$ al S de la terminal del Ferry, cerca de la entrada a Palancar, selva baja a mediana con abundante Lonchocarpus, Dalbergia etc., suelos inundables, epífita sobre tronco, 22/Nov/1982, E. Cabrera 9768, O. Téllez, y E. Linares MEXU(421555)! La Pantera, 1997, Carnevali s.n. AMO(sterile)! YUCATAN: San Antonio, Rancho al sur de Pixoy, lat. $20^{\circ} 42^{\prime} \mathrm{N}$, long. $88^{\circ} 14^{\prime} \mathrm{W}$, alt. $22 \mathrm{~m}$ s.n.m., selva baja caducifolia, secundaria, en la orilla de una mensura, suelo moreno, pedregoso; abundancia regular, hierba, $6 \mathrm{~m}$, perenne, fruto verde; obs. provoca comezón en la piel, 12-081983, E. Ucan 2761 CICY *XAL(fruto)! Mpio. Valladolid, Ebtún cabecera rumbo a Pixoy, lat. $20^{\circ} 41^{\prime} \mathrm{N}$, long. $88^{\circ} 14^{\prime} \mathrm{W}$, alt. $22 \mathrm{~m}$ s.n.m., selva baja caducifolia, secundaria, en la orilla del camino, suelo moreno, abundancia regular, hierba, $6 \mathrm{~m}$, perenne, flor verde amarilla, 11-05-1983, E. Ucan 2463 *XAL! GUATEMALA: IZABAL: [sterile] climbing on dry pine slope; leaves coriaceous, dull green above, paler dull green beneath, stems dull olive-green, warty rugulose, with a sulcation on each side, between Milla 42.5 and ridge, 6 miles from Izabal, Montaña del Mico, 65-800 m altitude, April 1, 1949 J.A. Steyermark 38539 F(1043863)![cf., fruit] A $8 \mathrm{~km}$ al NO de El Estor, $210 \mathrm{~m}$ s.n.m., hierba trepadora con fruto, sabana,30 agosto 1988, E. Martínez 23348 \& D. Stevens MEXU(480867)!MO(3656561)!Punta Palma, Sto. Tomás, $100 \mathrm{~m}$ de la entrada de la playa por el lado norte, 3 ó 4 plantas en la playa, 22 febrero 1998, M. Dix sub M. Soto 8611 AMO! ALTA VERAPAZ: [cf., sterile] Climbing, stems terete, deep green, savanna north of Concepción, 3-5 miles southeast of Finca Yalpemech, near Alta VerapazPetén boundary line, alt. 100-110 m, March 23, 1942, J.A. Steyermark 45233 *AMES(sterile, 63988)! F(1195510)! BAJA VERAPAZ: [cf.] Jocoló, climbing up trees, wild species of Vanilla, fruits said to be short, used as flavoring,
100 ft, Jan 30 1921, H. Johnson 1178 AMES(22753, sterile, perhaps V. cribbiana)! PETEN: "Vainilla", fleshy vine, Tikal National Park, Bajo de Santa Fé, salida de Arroyo Corriental, in tintal on Aguada Términos road, March-June, 1959, C.L. Lundell 15940 *LL(fruit)! same data C.L. Lundell 15818 *LL(fruit)! BELIZE: COROZAL: Maskall, Dec. 1933, P. Gentle 1063 *AMES(40496, sterile)! NY(fruit)! TOLEDO: "Vianilla", vine, in cohune ridge, Cañada HillAlta Vista Road, November 2, 1953, P.H. Gentle 8054 *LL(fruit)! NICARAGUA: ZELAYA: Cerro Waylawas, $10 \mathrm{~km}$ south of Siuna; elev. $250 \mathrm{~m}$. Vine; scrambling over rocks; leaves thick, fleshy (sterile). 5 June 1978. D. Neill $4219 \mathrm{SE}(049333)$ !

\section{Vanilla martinezii Soto Arenas, sp. nov.}

TYPE: GUATEMALA: IZABAL: Mpio. Livingston, El Golfete, a $20.4 \mathrm{~km}$ al NE de Río Dulce por lancha camino a Calix, bejuco herbáceo, flor verde con amarillo y labelo blanco; selva mediana perennifolia 'swampo', $15^{\circ} 47^{\prime} 06^{\prime}$ 'N, 88 51'42”W; E. Martínez S. 36410 y D. Alvarez, holo. MEXU!, iso. AMO! BIGUA! MO!

Vanillae inodorae similis sed foliis membranaceischartaceis, inflorescentia brevis laxa quasi sub sessili, bracteis viridis non foliaceis, floribus majoribus, sepalis rectis, petalis undulatis, labello subintegro vel quinque lateribus, fere longo quam lato, carinis humilibus inconspicuis ornato.

Hemiepiphytic vine, leafy, up to $10 \mathrm{~m}$ high. Stems terete-subquadrate, somewhat keeled (in dried condition), ca. 2-4.5 mm thick; internodes $3.9-7 \mathrm{~cm}$ long. Aerial, free roots pale brownish, dorsiventrally compressed, 2-3.3 cm long, ca. $1 \mathrm{~mm}$ wide. Leaves petiolate, the petiole up to $16 \mathrm{~mm}$ long, canaliculate; blade elliptic, acuminate, base obtuse, somewhat conduplicate; membranaceous-chartaceous (in dried condition), 7.5-21 x $3.5-7 \mathrm{~cm}$. Inflorescence strongly disimilar to the vegetative shoots, $26-50 \mathrm{~mm}$ long, a short, lax, 4-6-flowered raceme (rarely branched at base), subsessile, the peduncle up to $13 \mathrm{~mm}$ long, the rachis zigzag, at least ca. $3 \mathrm{~mm}$ thick, flowers separated by $9-14 \mathrm{~mm}$; with 1-2 peduncle bracts, clasping, ovate, concave, up to $10 \times 7 \mathrm{~mm}$. Floral bracts ovate, concave, obtuse to acute, apparently thin, 4-17 x 2-6 $\mathrm{mm}$. Flowers successive, apparently 2 open at once, very showy, with rather spreading segments, tepals yellow green, lip white, ca. $5.5 \mathrm{~cm}$ high, $6.5 \mathrm{~cm}$ wide. 


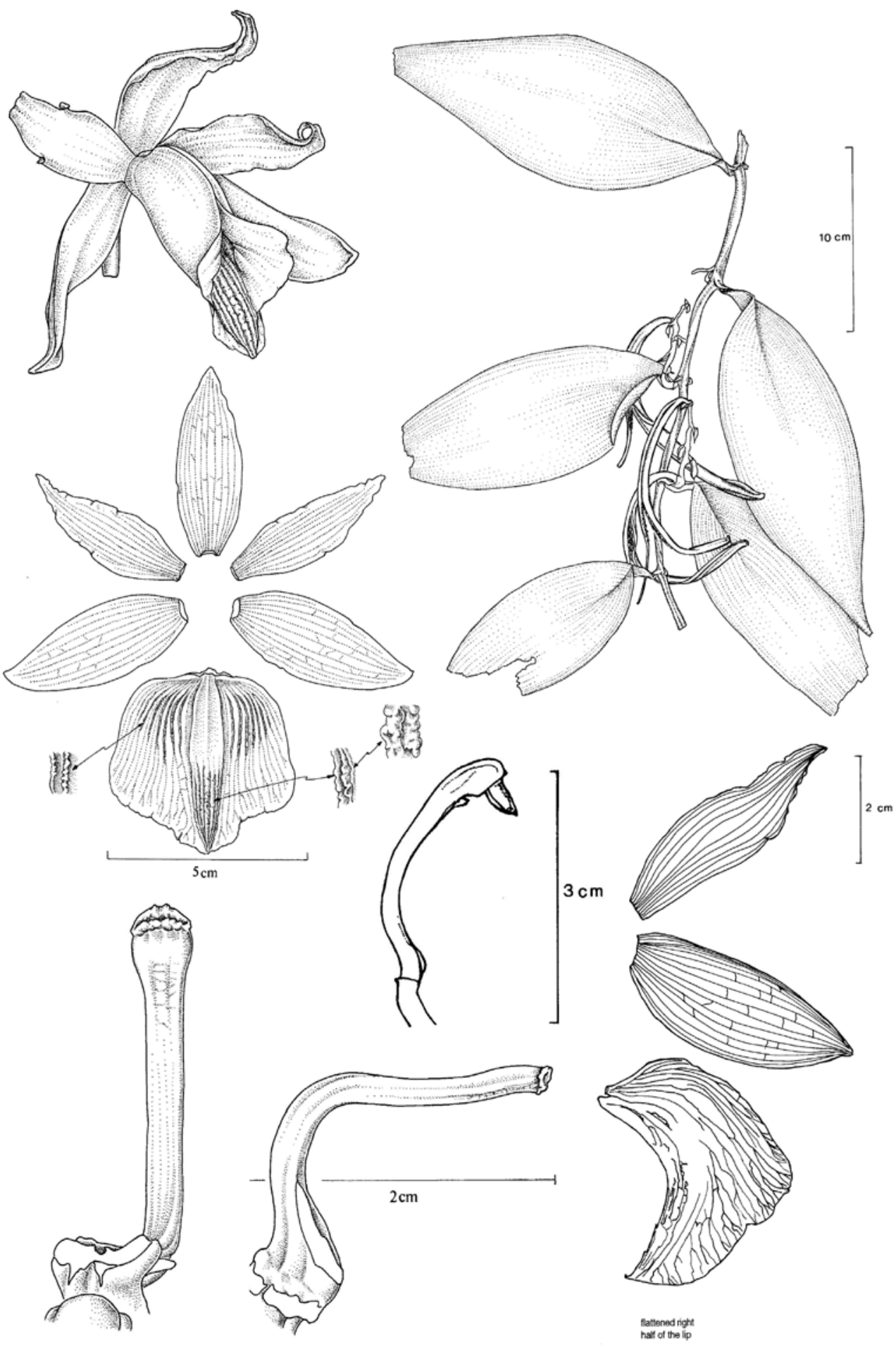

FiguRE 10. Vanilla martinezii Soto Arenas. Based on the type, E. Martínez 22790, and M. Soto 8602a. Drawing by M. López and M. Soto. 
Ovary terete, smooth, arcuate to straight, 2-sulcate, the grooves almost straight, $52-53 \mathrm{~mm}$ long, $4 \mathrm{~mm}$ thick. Dorsal sepal lanceolate elliptic, apex acute, base obtuse, basally and apically grooved on the abaxial surface, obscurely and broadly keeled at the middle, margins thinner, somewhat reflexed and slightly undulate along its entire length, fleshy, incurved at apex, concave at middle, ca. 11-veined; $45 \times 14.5 \mathrm{~mm}$. Lateral sepals very slightly oblique, elliptic, the upper margin may be or not almost straight, acute to obtuse at apex, almost subcalyptrate, slightly recurved and curved upwards; basally obtuse, slightly canaliculateconcave, broadly keeled on the abaxial surface, the keel narrower and higher at apex, smooth, margins thinner, minutely inflexed, almost entire and just slightly undulate, little pleated to straight, ca. 11-veined, 46$47 \times 17-18 \mathrm{~mm}$. Petals arcuate, obliquely elliptic to lanceolate, somewhat arcuate upwards, apex long acuteacuminate, recurved-rolled, base acute, subtruncate, conspicually grooved all length of the abaxial surface, ca. 10 veined, margins undulate and pleated, especially near the apex, 43-47 x 11-13 mm. Lip fused basally to the column ca. $7 \mathrm{~mm}$, arcuate, funnel-shaped, the lateral lobes-margins erect and forming a gullet around the column, the apical lobe-margin deflexed; impossible to flatten without some distortion, subentireobscurely trilobed, trapezoidal-subpentagonal to suborbicular-subpentagonal, base truncate with widely rounded 'shoulders', apex truncate-rounded, minutely mucronate, appearing triangular in natural position, axially grooved on the abaxial surface; 42-44 x 44-47 $\mathrm{mm}$, ca. 27-34-veined, veins branched above the middle; callus lip length, made up by a broad, $7 \mathrm{~mm}$ wide, flat, fleshy plate constructed by 3 obscure keels from the base to near the middle, progressively becoming ovate-triangular in cross section and then divided in ca. 11 low, sinuous, rugose-warty, inconspicuous keels reaching the apex as a narrow high, almost smooth keel; the lateral ca. 10 veins (on each side) slightly raised and minutely rugose-warty; lateral lobes-margins almost entire, and apparently somewhat reflexed, apical lobe margins slightly undulate-pleated. Column relatively short, strongly arcuate, the basal part forming a rather abrupt $60^{\circ}$ angle with the apical part, semiclaviform, apex dilated, smooth, ca. $28 \mathrm{~mm}$ long (across de arch); vertical wings oblong, inconspicuous, $4.5 \times 1 \mathrm{~mm}$. Anther strongly attached to the clinandrium by a broad, short filament, ovoid, ca. 4.5 long, $2 \mathrm{~mm}$ wide. Stigma a cavity, the midlobe concave, oblong, perpendicular to the column axis. Fruit clearly dehiscent, opening by 2 sutures, leaving unequal valves, 2-3 and 7-10 $\mathrm{mm}$ wide respectively, non-aromatic except by a resinous faint smell, dark brown, blackish inside, with ellipsoid seeds with slightly warty surface; $9.5-15 \mathrm{~cm}$ long, $6-8 \mathrm{~mm}$ thick before dehiscence. Fig. 10.

DistRIBUTION: Known only from eastern Guatemala, but also to be expected from adjacent wet areas of Belize and Honduras. It may also be native to Mexico. DNA from a sterile specimen of a membranaceous Vanilla collected in Crucero Corozal, in the Selva Lacandona, Chiapas, Mexico, A. Ibarra P. 2222?, was sequenced (ITS, matK), and it shows a strong relationship to $V$. martinezii, yet it seems different from the sympatric $V$. inodora; we suppose that it belongs to $V$. martinezii, although its sequences are somewhat divergent from the Guatemalan material. This locality is known to have populations of very thermophilous plants, that are very rare in other rain forest areas of Mexico (e.g. Lacandonia schismatica, Chysis limminghei, Warrea costaricensis, Ligeophila clavigera, Specklinia haberi, Maxillaria alba); furthermore the substrates in this area are partially flooded and with peat-like soils.

ECOLOGY: In lowland, wet, swampy areas of high rainfall. Locally abundant. Flowering in February and July. As far as we know, this vine grows only on islets in the delta of the Polochic River into Lake Izabal and similar habitats near the coast in the area known as Golfete; its habitat could be very specific, since these islets have an unusual peat-like soil. In the only flower that we have examined, the midlobe of the stigma is perpendicular to the column body, and the anther is also protruding. The fruit set in Vanilla martinezii is very high (up to $53 \%$ in a clone) which suggests that it could be self-pollinated.

Vanilla martinezii is known only from two or three nearby localities. Vanilla martinezii is a species of the membranaceous group; which, together with $V$. costaricensis, $V$. inodora, and $V$. sarapiquensis, are the only members of this clade in Mesoamerica. It is different from other species by the following combination of characters: membranaceouschartaceous leaves, short, lax, almost subsessile inflorescences (strongly different from the vegetative 
shoots); short, non-foliaceous bracts, large flowers with straight sepals, undulate petals, and by the huge subentire to subpentagonal, free lip, about as long as wide, and with very low and inconspicuous axial keels. Both $V$. costaricensis and $V$. inodora have elongate inflorescences similar to their vegetative axes, and leaflike bracts. Vanilla inodora is also easily distinguished by its cushion-like, axial callus and its emarginate lip; V. costaricensis is more similar to $V$. martinezii, but has smaller flowers, twisted-undulate sepals, and the lip surface is adorned with a rugose sculpturing, especially at the sides of the lip.

The most similar species is V. guianensis Splitgerber, from Guyanas and Amazonia (better known by its synonyms $V$. acuta Rolfe and $V$. latisegmenta Ames \& Schweinf.). Both have membranaceous-chartaceous leaves, short, few-flowered inflorescences with small, non-foliaceous bracts, subentire lip which is strongly veined, and similar column morphology with basal wings. However, in Vanilla martinezii the axial keels of the callus are warty, numerous, and not well-defined at the apex, some of them extending to the basal, lateral sides of the lip and the latter is not as trilobed at apex; in $V$. guianensis the callus is formed by 5 basal keels and 3 rather prominent ones, but it is not or only scarcely verrucose, and the lip apex is trilobed.

Vanilla martinezii seems to be another endemism of the wet lowlands around Lake Izabal, a site which has been proposed as a primary refuge for a diverse tropical rain florest biota (Toledo, 1982; Wendt, 1989, 1993). Its affinities with the Amazonian V. guianensis make its distribution even more interesting.

OTHER RECORDS: GUATEMALA: IZABAL: Creek Lagarto, Ensenada de los Lagartos, El Estor, 2 m s.n.m., bejuco, flor blanca, selva mediana perennifolia inundable, 16 julio 1988, E. Martinez 22790, P. Tenorio, H. Droege \& M. Díaz MEXU(480869)! Lago Izabal, desembocadura del Río Polochic, Creek Lagarto, al SW de El Estor, selva mediana inundable con Pachira aquatica, sobre suelos con mucha materia orgánica (peat), con Epidendrum stamfordianum, E. flexuousum, E. cardiochilum, E. raniferum, Oncidium sphacelatum, O. luridum, Pleurothallis marginata, $P$. sertularioides, Maxillaria crassifolia, M. elatior, Gongora aff. quinquinervis, Coryanthes picturata, Myrmecophylla brysiana, Sobralia decora; cerca del nivel del mar, ca. $15^{\circ} 28^{\prime} \mathrm{N}, 89^{\circ} 23^{\prime} \mathrm{W}$; común, hasta de $10 \mathrm{~m}$ de alto; 24 febrero 1998, M. Soto 8601a AMO! mismos datos, 23 cápsulas de 43 flores, M. Soto 8602 a AMO!
The next specimen from a nearby locality is sterile, but it matches $V$. martinezii in vegetative aspect; however it could be $V$. inodora Schiede, usually with broader leaves: IZABAL: Vicinity of Quiriguá; altitude 75 to $225 \mathrm{~m}$, May 15-31, 1922, P.C. Standley 24554

10. Vanilla odorata C.Presl, Reliq. Haenk. 1: 101. 1827 [1830].

TYPE: [ECUADOR:] Hab. in Guayaquil, Haenke, holo. PR(305753)! iso. (x2; 305751,305752) [all sterile and mounted with fragments of a Dimerandra species].

V. ensifolia Rolfe, Kew Bull. 1892, p. 141. Syntypes: [COLOMBIA:] Cauca, Peñol, Aout, Goudot, K! [with a drawing of the other syntype, "Leaves, flowers \& seed of Vanilla -- Patia, presented by Mr. J. Hanbury 1884" Herb. Pharmaceut. Soc.]; P(flowers poorly preserved)!

Epidendrum vermifugum Sessé \& Moc., Fl. Mex. ed. 2: 201. 1894.

Lectotype: (Soto Arenas, 1994): "Epidendrum vermifugum, Sessé, Mociño, Castillo \& Maldonado (4358) MA [sterile]!; isolectotype "Epidendrum vermifugum de México absque foliis" [only floral buds, mounted with "Epidendrum uniflorum"], BM! F(848611)!

Common names: "vainilla Tlatepusco" (Usila, Oax.); "Vainilla de Teutila", Humboldt.

Hemiepiphytic vine, branching, leafy, up to $6 \mathrm{~m}$ high. Stems flexuose, terete, smooth, dark green, with whitish dots, 4-6 mm thick; internodes 7-10.5 cm long. Terrestrial roots conspicuously pubescent; aerial, free roots terete, green to pale green, $1 \mathrm{~mm}$ thick; attaching, aerial roots strongly flattened. Leaves subsessile; the blade lanceolate to ensiform, very narrow, sometimes oblique, acuminate to long acuminate at apex, very dark green on both surfaces, $8-13 \times 1.5-2.7 \mathrm{~cm}$; ca. $1.8 \mathrm{~mm}$ thick in fresh. Inflorescence a 6-12-flowered raceme, rachis $30 \mathrm{~mm}$ long, $6 \mathrm{~mm}$ thick. Bracts subsessile, concave, membranaceous, subsessile, progressively smaller, ca. $8 \times 5 \mathrm{~mm}$. Flowers successive, 1-2 open at once, with spreading segments, ephemeral (from 7:00 to 16:00 hrs), showy, tepals whitish green, translucent, lip greenish white, the throat striped with pale yellow lines, callus white, column white; ca. $8 \mathrm{~cm}$ high, $7 \mathrm{~cm}$ wide; 


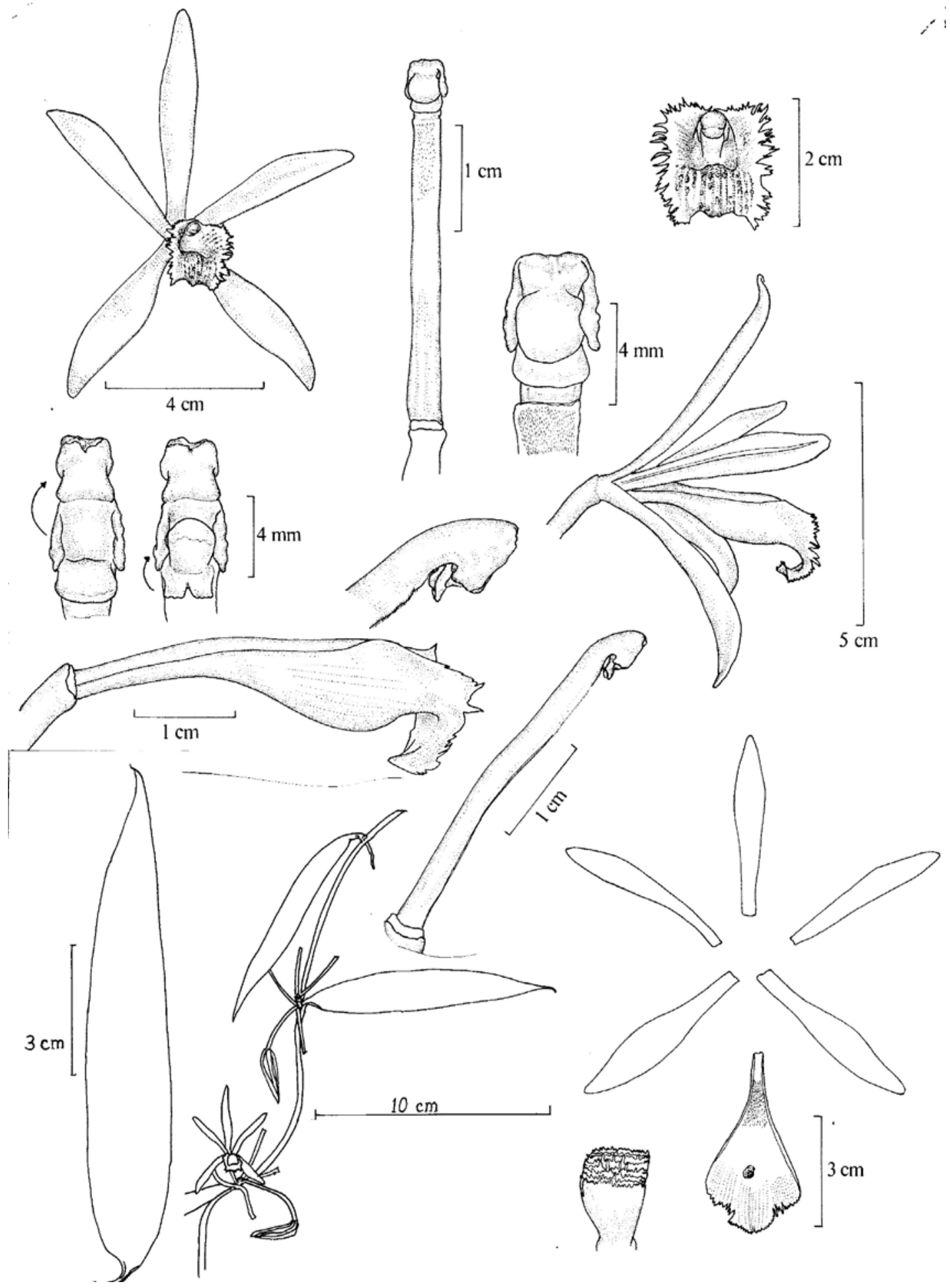

FiguRE 11. Vanilla odorata Presl. Based on M. Soto 6617. Drawing by R. Jiménez. 
fragrance weak, green, fresh. Ovary terete, smooth, ca. $3 \mathrm{~mm}$ thick. Dorsal sepal linear to oblanceolate, apex acute, rounded, subcalyptrate, base attenuatesubunguiculate, concave, 9-veined, 47-54 x 8.0-8.3 mm. Lateral sepals narrowly elliptic to oblanceolate, oblique, apex subacute, rounded, subcalyptrate, base attenuatesubunguiculate, concave, ca. 12-veined, 44.5-52 x 9.5 $\mathrm{mm}$. Petals obliquely linear to oblanceolate, somewhat arcuate, apex obtuse, rounded, sometimes emarginate, oblique, fleshy, slightly calyptrate, base long attenuate; concave; with a very conspicuous, axial, elevated, flat, keel at the abaxial surface, ending in a cylindric, free, adpressed process, ca. $1 \mathrm{~mm}$ long; ca. 11-veined, 46-53 x $7 \mathrm{~mm}$. Lip attached to the column along the margins of the basal half (ca. 23-29 mm), tubular, cymbiform, the apex abruptly deflexed; axially grooved on the abaxial surface, the groove well-defined and deep; when spread out 42-49 x 19-26 mm; long unguiculate, the claw dense papillose at base and apex on the the inner surface, the papillae digitiform, unicellular, 13-14 x 2.7$3 \mathrm{~mm}$; the blade obovate-flabellate in outline, obscurely trilobed, ca. 20-veined, the veins branched in the distal third and slightly thickened; the lateral lobes narrow and obliquely obovate, margins long lacerate-fimbriate (cilia 1-3.5 mm long), ca. $25 \times 8-9 \mathrm{~mm}$; midlobe approximately subquadrate-semiorbicular, the margin undulate-crispate, laciniate, obscurely emarginate, 7-9 x 7-11 mm; penicillate callus at $29 \mathrm{~mm}$ from the base, 3-4.5 $\times 3 \mathrm{~mm}$; made up by ca. 9 imbricate, flabellatepraemorse, retrorse, laciniate scales, sometimes united each to other along the lateral margins, with some adpressed processes on the surfaces; continuous towards the lip apex with 3 inconspicuous keels, progressively thickened, less defined, and more confluent at apex, almost forming an apical, fleshy cushion, ca. 14-15 $x$ $2 \mathrm{~mm}$, with 3-4 conic, prominent, retrorse papillae and many small, elongate warts; other warts on the veins of the lateral lobes. Column very elongate and slender, semicylindric, 33-38.3 mm long, $2 \mathrm{~mm}$ wide; ventral surface flat and papillose, the papillae digitiform, septate, bigger towards the apex, absent at the basal third; apex dilated, with vertical wings, inconspicuously trilobed, ca. $2 \mathrm{~mm}$ long, $3 \mathrm{~mm}$ wide; clinandrium prominent, transversely oblong, concave, ca. $2 \times 3 \mathrm{~mm}$. Stigma trilobed, the lobes emergent; rostellum a flabelliform, somewhat convex blade, ca. $2 \times 3 \mathrm{~mm}$, covering and parallel to the lateral lobes, quadrate, slightly divergent each to other, ca. $1 \times 1 \mathrm{~mm}$. Anther versatile, attached to the clinandrium margin by a laminar, broad filament; body urceolate in outline, with 2 upper, ovoid, small, divergent lobes; $3 \times 2.5 \mathrm{~mm}$. Fruit narrowly cylindrical, slightly compressed, attenuate at apex, dark green, 17$17.5 \mathrm{~cm}$ long, 8-10 mm thick; strongly fragrant, aroma similar to that of $V$. planifolia. Fig. 11.

Distribution: Mexico (Veracruz, Oaxaca, Tabasco, and Chiapas), Guatemala, Belize, Honduras, Nicaragua, Costa Rica, Panama, Colombia, Ecuador, Peru, Bolivia, and probably Brazil.

Ecology: This species can be common in secondary vegetation derived from tall, evergreen, tropical forest and rainforest, in gaps or in slopes with cleared canopy in primary forests. It is known from the sea level to $650 \mathrm{~m}$ altitude. Flowering time is mainly in April and May, but the vanilla growers in the Oaxacan Chinantla mention other sporadic flowerings in August and November. The flowers remain open until 2:30 P.M.

The narrow, lanceolate to ensiform, long acuminate leaves, thin stems, translucent whitish-green tepals, white-greenish lip with the throat striped with pale yellow and the laciniate margins of the lip are characteristic. Vanilla insignis is very similar, but it has thicker, sulcate, rugose-papillose stems, broader, xeromorphic leaves, and the retrorse appendages of the callus are much more numerous, bigger and orange-yellow.

Mesoamerican specimens of $V$. odorata are very similar to that illustrated by Blanche Ames (Ames, Sched. Orch. 9: 1-6. 1925) based on Ecuadorian material and supposedly close to the type; perhaps the segments are slightly broader and the wings of the column have better-defined sinuses, and the laciniae can be shorter in the Ecuadorian and Colombian (e.g. Fonnegra et al. 1784) material. With these bases, the small differences do not seen to warrant the recognition of separate taxa.

Some specimens of Vanilla odorata from Belize have been identified previously in herbaria as $V$. hartii Rolfe, and a picture of $V$. odorata was labeled as $V$. hartii in "Native Orchids of Belize" (McLeish et al., 1995). Soto (1989) reported V. odorata from Mexico based on a specimen with buds from Quintana Roo (Cabrera $4611 \&$ Cabrera), but that specimen actually belongs to $V$. insignis.

Humboldt cited a "vanilla de Usila". From his 
description it seems that the involved species was $V$. odorata, which is well-known by the Chinantecan Indians of the region, and grown on a small scale at the present time.

At the beginning of the 19th century some vanillas were used as vermicide in Mexico and Cuba, and that is probably the origin of the Sessé and Mociño name. In the same way, the name "lombricera" was applied to some vanillas in Cuba (Boldó \& Estévez, 1990).

Vanilla odorata produces aromatic fruits, similar to those of V. planifolia, with a strong, pleasant fragrance; they are very much appreciated in the regions where the species is wild. In Chiapas they are occasionally used to flavor rums; in this area the species is much more common than $V$. planifolia, and actually it is the only vanilla collected for its beans in the Selva Lacandona, as in many other areas of Tropical America. In northern Oaxaca the species is grown as a curiosity in the plantations, intermingled with V. planifolia; the growers mention different cultural requirements from those given to $V$. planifolia, since it needs stronger sunlight. Although the fragrance is appreciated, the beans are difficult to manage, since they are attacked by fungi and because they dehisce if treated the same way as the fruits of $V$. planifolia; open fruits of vanilla usually bring a lower price. Vanilla odorata is found in dry to damp sites, usually in areas with higher rainfall than those of $V$. planifolia, and seems to be tolerant to a wide range of light conditions. Vanilla odorata is undoubtedly a species to be considered in any breeding program with commercial vanillas (see comments under Vanilla tahitensis, in "Excluded species").

OTHER RECORDS: MEXICO: VERACRUZ: [cf., sterile] "Vainilla". Vine on "Jimba" shrubs and on trunks of trees. Leaves leathery, glabrous. Common in some areas in dense forest, absent in others, Fortuño, Coatzacoalcos River, alt. 30-60 m, February 1937, L. Williams 8919 F(897099)! OAXACA: In sylvis umbrosis prope Lobani, Chinantla, Oajaca, Liebmann 6142 W(11759)! Tuxtepec, Ejido Chiltepec, "vainilla", domina Lonchocarpus, M. Sousa 947 MEXU [sterile]! Dto. Tuxtepec, Usila, Arroyo Iguana, vainillal de Silvano Bautista, ca. 250 m s.n.m., 24 abril 1992, M. Soto 6617 \& M. Hernández *AMO(x3; illustration voucher)! Dto. Tuxtepec, Mpio. San José Independencia, Cerro Clarín, en el extremo SW de la Presa Temascal, ca. 120 m s.n.m., 29 abril 1994, M. Soto 8829a \& U. Sánchez AMO! AMO(in spirit)! same data, abril 1994, U. Sánchez s.n. y $6 \mathrm{AMO}$ (in spirit)! Mpio.Valle Nacional, Arroyo de
Banco, vainillal del Sr.Lázaro Pérez Justo, 250 m s.n.m. con flores, muestreada para fragancia; menos atacada por plagas y patógenos que $V$. planifolia, 23-IV-1997, M.Soto 8501 \& M. Hernández *AMO(flowers, photos)! San Felipe Usila, en cafetal, "vainilla tlatepusco", 23, abril 1995, M. Hernández s.n. AMO(flowers in spirit)! km 49.8 del camino Sochiapa-San Juan Lalana, $1.2 \mathrm{~km}$ antes de San Juan Lalana, $210 \mathrm{~m}$ s.n.m. Cafetal derivado de selva alta perennifolia, en el fondo de cañada rodeada de encinares calientes. Terrenos de Galino Téllez, 18-III-1997, M. Soto 8115 \& A. Cibrián AMO(fruit)! Dto. Tuxtepec, Mpio. San José Independencia, Cerro Clarín, en el extremo SW de la Presa Temascal, ca. 120 m s.n.m., 29 abril 1994, M. Soto 7631 \& U. Sánchez AMO! AMO(in spirit)! CHIAPAS: alrededores del sitio arqueológico de Bonampak, vegetación secundaria derivada de selva alta perennifolia, $350 \mathrm{~m}$ s.n.m., abril 1981, M. Soto 1001 AMO! Mpio. Ocosingo, km 5 del camino del Crucero San Javier a Bonampak, vegetación secundaria derivada de selva alta perennifolia, sobre suelos rojos arcillosos, ca. 350 m s.n.m. 26 junio 1996 M. Soto 7959 \& R. Solano $\mathrm{AMO}$ (fruit)! Mpio. Ocosingo: Estación de Biología Chajul, en el borde del Río Lacatúm; camino a Arroyo Miranda, selva mediana subperennifolia inundable sobre terrenos planos con Scheelea y Sabal, ca. 180 m s.n.m., muy escasa, 21 junio 1996, M. Soto 7950 y R. Solano AMO(sterile)! BELIZE: Trail through light jungle, near Camp 2. Alt. $2000 \mathrm{ft}$. Wiss (vine) with glossy green succulent leaves and stems. No flower or fruit seen. 20.8.1976. C. Whiteford 1316 MO(2584013)! GUATEMALA: IZABAL: [cf., sterile] Twining vine; leaves deep green, succulent; fruit green, thick and succulent, twisted, exuding clear thick liquid when crushed; faint vanilla odor. Quebradas, 19-22 May 1919, H. Pittier $8589 \mathrm{~A}$ NY! US(1013492); ALTA VERAPAZ: "Vainillita" Chirujija Oxec.; near the Finca Sepacuité, April 23, 1902, O.F. Cook \& R.F. Griggs 735 *US(408445)! PETEN: "Vainilla". Fleshy vine, Tikal National Park, Tikal, in botanal north of hotel, January 20, 1961 E. Contreras 1841 *LL(fruit)! La Libertad and vicinity, Aug.-Nov. 1933, M. Aguilar H. 164 *AMES(40519; steril)! HONDURAS: COLON: Capuchin site east, mangrove forest. $1.8 \mathrm{mi}$ strip on the north bank of rio Guaimoreto between old bridge and opening of Laguna Guaimoreto $4.5 \mathrm{mi} \mathrm{NE}$ of Trujillo on old road to Castilla. Lat. $15^{\circ} 57^{\prime} 30^{\prime \prime} \mathrm{N}$; Long. 8554'30"W. 2 Feb 1981, J. Saunders 1008 *LL(sterile)! *SEL(038496, fruit)! Lancetilla, 150 ft., Yuncker 4993 NY! NICARAGUA: SEGOVIA: E of Jalapa, elev. 1600 ft., May-June, A.H. Heller 6106 SEL(013289; 003851, drawing, fragments)! "Segovia Prov.", A.H. Heller s.n. F(1598348)! without data, A.H. Heller s.n. SEL(003851)! ZELAYA: [sterile]" Vainilla", bejuco, sobre árboles, Guamil de segunda clase. Area de Ocotal, Río Grande, Guamil o breñas sobre áreas pantanosas, a lo largo del Río Grande, Alt. 0-15 m, Abril 23, 1949, A. Molina 2312 
$\mathrm{F}(1364505)$ ! Cerro Waylawas, ca. $13^{\circ} 39^{\prime} \mathrm{N}, 84^{\circ} 48-49^{\prime} \mathrm{W}$, elev. ca. 100-268 m; sheer dog tooth limestone peak and plain on E side of peak. Pendant epiphyte, sterile. 16 March 1978. W.D. Stevens, B.A. Krukoff7385 SEL(049332; cf., steril)! COSTA RICA: ALAJUELA: Upala, San José, Alrededores de Laguna Las Camelias, $10^{\circ} 28^{\prime} \mathrm{N}, 85^{\prime}$ '08'W 100 m, bejuco trepador, 19 Nov 1987, G. Herrera 1346 INB(sterile)! MO(3709189)! LIMON: Hamburg Finca, on the Río Reventazón below Cairo, altitude about 55 meters. Large epiphytic vine; laeaves and fruit dark green. "Vanilla nevermanii", "Vainilla". Febr. 19, 1926, P.C. Standley \& J. Valerio No. 48917 *AMES(32665; fruits)! *US(1309433)! [cf.] Hamburg Finca, on the Río Reventazón, F. Nevermann s.n. *AMES(33060; poorly preserved flowers)! PANAMA: PANAMA: [cf.] Barro Colorado Island, 10 Jan. 1940, F.W. Hunnewell $16433 *$ AMES(sterile, 87907)! COLOMBIA: ANTIOQUIA: Hierba trepadora, tépalos externos verde amarillosos, internos amarillosos. Carretera MutatáPavarandó, entre Haciendas La Esperanza y Mocarí, 150 m s.n.m. Marzo 6 1987. R. Fonnegra, F.J. Roldán, J. Betancourt, B. Echeverry, O. Escobar $1784 \mathrm{~K}$ ! *MO(3592235)! PERU: LORETO: Leticia on the Amazon River, September 1929, L. Williams 3161 *AMES(43483; sterile)! Herbaceous vine. Yurimaguas, lower Río Huallaga; alt. about $135 \mathrm{~m}$; dense forest, August 23-September 7, 1929, E.P. Killip \& A.C. Smith 29065 *AMES(43484; old inflorescences)! BOLIVIA: IXIAMAS: Best kind here, fruit fragrant, vine, common, climbing over small trees in damp forest, $15-20 \mathrm{ft}, 1000-1500 \mathrm{ft}$ alt, Dec 13 1921, O.E. White 1115 *AMES(28024; fruits)! BENI: Rurrenabaque. Rank growing species; swamp woods, common. Fls. said to be white, fruits make good vanilla. 900-1000 ft alt., Dec 3, 1921, O.E. White 1821 *AMES(28026; old inflorescence)! REFERENCES: Ames, Sched. Orch. 9: 1-6, fig. 1. 1925; Schweinfurth, Orch. Peru, Fieldiana 30(1): 43. 1958; Hamer, Ic. Pl. Trop. pl. 1193. 1984; Soto Arenas, Orquídea (Méx.) 13(1-2): 295-300, figs. p. 296, 297. 1994.

\section{Vanilla phaeantha Rchb.f., Flora 48: 274. 1865.}

TYPE: Cuba, C. Wright 3351 W; AMES(71001, iso.)! $\mathrm{BM}$ (another specimen is $V$. cf. poiteai)! $\mathrm{G}(7889 / 109)$ ! K(iso.)!

Vanilla planifolia var. macrantha Grisebach, Vcat. P1. Cub. 267. 1866.

\section{Common names: "Tapia” (Panama).}

Hemiepiphytic vine, branching, leafy. Stems terete, smooth, green, 4-12 $\mathrm{mm}$ thick (in dried condition); internodes 8-15.5 cm long. Aerial, free roots, terete, pale brownish, up to $10 \mathrm{~cm}$ long, ca. 2 $\mathrm{mm}$ thick; attaching roots strongly flattened up to ca.
$5 \mathrm{~mm}$ wide. Leaves subsessile, the petiole twisted, canaliculate, up to $8 \mathrm{~mm}$ long; blade narrowly oblong to narrowly elliptic, base rounded-subcordate, apex acute-apiculate, chartaceous (xeromorphic), green, margins revolute, $10.3-19 \times 2.2-5 \mathrm{~cm}$. Inflorescence a 4-6-flowered raceme, 25-45 $\mathrm{mm}$ long, ca. 4-6 mm thick, peduncle 15-29 mm long, rachis, 11-15 mm. Flowers successive, 1 open at once, ephemeral, the segments spreading, at least $75 \mathrm{~mm}$ long; tepals greenish-white to cream, lip white stained with brownish at edges or orange-yellow. Ovary straight to arcuate, subterete, smooth, $42 \mathrm{~mm}$ long, ca. $4 \mathrm{~mm}$ thick. Dorsal sepal long oblanceolate acute-subacute, rounded at apex, subcalyptrate; base long unguiculate, attenuate, canaliculate, the claw ca. $24 \mathrm{~mm}$ long, ca. 3-4.5 mm wide, blade concave, ca. $10.5 \mathrm{~mm}$ wide, ca. 12 veined, smooth, thick and fleshy, total length, 62-74 mm. Lateral sepals strongly oblique, long oblanceolate, arcuate, apex acute, subcalyptrate and minutely warty on the apex of the outer surface; base long unguiculate, attenuate, canaliculate, claw ca. 22 x $5 \mathrm{~mm}$; blade concave, 12-12.5 mm wide, ca. 14 veined, smooth, thick and fleshy, total length 58-72 $\mathrm{mm}$. Petals long linear, arcuate, slightly sigmoid, apex subacute-obtuse, base long attenuate, canaliculateconduplicate basally the rest concave, with an elevated axial, flat keel on the outer surface, ending in a triangular, acute, terminal process ca. $1 \mathrm{~mm}$ long, ca. 10 -veined, thinner than the sepals, $61-73 \times 8.5 \mathrm{~mm}$. Lip attached to the column along the margins of the basal half (ca. $42-52 \mathrm{~mm}$ ), tubular, trumpet shaped, conspicuosly cymbiform, deepest near the middle, axially grooved on the lower surface, when spread out 62-72 mm; unguiculate, the claw canaliculate, with two rows of trichomes on the apical half, 26-34 $\mathrm{x}$ ca. $3 \mathrm{~mm}$; the blade flabellate, somewhat trilobed, margin slightly undulate, ca. 36-veined, apex emarginate; obliquely long obovate, rounded 30-33 x 12-14 mm; midlobe distinct, transversely oblong, the margins conspicuously reflexed, revolute, emarginate, $5 \times 11$ $\mathrm{mm}$; penicillate callus at $40-45 \mathrm{~mm}$ from the base, made up by ca. 12 congested, retrorse, aproximately trapezoidal, fimbriate scales, the scales regularly united each to other along the lateral margins, ca. $9 \mathrm{x}$ 5.5-6 mm, with an apical callus, low, inconspicuous, thickened. Column elongate, conspicuously sigmoid, 51-60 mm long; ventral surface lanuginose towards the 

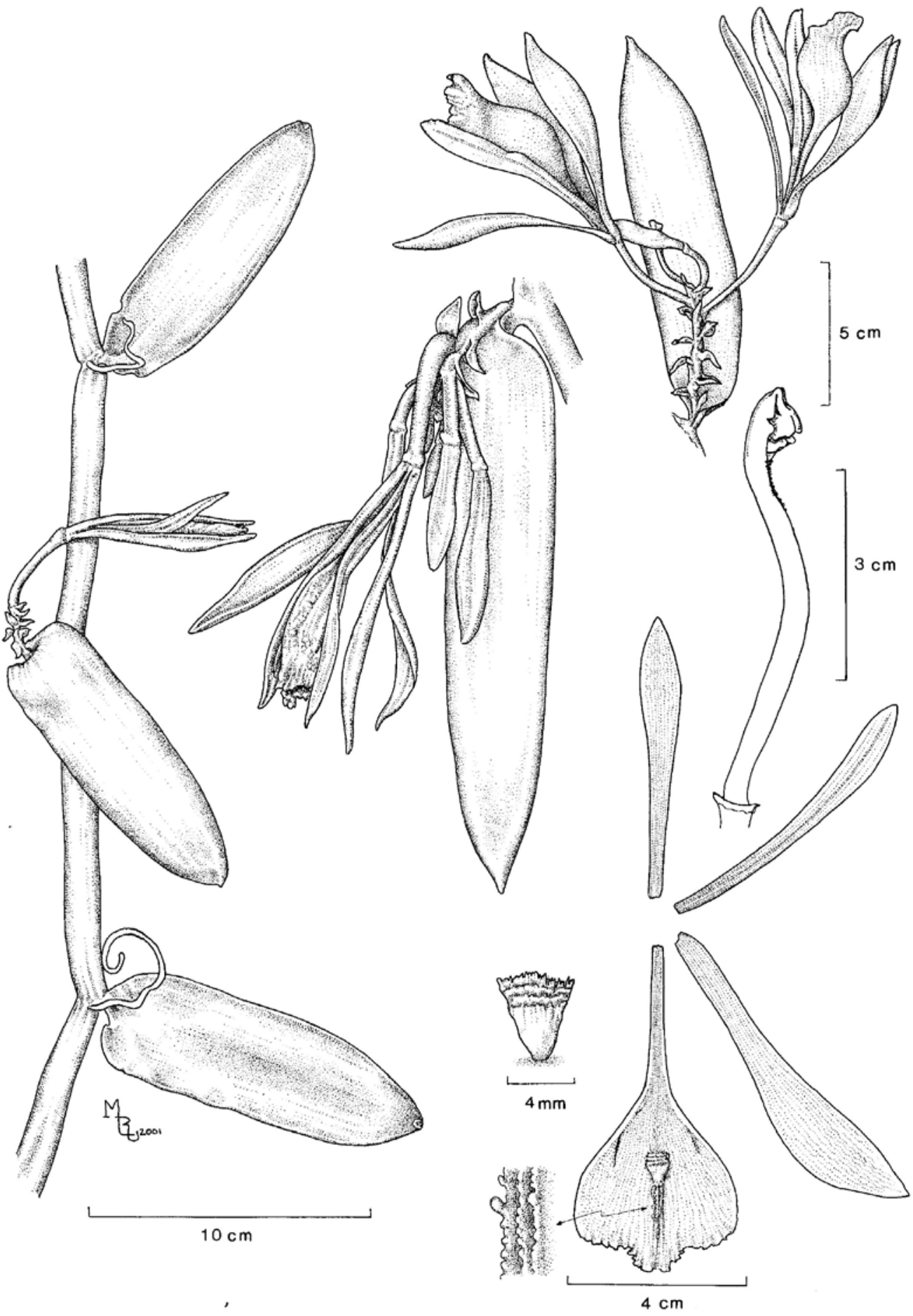

FiguRE 12. Vanilla phaeantha Rchb.f.. Based on R.S. Williams 588 (flower dissection), O.F. Cook s.n. SEL! (inflorescence with leaf) and C.W. Powell 412 (inflorescence with 2 open flowers); Dwyer et al. 4691 (column). Drawing by M. López. 
apex, below the stigma; apex dilated, vertical wings somewhat bilobed, the lower lobe falcate, ca. $2 \times 3.5$. Stigma trilobed, with a convex, midlobe, ca. $3 \times 4.5$ $\mathrm{mm}$, lateral lobes transversely oblong. Fig. 12, 16D.

Distribution: U.S.A. (Florida), Cuba, Lesser Antilles, Venezuela, Trinidad, Mexico (Yucatán and Quintana Roo), ?Costa Rica, and Panama. It is unknown if similar plants found in Ecuador, Guyanas and Brazil belong here or to $V$. bahiana.

Ecology: In Mexico this species grows in tropical deciduous or semideciduous forest near swampy areas, at about $100 \mathrm{~m}$ above sea level. Mexican specimens are juveniles and no flowering or fruiting specimens have been recorded. In Panama the species grows in coastal vegetation and in savannas with Curatella, Clethra, and Roupala.

A previous report of $V$. phaeantha from Central America was based on misidentified specimens of $V$. calyculata. Vanilla phaeantha is very common in the West Indies, but it has been scarcely recorded from the mainland, except from Florida. However, it reaches the coast of Venezuela (G. Carnevali, pers. com.), and also the Yucatan Penninsula and central Panama, in our study area. Mr. Neal Byrd, owner of Finca La Gavilana, Province of San José, Costa Rica, cultivates a Vanilla phaeantha that was apparently collected from the wild somewhere in Costa Rica. The only flowering specimens of this species that have been available to us are from Panama, where it seems to be common on the Pacific slope.

The oblong-elliptic, xerophytic, usually greenyellowish leaves are usually shorter than the internodes. The flowers are very large, with greenish tepals, and the lip is white with yellow stripes. It is related to $V$. bahiana Hoehne from Brazil. From the $V$. planifolia and $V$. odorata complexes it can be distinguished by its smooth disc.

OTHER RECORDS: MEXICO: YUCATAN: Cenote Mucul, Cerca de Sotuta, selva baja caducifolia, ca. 100 m s.n.m., G. Carnevali 4885 (cultivated specimen, not preserved, ITS sequence)! QUINTANA ROO: Mpio. Othón P. Blanco, Ejido Caobas, alrededores de la Sabana del Jaguactal, unos $21 \mathrm{~km}$ al sur de la carretera principal Xpujil-Chetumal, $A$. Cibrián 21, 23, R. Jiménez, G. Carnevali AMO(sterile)! COSTA RICA: LIMON: Guapiles, Los Diamantes, collected 26-12-2000, cultivated at Finca La Gavilana, Río
Savagres basin, $N$. Byrd $I I-A-1-5$ PANAMA: PANAMA: Vine climbering up trees in low thicket. Farfan Beach; roadside thicket adjacent to beach. 30 March 1969, J.D. Dwyer, L.N. Durkee \& J.R. Castillón 4691 *MO(1980689)! Balboa, "Tapia", alt sea level, grows out in much sunlight, sepals \& petals pale green; lip white with stain of brownish color at edge, flowers in April, 1924, C.W. Powell 412 *AMES(28219)! Ancon Hill, June 4, 1923, W.R. Maxon 6779 *AMES(33689)! *US(1180005)! Bismark above Panama, Fls. nearly white except greenish apex; climbing on trees several yards, March 12, 1908, R.S. Williams $588 \mathrm{NY!}$ *US(678159; det by Schlechter as V. pittieri)! Common, sea level, February 1924, epiphyte, Hort. Powell 137, C.W. Powell $3507 * \operatorname{AMES}(28290)$ ! Climbing vinelike on the Farfán Beach area, forward dune-high beach community, 18 June 1971, R.L. Lazor 5358 SCZ(2262; sterile)! Fort Clayton, Farfán Beach area, vine with fl cream, 29 May 1966, E.L. Tyson 4106 MO(1917579)! SCZ(2263)! [cf.] Moist thickets; herbaceous vine; leaves very fleshy. Along the old Las Cruces Trail, between Fort Clayton and Corozal, December 3, P.C. Standley 29103 AMES(31440, sterile)! [cf.] Brushy slope; large herbaceous vine, common, Tumba Muerto Road, near Panamá, January 6, 1924 P.C. Standley 29731 AMES(31439, sterile)! VERAGUAS: Carretera Panamericana, $4.3 \mathrm{~km}$ al W de El Higo, ca. $20 \mathrm{~km}$ al W de La Mesa, sabana de Curatella, Clethra y Roupala con selva riparia de Andira, Pithecellobium, Enterolobium y Acacia, bejuco con frutos jóvenes, extendido sobre algunos arbolitos de la sabana, hojas muy pequeñas, tallos delgados, M. Soto 9920 PMA(ITS sequence)! DOUBTFUL LOCALITY: CANAL ZONE or ALAJUELA. Photo, April 15, 1925 O.F. Cook *SEL(011359; specimen; 111357 photo, the photo in envelope is of a membranaceous species)!

12. Vanilla planifolia G.Jacks., in Andrews, Bot. Repos. 8: t. 538. 1808.

LECTOTYPE: West Indies, without proper locality. Introduced into England by the Marquis of Blandford and flowered in the collection of the Rt. Hon. Charles Greville. The plate 538 was prepared from Greville's specimen and was chosen as the lectotype (Garay \& Sweet, 1974).

Lobus oblongus aromaticus Clusius, Exoticorum Libri Decem.: 72. 1605.

Araco aromaticus Hernández, Thes. Rev. Med. Nov. Hisp.: 38, fig. 1651.

Myrobroma fragrans Salisb., Parad. Lond. 2: t. 82. 1807, nom. illeg.

Based on the same specimen that served as the type of $V$. planifolia G. Jackson. 
Vanilla fragrans (Salisb.) Ames, Sched. Orch. 7: 36. 1924; Stehlé, Fl. Descr. Antill. Fr. 1: 109. 1939; Portères, Enc. Biol. 46: 234. 1954.

Vanilla sativa Schiede, Linnaea 4: 573. 1829. Holotype: "Baynilla mansa HispanoMexicanorum". Hab. sponte Papantlae, Misantlae, Nautlae et Colipae inqque iisdem pagis colitur"; Schiede, May 29 [single leaf] $\mathrm{BM}$ !

Vanilla sylvestris Schiede, Schiede, Linnaea 4: 573. 1829.

Type: "Baynilla cimarrona, HispanoMexicanorum. Hab. Papantlae, Nautlae, Colipae", not located.

?Vanilla carinata Rolfe, J. Linn. Soc. London 32: 446. 1896. [or probably V. gardneri but the type is not useful]

Vanilla duckei Huber, Bol. Mus. Goeldi, Pará, 5(2): 327. 1908.

Type: A. Ducke GOELD.

Vanilla bampsiana Geerinck, Bull. Jard. Bot. Nat. Belg. 52: 345, fig. 1. 1982.

Type: Zaire, Bikoro: Lebrun 1459 BR!

Common NAmes: "Vainilla mansa", "vainilla" (Veracruz), "Xanat", "shanat", "caxixánath" (Totonaco, Veracruz), "vainilla colibrí" (Oaxaca), "tlilxóchitl" antique Nahuátl (Badianus manuscript), "Kuoley gm" (Chinanteco, Oaxaca), "zizbic" (Maya, Yucatán); “juju” (Tabasco).

Hemiepiphytic or rupicolous vine, much branched, leafy, up to $10 \mathrm{~m}$ high. Stems flexuous, terete, smooth, dark green, whitish dotted, sometimes the new stems covered with a whitish wax (Oaxacan plants), (6.5)11-12(13) $\mathrm{mm}$ thick; internodes $8-11 \mathrm{~cm}$ long. Terrestrial roots pubescent, $1.4-1.6 \mathrm{~mm}$ thick; aerial, free roots terete, $2.5-3.0 \mathrm{~mm}$ thick; attaching, aerial roots semiterete, flat on the surface in contact with the substrate, $3 \mathrm{~mm}$ wide. Leaves subsessile, the blade, elliptic, oblong, narrowly oblong, usually with parallel margins, abruptly acuminate to subacuminate, somewhat oblique (variable), upper surface deep to pale green, paler on lower surface, $9.5-23 \times 3.5-7.6 \mathrm{~cm}$, ca. $1.3-2.4$ $\mathrm{mm}$ thick in fresh. Inflorescence a 7-18(-70) flowered raceme, up to $26.5 \mathrm{~cm}$ long. Flowers successive, 1-2 open at once, segments variably spreading, most frequently the tepals ca. $40^{\circ}$ with respect to the column; ephemeral, showy, tepals pale green to whitish green, lip pale cream-yellow to yellow with ochre in the throat and papillae; ca. $62-64 \mathrm{~mm}$ high, $39 \mathrm{~mm}$ wide, fragrance weak, sometimes a cinnamon can be appreciated, herbal, or white (e.g. Hymenocallis-like). Ovary arcuate at base, upper part straight, terete, smooth, basally white, the rest green, with extrafloral nectaries, $57 \mathrm{~mm}$ long, 4 $\mathrm{mm}$ thick. Dorsal sepal narrow elliptic to oblanceolate, apex subacute, rounded, subcalyptrate, base attenuatesubclawed, slightly concave, canaliculate basally, ca. 9-veined, 55-60 x 10-12 mm. Lateral sepals obliquely narrowly elliptic, to oblanceolate, apex subacute, subcalyptrate, base attenuate- subclawed, almost flat, slightly canaliculate basally, margins slightly involute, ca. 10-veined, 54-60 x 12-13.5 mm. Petals obliquely long oblanceolate, somewhat arcuate, apex slightly reflexed, obtuse-rounded, oblique, notched, slightly thickened, base attenuate; concave, canaliculate at base; with a very conspicuous, axial elevated, flat keel at the abaxial surface, finishing in a cylindrical, free, ascending, free process, ca. $2 \mathrm{~mm}$ long; ca. 13-veined, $55-58.5 \times 10-11 \mathrm{~mm}$. Lip attached to the column along the margins of the basal half (ca. 31-35 mm), tubular, trumpet-shaped, very concave to cymbiform, slightly sigmoid, the apex abruptly flared, deflexed-recurved; opening subtriangular, $18 \mathrm{~mm}$ wide, axially grooved on the abaxial surface, the groove well-defined and deep; when spread out 49-55 x $24 \mathrm{~mm}$; long unguiculate, the claw pubescent, trichomes short, yellow to ochre, $15 \mathrm{x}$ $4 \mathrm{~mm}$; the blade obovate-flabellate, trilobed in outline, ca. 36-veined, the veins branched in the distal third, and slightly thickened; the lateral lobes obliquely triangularflabellate, margins widely undulate, denticulate towards the midlobe; teeth less than $0.6 \mathrm{~mm}$ long, ca. $27 \times 10.5$ $\mathrm{mm}$; midlobe approximately subquadrate-transversely oblong, emarginate to deeply bilobed, the margin undulate-crenate, $5 \times 9 \mathrm{~mm}$; penicillate callus at 30 $37 \mathrm{~mm}$ from the base, 5.8-6 $\times 4-4.5 \mathrm{~mm}$; made up by ca. 8 imbricate, flabellate-praemorse, retrorse, lacerate scales, pale yellow, the distal ones bigger, sometimes united each to other along the lateral margins, continuous towards the lip apex with 2 conspicuous rows of papillae, and 2-4 inconspicuous rows, apical papillae bright green. Column very elongate and slender, trigonous-semicylindrical, 39-42 mm long, 2.5 $\mathrm{mm}$ wide; with vertical, flabellate to obscurely lobederose, acute to rounded, membranaceous wings, $2 \mathrm{~mm}$ 
long, $4 \mathrm{~mm}$ wide. Stigma trilobed, the lobes emergent; midlobe a trapezoidal, convex blade; ca. $3 \times 2 \mathrm{~mm}$; covering and parallel to the lateral lobes, longitudinally oblong, slightly divergent each to other, ca. $1 \times 1 \mathrm{~mm}$. Anther versatile, attached to the clinandrium margin by a laminar, broad filament; body ovate-cordiform, 3 x $3 \mathrm{~mm}$. Fruit straight to strongly arcuate, cylindricalsubclavate, thickened towards the apex, often 2-3 conspicuously sulcate in wild specimens; smooth in cultivated and many wild specimens; 10-30 cm long, 7-10 cm thick. Fig. 16E-F, 17D.

Distribution: Imperfectly known. Mexico (Veracruz, Oaxaca, Chiapas, Tabasco, Quintana Roo, and probably escaped in Yucatán and southern Oaxaca), Guatemala, Belize, Honduras, and Costa Rica. It is unknown if the plants in other areas are native or escaped from cultivation. For example, in Panama it is known mostly from Barro Colorado Island and San Blas Province, perhaps an indication that it is escaped there.

The species seems to be escaped in Florida (cf. Luer, 1972), and in Jamaica (Fawcett \& Rendle, 1910), two areas well botanized by experienced collectors. Foldats (1969) indicated that the species is common in Venezuela, but did not cite records; neither did Garay and Dunsterville include it in their works on Venezuelan orchids. South American wild specimens previously identified as V. planifolia and others from elsewhere outside Central America have proven to be misidentifications. On the other hand, there are some collections from Ecuador that match closely the Central American, cultivated material. It is doubtful that $V$. planifolia is native in regions outside of Mesoamerica. Suposedly wild specimens of $V$. planifolia from Rio Palenque Center, Ecuador, have proven to be $V$. hartii.

The original distribution in Mexico is also uncertain. Northernmost, wild-collected specimens come from the region of Córdoba, in Central Veracruz, some hundreds of kilometers southwards from the area where the species supposedly was domesticated in northern Veracruz and Puebla. Most collections come from northern Oaxaca, where great morphological variation has been observed; a single record from southern Oaxaca, on the Pacific slope, has not been confirmed by recent collections. The species is very rare in Chiapas. There are several old collections from
Yucatán, in the xerophytic thorn scrub of the northern part of the peninsula; we suspect that they represent escaped, old relicts from cultivated plants, since this habitat is very different from the moister forests where it is wild at present.

ECOLOGY: Dwelling in tall tropical evergreen or semievergreen forests, from 150 to $900 \mathrm{~m}$, rarely to 1300 $\mathrm{m}$ altitude. The species seems to prefer moist forests, seasonally dry in spring, on calcareous terrain. It is absent in volcanic areas and in the wet tropical rainforests of Mexico. In moister areas it can be found in secondary, very young forests, or in large gaps. It flowers mainly in March to April, but varies from year to year, and flowering is rather gregarious in a region. Occasionally it flowers from February to May. Flowering seems to be a response to low winter temperatures, followed by strong sunny conditions in early spring.

Vanilla planifolia faces severe conservation problems in the wild. There are very few and scattered locations known at present; the largest populations in northern Oaxaca have been completely removed as a source of cuttings to establish new plantations; it is also almost extinct in Veracruz, where only two clones have been located in recent years. Only four isolated specimens have been located in Chiapas.

Vanilla planifolia is the vanilla of commerce, and the most widely planted species for its aromatic fruits.

The nomenclature of this species is very complex, since its history began before the Linnean system of nomenclature. The problem has been solved by Garay \& Sweet (1974), who lectotypified the species with a plate based on the original plant (leaving aside the statement of the identity of an earlier Plumier's polynomial); it seems pertinent to reproduce here their observations: “Jackson regards Plumier's unpublished drawing of "Vanilla flore albo, fructa breviori, corallino" as representing his $V$. planifolia. A study of this plate, however, convinces us that it represents Vanilla eggersii Rolfe. Salisbury based his Myrobroma fragrans also in Greville's cultivated specimen, but cited in synonymy Epidendrum rubrum Lam. Since in his publication Epidendrum rubrum is an integral part of the protologue, he should have made a transfer of Lamarck's epithet. It is of further interest that Salisbury equates or rather confuses Epidendrum rubrum Lam. with Plumier's polynomial description 
referable to Vanilla eggersii Rolfe." Therefore, the widely used name Vanilla fragrans must be rejected, because it was based on an illegitimate name.

The plate selected as the lectotype is not accurate enough to permit the recognition of the species; especially the much fringed lip suggests another species of the group, such as $V$. odorata or $V$. insignis. Hooker (1891) also expressed concern about the identity of this plate, and recognized the differences among Andrews' and Salisbury's plates. However, the same Greville's individual plant was illustrated and precisely described a year earlier by Salisbury, when he published his Myrobroma fragrans, the plate and description are much more accurate, and undoubtedly belong to the widely cultivated, "Mexican vanilla", discarding the possibility of it being another related species. The history of Vanilla planifolia has been reviewed by Dillon (1942) and Bruman (1948).

The published plate (Flore d'Afrique Centrale, pl. 39 ) of the recently described $V$. bampsiana Geerinck, from Zaire, is indistinguishable from our concept of $V$. planifolia. There are no vanillas with lamellose transverse callus, fimbriate margins, long unguiculate lips and papillose apices outside of Tropical America.

VARIATION AND CULTIVARS: Vanilla planifolia has proven to be somewhat variable in flower size, degree of flower opening, lip color, lip concavity, development of the lip papillae, intensity of fragrance, development of grooves on the fruit, self-compatibility, etc. This variation initially led us to consider the existence of more than one species involved; especially because of the uniformity of plants in cultivation (the cv. "mansa") compared with wild-collected specimens. However, it is possible that the narrow morphological variation seen in cultivated plants must be attributed to reduced genetic variation (Cibrian, Soto Arenas, ). Studies of gas chromatography indicate that the floral fragrance of different forms is composed primarily of the same compounds (1-2-dimethyl-cyclopentane, ethyl acetate, 1-8-cineol and ocimene-trans); 1-8-cineol especially is well known to be a strong attractant for euglossine bees. Since $V$. planifolia is pollinated by Euglossa viridissima and maybe other species of the same genus, the fragrant, attractive compounds can be considered as evidence for the specific integrity of all the known forms.
The growers in Veracruz recognize different types in $V$. planifolia, and these perhaps represent different genetic individuals (clones), since no genetic manipulation or breeding programs have been conducted in Mexico. These clones are better treated as cultivars.

cv. "mansa" or "dura"

This is the form widely cultivated in northern Veracruz, and probably in Africa and Asia; the plants from Asia (except the Philippines) and Africa are descendant of the original type specimen grown by Grenville and distributed to many botanic gardens during the 19th Century. It is unknown if more than one clone is involved, but the plants are very uniform in morphology. Different from many wild specimens are the non-sulcate fruits.

cvs. "acamaya", "rayada", and "variegata".

The stems and leaves have yellowish stripes, alternating with the common deep green of the other cultivars (see Roullet, 1990). There are at least two different genetic individual with variegated plants (Schlüter et al. 2007). There seem to be no differences in molecular markers between one of this clones and 'Mansa', suggesting that it can be a sport (due to somatic mutation).

cv. "albo-marginata"

A cultivar with beautiful leaves, margined with white (see Roullet, 1990). It has never been found in Mexico, and it is probably also a sport of Madagascan origin.

cv. "oreja de burro"

? Vanilla sylvestris Schiede

The cv. "oreja de burro" is occasionally grown as a curiosity in the plantations of the region of Papantla. It is very similar to the cv. "mansa", and difficult to distinguish except by experienced growers; the stems are slightly thinner, the leaves rather hanging, because the more elongate petiole, elliptic, abruptly acuminate, concave, with more prominent veins, and more greenish flowers. Once pollinated it forms a large fruit up to $30 \mathrm{~cm}$ long, usually bisulcate, but almost all the fruits are aborted in July, except sometimes when the pollen came from a different clone or from $V$. pompona; therefore, it is self-incompatible. Additional watering or feeding does not seem to maintain the fruits 
on the plant. The occasional fruits are longitudinally sulcate; it is probable that this cultivar was the base for Schiede's $V$. sylvestris, since the sulcate fruits are cited in the protologue.

It is said that the cv. "oreja de burro" grows faster and with more vigor than other cultivars of V.planifolia; furthermore the growers say that it is not severely affected by fungal diseases. Some of the indicated differences between "mansa" and "oreja de burro" are statistically significant (Castillo and Engleman, 1993); however, the vegetative propagation of vanillas in the plantations has made many of them genetically uniform, and it is very probable that the observed differences are among clones and not between different taxa (species, subspecies or varieties) or indicative of a genetic substructure in V. planifolia. The "oreja de burro" has a floral fragrance similar to the cv. "mansa" and it is also visited by Euglossa viridissima.

Cuttings of "oreja de burro" are sold occasionally by unscrupulous growers to discourage the establishment of new plantations. We have observed hectares of plantations that were nonproductive due to large quantity of vines belonging to the cv. "oreja de burro".

Several wild collected plants are notoriously different from the specimens cited above, and it is very probable that they belong to locally differentiated populations. Among them, there are several specimens collected in Belize that look somewhat different, with small leaves, and flowers with a poorly-defined midlobe of lip. These specimens have also rather elongate rachis and the flowering time is from December to April. Schipp S-971, M.A. Soto 8355, P.C. Standley 25064 are from Belize, Izabal, and Chiapas, from riparian habitats and they seem to be wild; however, leaf aspect is much more elliptic, and M.A. Soto 8355 has more greenish flowers and much longer fruits. DNA sequences of MAS 8355 is nested within the variation of $V$. planifolia, although with several autapomorphies, but we do not know if they represent only sequencing problems. Schlüter et al. have shown that V. planifolia has three rather different genetic groups, the cultivated group, the wild specimens from Mexico to Quintana Roo and the wild specimens from Costa Rica.

A specimen from Costa Rica [Esquinas forest. Area between the Río Esquinas and Palmar, sea level. May 2, 1950. Flowers pale green. P.H. Allen 5532 SEL
(011362)! ] is somewhat strange, the leaves are clearly petiolate and elliptic, acuminate, but not abruptly and the inflorescence is very dense with bracts smaller than typical. The flowers are not well-preserved, but the lip does not seem lobed, and the warts on the apex of the lip are very obscure. Our impression is that its morphology is intermediate between $V$. hartii and $V$. planifolia, and therefore it may be a hybrid.

Other RECORDS: MEXICO: VERACRUZ: Rancho El Coscolín, El Escolín, Cerro Grande, Mpio. Papantla de Olarte, 350 m s.n.m., $20^{\circ} 29^{\prime} \mathrm{N}, 9^{\circ} 33^{\prime} \mathrm{W}$, clima cálido seco, suelo arcilloso-arenoso, plantación de vainilla. Hierba trepadora de $2 \mathrm{~m}$, flor y fruto, abundante. Flores con la base del perianto amarillenta. Fruto con la base adelgazada. Aborta 50-100\% de los frutos. "vainilla oreja de burro", 25 Abr 1989, R. Castillo M 211 \& H. Cálix de Dios AMO(x2)! $\operatorname{MEXU}(678227)$ !

Other names applied in northern Veracruz, such as, "negra", "verde" or "amarilla" are apparently due to different exposure to light intensity.

OTHER RECORDS: UNITED STATES: FLORIDA: Dade Co. growing on trees in an extensive area in Cutler Hammock, on Biscayne Bay. Fls. greenish. May 15, 1976. D.S. Correll \& J. Popenoe 47216 NY! Brickell Hammock, Miami, Dade County, J.K. Small, 19 Feb-March 22, 1915, NY! MEXICO: SAN LUIS POTOSI: Tanjasnec, Mpio. San Antonio, bosque tropical perennifolio, dooryard, vine, "vainilla", planted, 4 May 1979, J.B. Alcorn 3006 *LL! MEXU! PUEBLA: Bejuco, fruto verde, "vainilla", en cafetal, fecundada por jicotes, Yancuictlalpan, Cuetzalan, el fruto seco se usa como aromatizante y saborizante de atole y otros alimentos, $F$. Basurto y R. Patrón 263 MEXU! VERACRUZ: Rancho El Coscolín, El Escolín, Cerro Grande, Mpio. Papantla de Olarte, 350 m s.n.m., $20^{\circ} 29^{\prime} \mathrm{N}, 97^{\circ} 33^{\prime} \mathrm{W}$, clima cálido seco, suelo arcilloso-arenoso, plantación de vainilla, hierba trepadora de $2 \mathrm{~m}$, flor verde amarillenta, abundante, "vainilla mansa o fina", fruto alimenticio y para condimento, $25 \mathrm{Abr}$ 1989, R. Castillo M. 210 \& H. Cálix de Dios AMO(x2)! MEXU(678228)! [cultivated] Predio Escolín, $12 \mathrm{~km}$ al NE de Papantla, 370 m s..n.m., trepadora, abundante, fruto verde, selva alta, secundaria, vainillal, suelo rendzina de color negruzco, 22 Junio 1987, A. García 3226 MEXU! [cultivated] Papantla de Olarte, $20^{\circ} 27^{\prime} \mathrm{N}, 97^{\circ} 19^{\prime} \mathrm{W}$, “vainilla”; usos, para hacer figuras de vainilla, F. Rosas C.I.P. $709 *$ XAL! [cf.] San Andrés Tuxtla, El Vigía, al E de Cerro Blanco, 28 May 1967, M. Peña 108 *AMES(11744, sterile)! Estación de Biología Tropical de Los Tuxtlas, ca. 200 m s.n.m., selva alta perennifolia, G.A. Salazar 2247 AMO(drawing)! AMO(exsiccata, en FAA)! Volcano San Martín, on trees in dense forest, 5 May 1936, 95¹1', 18³5', 600 m, J. González 
sub E. Oestlund 5790 *AMES(51851, sterile)! Mpio. Atoyac, a un lado de la vía del tren, cerca del puente, selva alta subcaducifolia de Bernoullia flammea y Dendropanax arboreous, terreno cárstico, sobre piedras y árboles, 2 mayo 1995, ca. 400 m altitud, M. Soto $7745 *$ AMO! Vainillal del Sr. Rafael Cardeña, Díaz Mirón y Río Nautla, Papantla, Veracruz. $180 \mathrm{~m}$ s.n.m. Muestreada para fragancia floral. 31-III- 1995. M. Soto 7648 AMO! [cf., fruit] A $800 \mathrm{~m}$ al norte de la casa de Genaro, ejido Vista Hermosa, Mpio. Tezonapa, $18^{\circ} 40^{\prime} \mathrm{N}$, $96^{\circ} 40^{\prime} \mathrm{W}$, alt. $500 \mathrm{~m}$, selva mediana subperennifolia, primaria, suelo oscuro, arcilloso, bejuco perenne, escasa, fruto verde, nom. vul. "vainilla", 4-8-1986, R. Robles G. 977 *XAL! [cultivated] Papantla, suelo poroso bien drenado con abundante materia orgánica asociada a Gliricidia sepium, Erythrina berteroana, Bursera simaruba, bejuco, flor verde amarillenta, nom. vul. "vainilla", "caxixanath" (Totonaco), 17-02-1985, P. Reyes, N. Carcamo \& N. Garcilazo s.n. *XAL! OAXACA: Vine $10 \mathrm{ft}$ high in woods between Los Llanos de Ozumazin and Río Chiquito, District of Choapam. Lat. $17^{\circ} 35^{\prime}$, Long. $95^{\circ} 55^{\prime}$, Alt. 700 ft., 1, May, 1939, R.E. Schultes and B.P. Reko 727 *AMES(9034)! Cultivada en los vainillales de Santiago Tlatepuzco, Mpio. Usila, ca. $500 \mathrm{~m}$ s.n.m., R. Medinilla s.n. AMO(en FAA)! Cerro Machete, Distr. Pochutla, 800 m, Feb. 1941. B.P. Reko 6279 *AMES(60425)! orquídea epífita, flor verde con la base blanquecina, acahual derivado de selva alta perennifolia, 3 $\mathrm{km}$ al $\mathrm{W}$ de La Esperanza, Mpio. Ixtlán de Juárez, Sierra Norte, R. López G. 2 AMO(16698)! same data E. Morales 1 AMO(16697)! Usila, Mpio. Usila, cultivada en los vainillales de la familia Bautista, cerca de la pista de aterrizaje, $90 \mathrm{~m}$ s.n.m. 25 abril 1992, M. Soto $6672 \&$ M. Hernández *AMO(x 2; also in spirit)! mismos datos, aparentemente un clon con olor a canela y labelo teñido de café, M. Soto $6673 \&$ M. Hernández AMO! mismos datos M. Soto 6674 \& M. Hernández AMO! Dto. Tuxtepec, Mpio. San José Independencia, Cerro Clarín, en el extremo SW de la Presa Temascal, ca. $120 \mathrm{~m}$ s.n.m., selva alta perennifolia, 1 mayo 1994. M. Soto 7630, U. Guzmán \& Carlos *AMO! Instituto Tecnológico Agropecuario, San Bartolo Tuxtepec, plantación a cargo de Jesús Pérez Meza. Abril 1996. M Soto 8040 AMO! Ejido La Gran Lucha, Mpio. Valle Nacional. Vainillal particular de Nemesio Miguel Martínez. Plantación proveniente de un sólo clon que originalmente crecía en las afueras de la comunidad. Plantación de 1 ha, 2500 plantas, de 3 años de edad. Plantación a $200 \mathrm{~m}$ s.n.m., en acahual derivado de selva alta perennifolia en ladera kárstica. 17-III1997. "Ligüey" (Chinanteco). M. Soto 8117 \& A. Cibrián *AMO! La Cueva, cerca de Cerro Verde, km 25.3 del camino Jalapa de Díaz-Usila, Oaxaca, selva perennifolia de montaña, 780 m s.n.m., muy húmeda, ca. $18^{\circ} 57^{\prime} \mathrm{N}, 94^{\circ} 44^{`} \mathrm{~W}$. Plantación de vainilla de José Roldán (aparentemente hay tres clones en la plantación). 21-IV-1997. Tal vez el mismo clon que Soto 8477. Flor muy cóncava que huele a canela. M. Soto 8483 \&
M. Hernández AMO! Mun. Santa María Jacatepec, predio El Aguila, al O de San Agustín, entrando por la Reforma, $28 \mathrm{~km}$ SO de Tuxtepec, carr. a Matías Romero. $17^{\circ} 50^{\prime} \mathrm{N}, 96^{\circ} 06^{\prime} \mathrm{W}$. Elev. $550 \mathrm{~m}$. Selva alta perennifolia. 19 Ene 1988. R. Torres 11027 \& E. Martinez AMO(sterile)! MEXU(x3; sterile)! TABASCO: cultivada en el Jardín Botánico de Puyacatengo, en Teapa, fotografía! (Alderete y Capello, 1988); [cf., sterile] Teapa, $0.34 \mathrm{~km}$ al E de la Universidad Agraria de Chapingo, $17^{\circ} 31^{\prime} 31^{\prime \prime} \mathrm{N}, 92^{\circ} 55^{\prime} 33^{\prime}$ 'W, selva alta perenifolia, 28 enero 2002, J. Calónico 21157 et al. MEXU! Poblado de Nacajuca, $20 \mathrm{~m}$ s.n.m, selva mediana perennifolia, primaria, suelo negro arcilloso con abundante materia orgánica, bejuco perenne, 3 m, escaso, nom. vul. "juju", uso comestible, 3-10-1978, $R$. Ortega, W. Márquez y B. Guerrero 858 *XAL! CHIAPAS: 17 km NO de Ocozocuautla, carretera nueva a la presa de Mal Paso, selva alta perennifolia, ca. 900-1200 m, J. Castillo 833 (specimen in cultivation)! Palenque, abril de 1892, Alt. 450 m, R.M. Comisión Geográfico-Exploradora, Sección de Historia Natural No. 7725 *AMES(21309)! $6 \mathrm{~km}$ al E de Emilio Rabasa, $1 \mathrm{~km}$ al NE de La Reyna, Ocozocuautla, $16^{\circ} 55^{\prime} \mathrm{N}, 93^{\circ} 38^{\prime} 40^{\prime \prime}, 720 \mathrm{~m}$, alrededores de una casa, huerto familiar y cultivos de maíz, S. Ochoa 3659 CHIP! [cf., fruit] Reserva Ecológica "El Ocote", Mpio. Ocozocuautla, Alt. 750 $\mathrm{m}$, selva alta perennifolia, primaria, suelo calizo, perturbada, hierba perenne, abundante, fruto vaina, trepadora, 14-021986, M. Palacios-Ríos 2823 *XAL! Alrededores de la Laguna Ocotalito, cerca de Monte Líbano, selva baja perennifolia, $950 \mathrm{~m}$ altitud, M. Soto 2836, $2840 \mathrm{AMO}$ (slides, in spirit)! Mpio. Ocosingo, Estación de Biología de Chajul, vereda que conecta la vereda a La Granja con la de la Sabana I, a unos $500 \mathrm{~m}$ del Río Lacantúm, selva perturbada con bejucos y Bactris, terrenos ondulados y arenosos pero ocasionalmente inundables, ca. $200 \mathrm{~m}$ s.n.m. $16^{\circ} 08^{\prime} \mathrm{N}$, 9053' O. 13-IV-1997. M. Soto 8355 AMO(sterile)! Estación de Biología de Chajul, montículo 1, ruinas El Zapote, ca. 1 $\mathrm{km}$ de la estación. $200 \mathrm{~m}$ s.n.m. $16^{\circ} 08^{\prime} \mathrm{N}, 90^{\circ} 53^{\prime}$. En acahual de selva alta perennifolia con caña brava, muy jóven, muy escasa. 20 junio 1996. M. Soto 7947 AMO(sterile)! Estación de Biología de Chajul, junto al Río Lacantun, acahual con caña brava, muy jóven, montículo 1, Ruinas El Zapote; aparentemente es el mismo clon que Soto 7947, sobre Cecropia obtusifolia, muy escasa, vegetativamente igual a Soto 8355 , que es otro clon. Flor más verde que las plantas cultivadas, hojas más anchas no planas y fruto corto y trígono, muy largo. Probablemente silvestre. 15 de abril de 2000, $M$. Soto 9728, S. Maldonado, L. López \& P. Schluetter *AMO(x3)! Selva del Ocote, km 44.7 de la carretera Ocozocuautla-Malpaso, cerca de la presa, manchón perturbado de selva alta perennifolia con Poulsenia armata, Ficus glabrata, Reinhardtia gracilis y Zamia splendens, muy húmeda, sobre areniscas, $275 \mathrm{~m}$ s.n.m., probablemente silvestre. 21 abril de 2000, M. Soto 9922, S. Maldonado, P. Schluetter, L. López \& M. Soto *AMO! Nahá, Mpio. de 
Ocosingo; $27 \mathrm{~km}$ al SE de Palenque por la carretera fronteriza hasta el Crucero Chancalá, después $55.6 \mathrm{~km}$ por el camino de terracería hacia Monte Líbano, 16 $56^{\circ}-17^{\circ} \mathrm{o} 1^{\prime}$ y $91^{\circ} 33^{\prime}$ 91 ${ }^{\circ} 38^{\prime} ; 900 \mathrm{~m}$ de altitud; bosque tropical perennifolio: Planta trepadora de unos $4 \mathrm{~m}$ de alto con flores amarillas. 6 mayo 1999, A. Durán Fernández 1166 MEXU! YUCATAN: [sterile] "Vainilla" Yuc., "Sisbic" Maya, Cenote de Mayana, Yucatán, 1866, A. Schott 215 F(276993)! In virgin xerophytic forest, April 1916, forests of Xbac, G.F. Gaumer \& Sons 23352 AMES(*71360, 71369)! *F(446854)! $\mathrm{MO}(948146)$ ! NY! In virgin xerophytic forests, Izamal, April 1917, G.F. Gaumer \& Sons 23909 *F(466398)! *US(1268044; sterile)! [cf., poorly preserved] "Sisbic", June 4, 1899, G.F. Gaumer $\&$ sons F! Virgin forest near Chemax, on tree trunks, 29 Sep 1935, 8756', 20³9', alt. 30 m, O. Nagel sub E. Oestlund $5050 * \operatorname{AMES}(51846$, fruit)! QUINTANA ROO: Isle of Cozumel, Cenote Cedral, on tree trunks in mixed forest of Achras zapota, 2 sep 1935, 8659', 20²1', 5-10 m, alt., $O$. Nagel sub E. Oestlund 5001*AMES(51852, fruit)! Ejido Hermenegildo Galeana, predios de Artemio y Constantino López Pascual, 18¹0'33.2'N, 89¹5'08.4"W selva alta subperennifolia alternada. 10-V-2008. M. Soto 11370, L. Ibarra \& C. López AMO! WITHOUT LOCALITY: "1815 de Mexico, Epidendrum vanilla" [Sessé and Mociño collection] Pavón G! "Mexico, Mr. Cowan G! BELIZE: Machaca, forest shade, altitude $50 \mathrm{ft}$., height $35 \mathrm{ft}$., flower cream, common, 16 May 1934, A. Schipp \&-844*AMES(40477)! TOLEDO: [cf.] "Vanilla". Vine, creamish colored flowers, scented, in broken cohune ridge, Feeders Road, 14 Miles, San Antonio-Punta Gorda Road, April 20, 1949, P.H. Gentle 6721 *F(1599303)! *LL(x2)! NY! "Vianilla" Vine, flower greenish-white, scented, in acahual, on hill slope beyond San Antonio, January 30, 1952, P. Gentle 7557 MEXU(511464)! *LL(x2)! "Vainilla", Fls. pale green, in cohune ridge, Bolo Camp, uper reach of Golden Stream, April 12, 1944, P.H. Gentle 4521 *LL! "Vianilla", vine, flowers white, scented; in cohune ridge, near Jacinto Hills. December 30, 1944, P.H. Gentle 5106 *LL(x3)! Quite common along river bank here in wet swampy places, still its difficult to secure flowering material as the squirrels get them. Flowers greenish yellow. Temash River. $100 \mathrm{ft}$ alt., $30 \mathrm{ft}$, in. diam., 13th Mar 1935, W.A. Schipp S-971*AMES(43554)! Maskal Pine Ridge road, high ridge, yellow flowers, 3 March 1934, [?C.L. Lundell \&] P.H. Gentle 1234 AMES (*41360, *41361)! GUATEMALA: BAJA VERAPAZ: Bis $6 \mathrm{~m}$ lang. Bl. dichfleischig. gellegrün. Blt. mattschwefelgelle, sehr himfalling. Früchte. Blüht sehr reich. Am Rio Polochic über Tucurú, $900 \mathrm{~m}$, Selten! 30.4.1882. F.C. Lehmann 1436 G! ALTA VERAPAZ: Flowers pale greenish; lip slightly finely fringed with slight crests down middle. Vicinity of Finca Yalpemech, near Alta Verapaz-Petén boundary line, alt. 100-120 m. March 24, 1942, J.A. Steyermark 45286*AMES(62981)! *F(1195546)! PETEN: "Vianilla", vine, flowers green; Dolores, in low forest about $2 \mathrm{~km}$. $100 \mathrm{~m}$ south of village, May 3, 1961; E. Contreras $2239 *$ LL! IZABAL: Large herbaceous vine, wet thicket, frequent, vicinity of Puerto Barrios, at sea level, June 2-6, 1922, P.C. Standley $25064 * \operatorname{AMES}(22674$, fruit)! EL SALVADOR: Finca Las Canoas, $700 \mathrm{~m}$ alt. terr., climbing trees, mostly oaks, April 11th, 1969, H.C. Clason sub F. Hamer $268 \mathrm{MO}(3092269)$ ! same data, near Ahuachapan, April 9th, 1978 H.C. Clason sub F. Hamer $776 *$ SEL(049262)! "Vainilla", San Salvador, in garden, Vanilla seems to be cultivated in Salvador only as a curiosity, 1922, S. Calderón $518 * \operatorname{AMES}(22663$, sterile) *US (1151498; sterile)! HONDURAS: MORAZAN: [cultivated] "vainilla", racemes 15-20 greenish-yellowish flowers, fragrant, vine $8 \mathrm{~m}$ long or more on Cupressus lusitanica in my yard, campus of EAP El Zamorano, alt 800 m. March 28 1990, A. Molina 34346 *MO(4248893)! ATLANTIDA: [cf.] "Vainilla". Wet forest. Large herbaceous vine climbering over trees. Fls. pale green throughout. Lancetilla Valley, near Tela, altitude 20 to $600 \mathrm{~m}$, Dec. 6. 1927, Mar. 20, 1928, P.C. Standley 55583 *AMES(36947, sterile)! F(581081)! Climbing on tree, Lancetilla Valley, $159 \mathrm{ft}$ alt., 8/12/1934, T.G. Yuncker 4993 *AMES(105299, sterile)! COMAYAGUA: [cf., fruit] "Vainilla", frutos muy aromáticos cuando secos. Planta trepadora sobre el matorral en el bosque de montañuela, alt. 1300 m, Marzo 31, 1963, A. Molina 11777A F(1620024)! NICARAGUA: ZELAYA: Logging camp near Quebrada La Talolinga. Elev. ca. 170 m. ca. $11^{\circ} 51-52^{\prime} \mathrm{N}, 84^{\circ} 26-27^{\prime} \mathrm{W}$. Tropical wet forest. Climbing vine fruit green, J.S. Miller \& J.C. Sandino 1138 MO! COSTA RICA: LIMON: "Vainilla". Large epiphytic vine; leaves thick; fruit green; Hamburg Finca, on Río Reventazón below Cairo, altitude about 55 meters. Febr. 19, 1926, P.C. Standley \& J. Valerio 48904 *AMES(32697, fruit)! *US(1309657)! in regione Atlantica: „Hamburg”, $9 \mathrm{~km}$ ab ore fluminis Reventazón, inter Musas cultas, epiph! fl. viridi-lutei, altitudo: 15 m, Die: 2.V.1930, G. Cufodonti 735 *AMES(37507)! W(1770)! Forest between Punta Manzanillo and Punta Nona, E of Manzanillo de Talamanca. Elev. ca. 8-12 m. 9 9 $38^{\prime} \mathrm{N}, 82^{\circ} 38^{\prime} \mathrm{W}$. Vine appressed-climbing in lower part, the fertile branches pendent, festooning small tree in understory of open forest atop coral bluffs along coast just E of Punta Manzanillo; borne ca. 3-4 m above ground. Flowers whitish-green, without fragrance (11:30 AM). Fruits green. Leaves thick, subsucculent. Flowers and fruits, 2 May 1985, *M.H. Grayum \& G. Schatz 5257 CR(119858)! Pococi Cantón. Refugio de Vida Silvestre Barra del Colorado, Cerro del Tortuguero, summit ridge. $10^{\circ} 35^{\prime} \mathrm{N} 83^{\circ} 32^{\prime} \mathrm{W}$, ca. $100-119 \mathrm{~m}$. Vining to ca. $3.5 \mathrm{~m}$ above ground on small tree in secondary forest. Leaves very thick and fleshy. Corolla light greenish, the labellum longitudinally pleated internally and more or less lacerate marginally. 22 January 1997, M.H. Grayum, B. Hammel, J. Schipper \& L. Merrill 11141 INB! Cantón de Talamanca, P.N. Cahuita. Faja costeña de Limón. Sendero a 
Puerto Vargas, $09^{\circ} 44^{\prime} 20^{\prime \prime} \mathrm{N}, 82^{\circ} 49^{\prime} 30^{\prime \prime} \mathrm{W}, 2$ m. Planta trepadora, creciendo a orilla de sendero. Frutos inmaduros verde -claro y maduros verde amarillento. Común. 9 December 1993, E. Lépiz 87, L. Poveda \& V.H. Ramírez INB! PUNTARENAS: Cantón de Golfito. Valle de Coto Colorado. Ribera del Río Esquinas. Boca Río Esquinas. 08 $44^{\prime} 00^{\prime} \mathrm{N}$ $83^{\circ} 20^{\prime} 00^{\prime \prime} \mathrm{W}, 30 \mathrm{~m}$. Bejuco flores blancas, frutos verdeamarillentos. 22 December 1993, M. Segura 264 \& F. Quesada INB! CARTAGO: Pejivalle, Very common in forest on ridges, seen also by riverside. No open fls found, May 1924, G.H. Lankester 847 AMES(28561)! PANAMA: PANAMA: [sterile] Gross Lathrops trail, Barro Colorado Island, June 26, 1931, L.H. Bailey \& E. Zoe Bailey 374 AMES(37507)! [sterile] Wet forest; large herbaceous vine; occasional, Barro Colorado Island in Gatún Lake, altitude 120 meters or less, Nov. 18-24, 1925, P.C. Standley 40897 *US(1251676)! Barro Colorado Island, Lutz Trail 300, vine, much scandent, seldom branching, sterile, July 10, 1970, T.B. Croat 11177 SCZ(2261)! [cf.] Wheeler Trail, Barro Colorado Island, Oct. 26 1931, O. Shattuck 230 AMES(71355, juvenile, sterile)! [cf., sterile] Wooded swamp; large herbaceous vine. Between France Field, Canal Zone, and Catival, Province of Colón, January 9, 1924, P.C. Standley 30160 US(1225400)! SAN BLAS: Flowers pale green, April 28, 1933, G. Proctor Cooper 287 AMES $(* 40380, * 71354) ! * \mathrm{~F}(771391)$ ! NY! *US(1557502)!

ReFERENCES: Hooker, Bot. Mag. 117: t. 7167. 1891; Rolfe, Journ. Linn. Soc. Bot. 32: 463. 1896; Duss, Ann. Inst. Col. Marsaelle 3: 601. 1897; Cogniaux in Urb. Symb. Antill. 6: 322. 1909; Ames \& Correll, Orchids of Guatemala, Fieldiana: Bot. 26(1): 57, fig. 16. 1952; Cabrera, T. 1999. Orquídeas de Chiapas: 39; Luer, Nat. Orch. Florida 72. 1972; Garay \& Sweet, Fl. Less. Antill. p. 44, fig. 7. 1974; Hamer, Orq. El Salvador 2: 372-373. 1974; Hallé, Fl. Nov.-Caledonie 8: 407. 1977.

13. Vanilla pompona Schiede, Linnaea 4: 573. 1829.

TYPE: "Baynilla pompona HispanoMexicanorum"; Mexico, Papantla et Colipa, Schiede 1043, "Vanilla pompona nob. interim Vaynilla pompona Papantlensis in sylvis Papantla, Ja. 29" BM (lectotype; Garay Fl. Ecuador Orch.)!; isolectotype $\mathrm{W}$ (sterile)!

Vanilla pompona is a variable, widely distributed species. We consider it rather to be a species complex.

The specific name is based in a Mexican specimen collected in central Veracruz. Mexican populations are apparently isolated from the rest of the populations of the species because there are no known populations in Chiapas, Guatemala, Belize, or El Salvador. The taxon reappears only in Central Honduras and Nicaragua. This geographical isolation is correlated and probably the reason that Mexican samples in the ITS tree form a clade with high bootstrap support. The Mexican plants also have slightly different morphology, since the flowers and leaves are smaller, and the midlobe of the lip deeply emarginate, but the general aspect of the vine and flowers is very similar to the plants from Central and South America.

Perhaps a more detailed analysis of the flower may reveal more differences, but there is a notable lack of well-preserved flowers in the $V$. pompona group.

The rest of the samples of $V$. pompona have a paraphyletic relationship with the Mexican samples, but are more or less clustered into two groups. One of the groups encompasses the samples from Honduras, Nicaragua, Costa Rica and Panama. Differently from the Mexican and the South American vines, these samples sometimes have flowering shoots with rather small leaves, that is, they keep the juvenile stem morphology. Even though they do not form a monophyletic group within the tree it seems better to consider them another group within the species.

All the South American samples have commom synapomorphic DNA characters, like peculiar nucleotide bases in certain positions and common deletions or insertions, although they also form a paraphyletic group.

We have considered recognizing these three groups in the V. pompona complex as different species, but the topology of the ITS tree, with the Mexican samples forming a monophyletic, derived group, and the other two geographic groups being rather paraphyletic, and the lack of constant, morphological traits have led us to give them subspecific ranks. Therefore, subspecies pompona, pittieri, and grandiflora are here recognized.

\section{3a. Vanilla pompona Schiede subspecies pompona}

COMMON NAMES: "vainilla platanillo", "platanillo", "vainilla pompona", "plátano", "vainilla cimarrona", "bania" (oaxaca), "nuguyu" or "nejuyu" (Oaxaca, Zoque), "vainilla", "litsmoya" (southern Veracruz; ?Popoluca); "vainilla gruesa" (Guerrero and S Oaxaca). 
Hemiepiphytic, massive vine, little branched, leafy, up to $16 \mathrm{~m}$ high. Stems terete, smooth, pale green dotted with whitish, 10-24 mm thick; internodes $11-14.5 \mathrm{~cm}$ long. Aerial, free roots thick; terrestrial roots pilose, 4 $\mathrm{mm}$ thick; attaching roots conspicuously flattened on the lower surface, whitish-greenish. Leaves subsessile; blade variously shaped, ovate, widely elliptic, oblongfalcate, base widely rounded to subcordate, apex acute to subapiculate, coriaceous, very fleshy, brittle, pale green, $22-29$ x 8-13.7 cm, $3 \mathrm{~mm}$ thick. Inflorescence 7-20-flowered raceme, up to $200 \mathrm{~mm}$ long. Bracts widely ovate, obtuse, rounded, concave to cymbiform, apex somewhat conduplicate, ca. $8 \times 10 \mathrm{~mm}$. Flowers successive, 1-2 open at once, ephemeral, tubular or with spreading segments, 58-83 (69.67 \pm 9.96$) \mathrm{mm}$ long; $7.5-10 \mathrm{~cm}$ in diameter; pale yellow, lip orange yellow, very showy; fragrance very strong, spicy, mint-like. Ovary arcuate, oval-subtrigonous in cross section, dorsiventrally flattened, arcuate, somewhat twisted, very slightly grooved on one face, smooth, green, 37-45 (42.29 \pm 2.71$) \mathrm{mm}$ long, 5-7 (5.85 \pm 0.78$) \mathrm{mm}$ wide, 3-4 (3.29 \pm 0.36$) \mathrm{mm}$ thick. Dorsal sepal long oblanceolate to spatulate, apex obtuse, rounded, subcalyptrate and minutely warty on the apex of the outer surface; base long unguiculate, long attenuate, canaliculate, the claw ca. 17-30 mm long, $8 \mathrm{~mm}$ wide in the broadest part, blade concave to somewhat conduplicate, 11$16.5(14.06 \pm 1.73) \mathrm{mm}$ wide, ca. 14 veined, smooth, thick and fleshy, total length $52-75(66.37 \pm 6.42) \mathrm{mm}$. Lateral sepals long oblanceolate, oblique, apex obtuse, rounded, subcalyptrate and minutely warty on the apex of the outer surface; base long unguiculate, long attenuate, strongly canaliculate, the claw ca. $28 \mathrm{~mm}$ long, $9 \mathrm{~mm}$ wide in the broadest part, blade concave, 13$16(14.87 \pm 1.13) \mathrm{mm}$ wide, ca. 13-veined, smooth, thick and fleshy, total length 56-75 $(68.8 \pm 6.79) \mathrm{mm}$. Petals oblanceolate-oblong, arcuate, slightly sigmoid and oblique, the upper margin more straight, apex truncaterounded, base attenuate, basally slightly canaliculate, blade flat to lightly concave, with an elevated, axial, flat keel on the lower surface, ending in a triangular, acute, flat process, $2 \mathrm{~mm}$ long; conspicuously canaliculate at the apex of the outer surface, ca. 12-veined, 59-75 $(67.83 \pm 5.58) \times 11-17(14.25 \pm 2.15) \mathrm{mm}$. Lip attached to the column along the margins of the basal half 30 $40 \mathrm{~mm}(35,40,30,37,39)$ tubular, trumped-shaped, cymbiform, deepest near the middle, axially grooved on the lower surface; when spread out $60-80(71 \pm 8.52)$ $x \quad 29-40(35.8 \pm 4.26) \mathrm{mm}$; unguiculate, the claw canaliculate, with rows of trichomes, 22-30 (24.2 \pm 2.92$)$ $x$ ca. $5 \mathrm{~mm}$ at apex, $3 \mathrm{~mm}$ at base; the blade flabellate to very obscurely trilobed, margin undulate, ca. 40 veined, apex deeply emarginate-bilobed; lateral lobes long triangular-ovate, oblique, rounded, 30-39 (35.2 \pm 3.48$)$ $x$ 10-15 (12.6 \pm 2.06$) \mathrm{mm}$; midlobe inconspicuous, the margins fairly reflexed, revolute, deeply bilobed, ca. 6-10 (8 \pm 2$) \mathrm{mm} \times 13-22(17 \pm 3.4) \mathrm{mm}$; penicillate callus at $32-46 \mathrm{~mm}$ from the lip base, made up by ca. 10-14 congested, retrorse, approximately trapezoidal, laciniate scales, the scales regularly united each to other along the lateral margins, ca. 5.5-7 $\times 5-5.5 \mathrm{~mm}$, continuous with 3 thick keels that soon become fused in a cushion like, claviform, rounded, rugose callus ending at the very apex; 18-23 $(20.6 \pm 1.85) \times 3.5-4.5 \mathrm{~mm}$. Column elongate, conspicuously sigmoid, $43-59(53 \pm 5.54) \mathrm{mm}$ long, $3.2 \mathrm{~mm}$ wide; ventral surface lanuginose on the apical half, below the stigma; apex dilated, 4.5-6.5 mm wide; vertical wings triangular-flabellate, the lower margin acute, uncinate, ca. $2 \times 4.5 \mathrm{~mm}$. Stigma trilobed, the lobes emergent, with a convex rostelum, ca. $3 \times 4.5$; lateral lobes divergent each to other. Fruit variable, usually arcuate, trigonous, thick, green, blackish when rippen and strongly aromatic, 7.3-15 cm long, ca. 14 mm thick $(n=6)$. Fig. 13.

Distribution: Mexico (Nayarit, Jalisco, Colima, Michoacán, Guerrero, Oaxaca, Veracruz). Specimens cited as V. pompona from Guatemala and Belize, and most from Honduras have turned out to be other taxa.

Vanilla pompona has a disjunct distribution. The type came from Veracruz, Mexico and this group of populations extends into N Oaxaca until the Tehuantepec Istmus, but not reaching Chiapas. Subspecies pompona occurs in W Mexico (Nayarit to S Oaxaca), where characteristically small flowers whose segments do not spread widely are very common.

In the ITS tree all the samples of $V$. pompona from Mexico (both from the Atlantic and Pacific watershed) form a nested subclade with high bootstrap support (97\%). Another clade within V. pompona includes material cultivated in Guadaloupe, and from Suriname and Guyanas, whose bootstrap value is moderate (70\%). The rest of the samples of the complex have unresolved relationships at the base of the $V$. pompona clade, which has a $100 \%$ bootstrap value and is sister to $V$. 

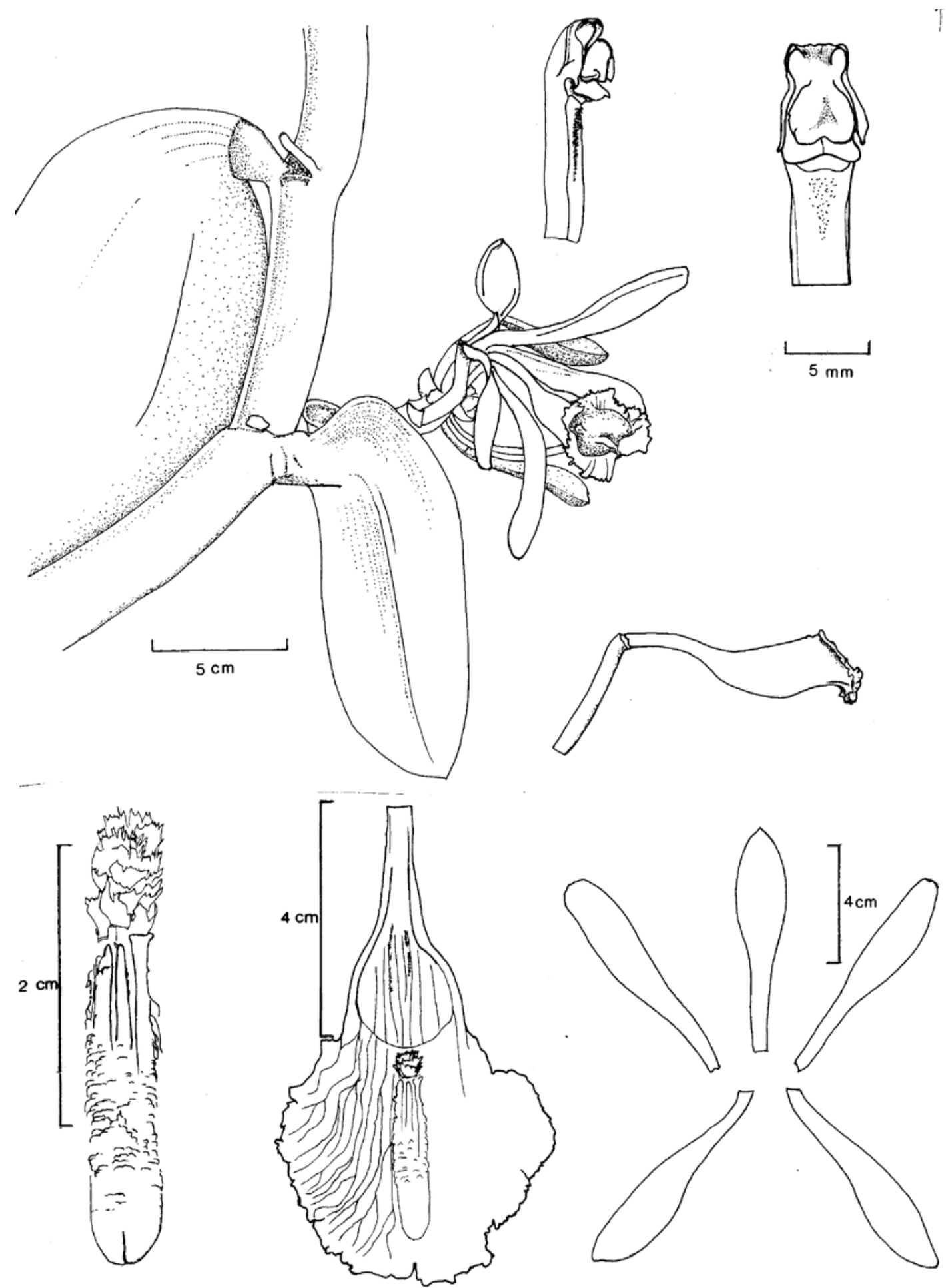

FIGURE 13. Vanilla pompona Schiede subsp. pompona. Based on M. Soto 7746. Drawing by M. Soto. 
calyculata, a clearly different species.

The distributiona, molecular, and morphological data suggest that subsp. pompona may be the result of a relatively recent colonization of Mexico through a rather long-dispersal event from Central American plants. We believe that we can recognize at least two taxa in the complex: V. pompona subsp pompona and $V$. pompona subsp. grandiflora (Lindl). Soto Arenas.

Ecology: from sea level up to $1200 \mathrm{~m}$, more common at $300-900 \mathrm{~m}$; in several types of tropical forest (deciduous, subdeciduous, evergreen, lower mountain, gallery forests, in savannas or warm pine-oak forest, also in flooded areas) common in seasonally very dry areas; this species is usually absent from the wet forests, but occasionally can be located there in limestone outcrops. Flowering period from April to early June.

Vanilla pompona was described from sterile specimens collected by Schiede near Papantla and Colipa, in northern Veracruz, about 1829. The big plants, with very fleshy and thick stems bear huge, fleshy leaves, very variable in form, but always big in flowering shoots of Mexican plants. The large, deep yellow, and strongly fragrant flowers are very showy when they spread their segments (rarely in western Mexican populations); the short, thick fruit is strongly aromatic and very much appreciated by peasants, and also by vanilla conoisseurs. The odor of the cured fruits is typically heliotropin-like (Ehlers and Pfister, 1997). It is cultivated in small scale in the V. planifolia plantations, as a curiosity or charm, rarely offered to the commerce. On the Pacific slope, where it is known as "vanilla gruesa", is very common in the coffee plantations, protected, but used only for local consumption.

Vanilla pompona subsp. pompona is somewhat variable; the specimens from the Pacific slope usually have bigger leaves and thicker stems, smaller flowers, and the perianth segments apparently never spreading; vegetative features probablly represent a plastic response to drier conditions, and the flower size of some specimens of southern Oaxaca approach those of the Gulf watershed; the smallest-flowered specimens are found in Nayarit and Jalisco.

OTHER RECORDS: MEXICO: NAYARIT: Camino de Ruiz a Jesús María, ca. $200 \mathrm{~m}$ altitud, cafetal derivado de selva mediana subdecidua, abril 1986, G. Salazar \& M. Soto 2009, 2010, 2011, 2013, 2017 AMO! El Caimán, 100 m sobre la brecha hacia El Naranjo, que sale del km 10 del camino El Cuarenteño - El Cora, encinares calientes mezclados con selva mediana subcaducifolia en las cañadas, Quercus cf. conspersa, Byrsonima crassifolia, Bursera acuminata, 490 m s.n.m., $21^{\circ} 26^{\prime} 22.2^{\prime \prime}$ y $105^{\circ} 06^{\prime} 09.6^{\prime \prime}$. Nos guió el Sr. Benito Decena Jiménez, de El Cora. 26/ junio/1998. M. Soto 8613 y E. Huerta AMO! M. Soto 8617 y E. Huerta AMO(x4)! JALISCO: La Playa (oeste de Los Llanitos), Mpio de Puerto Vallarta, bosque subdeciduo, trepadora, $550 \mathrm{~m}$ alt., flores amarillas, muy escasa, $R$. González Tamayo 884 *AMO! *LL! Mpio. Puerto Vallarta, entre Los Llanitos y Los Almacenes, González Tamayo s.n. dibujo! Mpio. Cabo Corrientes. above El Tuito, road to Mina de Cuale, R. McVaugh 26397 MICHOACAN: Mpio. Aquila, San Pedro, Coalcomán, 550 m, 6-19-39, "Vanilla", forest, vine, G.B. Hinton 13815 *AMES(57796)! NY! *US(1805771)! Aquila, Tizupan, Coalcomán, 4-8-41, "Vanilla", forest, G.B. Hinton 15910 *AMES(60655)! NY! GUERRERO: Vallecitos, Montes de Oca, 9-13-1937, "vanilla", on a tree, G.B. Hinton et al. $11387 \mathrm{~K}$ ! *US(2020421)! Sierra Madre, Guerrero- Michoacán, 400$1000 \mathrm{~m}$ alt., Mars 1900, Pl. grimpante \& áttachant aux troncs d'arbres- Recólte des fruites d'Octobre à Novembre. Endroits ombragés,"Vainilla", E. Langlassé 941 *AMES(71358)! G(x2)! K! *US(386288)!. OAXACA (specimens from the Pacific slope): Pacific slopes of Sierra Madre, near Copalita and below Pluma Hidalgo, climbing on tree trunks, 26 Jul 1936, 500-1000 m, O. Nagel \& J. González sub E. Oestlund 6102 *AMES(51840)! km 190 Oaxaca-Pto. Angel. 14 mayo 1990. Flor prensada de material en líquido $O$. Suárez $1153 \mathrm{AMO}(15906$; also in spirit)! Sanguijuela, Mpio. Juquila, 1200 m s.n.m., 21 sept. 1992, V. Meza \& M. Tovar s.n. AMO(only fruit)! ca. San Gabriel Mixtepec, selva mediana subcaducifola en cañadas con encinar seco en las lomas. ca. 600 m s.n.m. 17 de abril de 1992. M. Soto 6607, N. Pérez y E. Martínez AMO! Cerca de San Gabriel Mixtepec, cafetal en la zona de selva mediana subcaducifolia y encinar caliente, $800 \mathrm{~m}$ s.n.m. 11 mayo 1994. Fotografiada, flores semicerradas. M. Soto 7632, A. Ryan, E. Sandoval A. Rojas \& A. Martínez *AMO! OAXACA (specimens from the Gulf slope): Consoquilla, /42, Liebmann 288 W(11761, drawing)! 1859, Cuming s.n. G! Near Mogoñé, climbing on trees, Isthmus of Tehuantepec, fruit very fragrant, $95^{\circ} 01^{\prime} 17^{\circ} 0$ ', $100 \mathrm{~m}, 18 \mathrm{Feb} 1935, O$. Nagel sub E. Oestlund 4574 *AMES(51841)! F(1257235)! *MO(1145434)! Isthmus of Tehuantepec. Near Mogoñé, climbing on trees, $95^{\circ} 01^{\prime} 17^{\circ} 0^{\prime}, 100 \mathrm{~m}, 20 \mathrm{Apr} 1935, \mathrm{H}$. Knape sub Oestlund 4781 *AMES(51842)! F(1257236)! *MO(1145435)! *SEL(011366)! *US(1809788)! San Juan Guichicovi, "vainilla", hierba, pachine seco, en la orilla del camino, uso, con la fruta machacada, VIII-1986, Nereyda Antonio \& M. Heinrich UI 188 MEXU(431242)!! Mpio. Sta. María Chimalapa: Arroyo Huahuagtzá, ca. $5.5 \mathrm{~km}$ al E LANKESTERIANA 9(3), January 2010. (C) Universidad de Costa Rica, 2010. 
de Sta. María; lat. $16^{\circ} 55^{\prime}$ N, Long. $94^{\circ} 39^{\prime}$ O, alt. $250 \mathrm{~m}$; acahual en área plana en orilla de arroyo (anteriormente selva); suelo negro. Bejuco; fruto verde, carne amarillaverdosa con semillas negras; común; n.v. "bainia", "nuguyu" (en zoque); se usa en forma de aceite para el cabello para que de más olor, 5 septiembre 1984, H. Hernández G. 396 *AMO(8094, fruit)! CHAPA! Mpio. Sta. Ma. Chimalapa: Arroyo Rancho Viejo, ca. 2-4 km al E de Sta. María; lat $16^{\circ} 54^{\prime} \mathrm{N}$, long. $94^{\circ} 39^{\prime} 30^{\prime \prime} \mathrm{O}$; alt. $230 \mathrm{~m}$; cañada con selva (rodeada por encinar) con Poulsenia, Ficus, Brosimum etc., suelos color café cascajoso. Epífita; fl. amarilla; "vainillo" (en castellano), "nejuyu" (zoque); frecuente; se usa para darle fragancia al cabello (se seca primero), 6 abril 1987, $H$. Hernández 2418, AMO(16964)! $4 \mathrm{~km}$ al W de la frontera Oaxaca-Chiapas, carretera a Tapanatepec, Dto. Juchitán, epífita, flor amarilla, poco frecuente, veg. riparia, suelo rocoso, 27 Marzo 1984 [botones], $R$. Torres 4807 \& $C$. Martínez MEXU! NY! Mpio. Santa María Guienagati, Loc. Dto. Tehuantepec. $3 \mathrm{~km}$ al $\mathrm{N}$ de Santa María Guienagati, carretera a Guevea de Humboldt. $16^{\circ} 43^{\prime} \mathrm{N}, 95^{\circ} 22^{\prime} \mathrm{W}$; elev. $460 \mathrm{~m}$, riparia con cafetal. Epífita, fruto verde, poco frecuente, 27 junio 1991, A. Campos 3721 MEXU(578082)! ca. Valle Nacional, 1996, J. Pérez Mesa s.n. AMO(in spirit)! Terrenos comunales de San Agustín, Mpio. Sta. Ma. Jacatepec; a unos $2 \mathrm{~km}$ al W de San Agustín, selva húmeda con Manilkara, Brosimum, Pseudolmedia, con cafetal, a 350 $\mathrm{m}$ s.n.m. Planta silvestre de ca. $18 \mathrm{~m}$ de alto, protegida, con flores. 22-IV-1997. M. Soto 8495, M. Hernández, F. Sánchez y M. Tensohua AMO! VERACRUZ: Near Zacuapan. On trees, 12 feb 1932, $96^{\circ} 52^{\prime}$ and $19^{\circ} 12^{\prime}$ 'ca. $900 \mathrm{~m}$, O. Nagel sub E. Oestlund 2684*AMES(41477, sterile)! From Mexico. Secured by Prof. P.H. Rolfs, in charge of the Subtropical Laboratory, Miami, Fla., while traveling in Mexico as agricultural explorer of the Office of S\&PI in April, May, and June, 1905. This species is a very stronggrowing vanilla. Produces the largest fruits and in considerably quantity. Secured near Papantla, Person interested: David Fairchild. P.I. No. 14440 SEL(011358; photo)! Valle de Córdoba, 20 april 1865-6, Bourgeau 2332 $\mathrm{K}$ ! Region of Zacuapan, in brush wood, half shady, ca. 800 $\mathrm{m}$, Jun 1935, C.A. Purpus sub E. Oestlund 4852 *AMES(51839)! H. de la Higuera, 510 m s.n.m., vegetación riparia, bejuco perenne, abundancia regular, fruto aplanado [sic], septiembre 8, 1966, M. Sousa $2721 * \mathrm{AMO}(3443$, fruit)! MEXU(2774455, 296430, 277427; x3)! MO(4273614)! Cañada del Río Guazuntlán, $380 \mathrm{~m}$ s.n.m., selva alta perennifolia primaria, perenne, "litsmoya", colectada en fruto. Usos: seca se pone en vaselina y se unta en el pelo, septiembre 30, 1967, M. Sousa 3276 *AMO(8592, fruit)! MEXU(fruit, 284554)! a $1 \mathrm{~km}$ al NE de Soteapan, $400 \mathrm{~m}$ s.n.m., encinar, epífita, escasa, perenne, 30 Sept. 1967 [estéril], M. Sousa 3272 MEXU(284553)! "vainilla", La Ceiba, Municipio de Puente Nacional, bosque de árboles varios en cañada, $100 \mathrm{~m}$ altitud, $F$. Ventura 12355 *AMO(785, fruit)! MEXU(fruit, 235724)! Barranca de Monterrey, entre el manantial y la cueva del abono, Mpio. Axocuapan, alt. 380 m s.n.m., selva mediana subperennifolia, bejuco, fruto verde, nom. vul. "vainilla cimarrona", trepador, 02-01-1987, M. Cházaro, L. Robles \& J. Márquez 4376 *AMO(9026, fruit)! XAL(fruit)! El Remudadero, por la carretera Conejos-Totutla, Mpio. Paso de Ovejas, $\left(19^{\circ} 17^{\prime} \mathrm{N}\right.$, $96^{\circ} 33^{\prime} \mathrm{W}$ ), selva mediana subcaducifolia primaria, suelo arcilloso, pedregoso, en la barranca, bejuco perenne, $10 \mathrm{~m}$, escasa, fruto verde, nom. vulgar "platanillo", fruto comestible, bejuco trepador, 01-11-1982, G. Castillo C. $2747 *$ XAL(fruit)! Miraflores, $9 \mathrm{~km}$ al NW de Atoyac, Mpio. de Atoyac, $18^{\circ} 57^{\prime} \mathrm{N}, 96^{\circ} 49^{\prime} \mathrm{W}$, alt. $900 \mathrm{~m}$ s.n.m., selva mediana subperennifolia, primaria, suelo cárstico, bejuco perenne, $8 \mathrm{~m}$, flor amarilla, nom. vulgar "vainilla", 18-05-1985, R. Acevedo \& R. Acosta 195 *XAL! [cf., fruit] Límites de Veracruz con Tabasco, Mpio. Coatzacoalcos, $18^{\circ} 03^{\prime} \mathrm{N}, 96^{\circ} 06^{\prime} \mathrm{W}$, selva baja inundable, primaria, suelo negro pantanoso, hierba trepadora, perenne, $6 \mathrm{~m}$, fruto verde en vainas, nom. vulgar "vainilla", 18-05-1980, J.I. Calzada $6096 \mathrm{~F}(1975502)$ ! *XAL(fruit)! Alrededores de San Fernando, Mpio. Soteapan, $18^{\circ} 18^{\prime} \mathrm{N}, 94^{\circ} 53^{\prime} \mathrm{W}$, alt. $720 \mathrm{~m}$ s.n.m., pinar-encinar, primaria, suelo rojo arcilloso, bejuco perenne, $1 \mathrm{~m}$, escaso, fruto verde, 18-12-1978, $R$. Ortega et al. $1021 \mathrm{~F}(1963648$, flower)! *XAL(fruit)! $1 \mathrm{~km}$ al S de Palmillas, Mpio. Puente Nacional, $19^{\circ} 13^{\prime}$ N, 96 $46^{\circ}$ 'W, 600 m s.n.m., selva baja caducifolia, primaria, suelo delgado, arcilloso, pedregoso, café, con poca materia orgánica, bejuco perenne, $4 \mathrm{~m}$, fruto verde, 13-03-1985, G. Castillo \& M.E. Medina 4284 *XAL(fruit)! El Pochote, Mpio. Zentla, hierba, floración en mayo, $N$. Deméneghi G. 558 *XAL(fruit)! Mecayapan, región de Los Tuxtlas; acahual derivado de encinar-pinar, 13/01/1998, S. Cruz Ramirez sub M. Soto 8777 (cultivated plant)! Miraflores, cerca de Atoyac, ca.750 m s.n.m. Acahual de selva mediana perennifolia submontana muy húmeda. Protegida o cultivada. Planta muy vigorosa, tallos $13-26 \mathrm{~mm}$ de diámetro, hojas hasta de $30 \times 12.5 \mathrm{~cm}$, flores de $9 \mathrm{~cm}$ de largo, no abiertas, sépalos y pétalos verdes exteriormente, parte interna amarillo-verde limón, labelo amarillo yema cocida con algunas líneas ocre, garganta profunda con la parte apical amaillo-naranja, aroma especioso, hierbabuena y algo más. 29-IV-1995. M. Soto 7746 \& J. Arguijo *AMO! El Angostillo, 34 km de Huatusco, ca. 14 km de Manuel González, Congregación El Pochote, La Reforma, Mpio.de Zentla, 500 m s.n.m.; selva baja caducifolia en barrancas basálticas; aroma fuerte a mentol, visitada por Eulaema en la casa de Julio Arguijo. 30-IV-1995. M. Soto 7747, M.A. Flores, J. Arguijo, D. Deméneghi, M. Deméneghi *AMO(x2)!

REFERENCES: McVaugh, Fl. Novo-Galiciana. 16: Orchidaceae: 351-353, fig. 115, 1985.

13b. Vanilla pompona Schiede subsp. grandiflora 
(Lindl.) Soto Arenas, comb. et stat. nov.

BASIONYM: Vanilla grandiflora Lindl.,Gen. Sp. Orchid. Pl. 435. (1840).

TYPE: Guyana Francesa, Martin s.n. (holotype, K-L!).

Illustr. Dunsterville y Garay Venez. Orchid. Ill. 1: 435 (1050, as V. pompona). N.v.: Palanda vainilla, Ecuador: vainillón.

Vanilla claviculata Duss non Sw.; V. lutescens Moq. ex Dupuis

COMmon Names: "vainillón" (French and British Antilles),

Distribution: Apparently naturalized in the West Indies.

There is no adequate material from NW South America, but the specimens from the Amazon basin, Guyanas, Coastal Venezuela, and S Brazil are considered here to belong to $V$. grandiflora. It is unknown if the plants from $\mathrm{W}$ Ecuador are $V$. pompona or $V$. grandifolia.

ECology: Lubinsky, Van Dam \& Van Dam (2006) report the pollination of $V$. (pompona subsp.) grandiflora by male Eulaema meriana, one of the largest of the euglossine bees. They also photographed a male Eulaema cingulata gathering scents from the mature fruit of this species. There has been at least one other report of euglossine bees brushing on Vanilla fruits (Madison, 1981). It is quite possible that the Euglossini may play a role in the dispersal of Vanilla seeds, as well as the pollination of the flowers.

Vanilla pompona is very similar to $V$. grandiflora Lindl. ("French Guiana: without precise locality, Martin s.n., K-L!), and the latter is has been recognized as a synonym by most orchid taxonomists. However, $V$. grandiflora is different because it has a rather oblong lip blade, not flabelate to obscurely trilobed as in $V$. pompona. In $V$. grandiflora the flowers are larger, with the lip $>80 \mathrm{~mm}$ long, the callus $9-10 \mathrm{~mm}$ long and originated at ca. $60 \mathrm{~cm}$ from the base and the column is $60-75 \mathrm{~mm}$ long; also the apical thickening is less conspicuous in $V$. grandiflora and the flowers have usually spreading segments, while $V$. pompona is usually closed, although occasionally, specimens with spreading segments on sunny days are found, as the illustrated in fig. 13.
Vanilla lutescens Moq.-Tand. described from material of Paraguay [M. Coudert, cultivated at the Faculté de Médecine de Paris, the type, not seen; probable duplicate at $\mathrm{W}(35455)$ !] is also similar to $V$. grandiflora and maybe conspecific with it.

References: Chiron, G.R. \& R. Bellone. 2005. Les orchidées de Guyane Française: 138, photo p. 93.

13c. Vanilla pompona Schiede subspecies pittieri (Schltr.) Dressler, comb. et stat nov.

BASIONYM: Vanilla pittieri Schltr., Fedde Rep. 3: 106. 1906.

TYPE: Costa Rica: In der Wäldern an Ufern des Río Ceibo bei Buenos Aires, c. 200 m. M-H. Pittier no. 6600, blühend im Januar 1890, $\mathrm{B}$ (destroyed); AMES(24329; drawing of the holotype)! BR!

Distribution: Honduras, Nicaragua, W Costa Rica and the Pacific side of Panama.

The available Costa Rican material is not very well-preserved, but seems to be more similar to the Mexican populations of the Pacific slope; the name V. pittieri Schltr. is available to these Costa Rican populations. The type of $V$. pittieri was lost in Berlin bombing; a sketch of the type made under R. Schlechter's supervision, and a rather crude illustration of the flower is kept at AMES; the lip is shown as entire, with a very elliptic blade, as it had been prepared from an immature bud. There are additional specimens from the area of Buenos Aires, Puntarenas, that match our concept of $V$. pompona.

OTHER RECORDS: NICARAGUA: CHONTALES: ca. $2.8 \mathrm{~km}$ above ( $\mathrm{N}$ of) Cuapa; ca. $12^{\circ} 17^{\prime} \mathrm{N}, 85^{\circ} 23^{\prime} \mathrm{W}$, elev. $400-500$ $\mathrm{m}$; roadside, pastures, disturbed evergreen forest on hillside, and bank of small stream. One seen, climbing up trunk of large tree in disturbed forst near road, section of lower stem collected, W.D. Stevens, B.A. Krukoff $3690 * \mathrm{SEL}(049330$; sterile)! SEGOVIA: Oersted W(19359)! Plant - Large thick (up to $2 \mathrm{~cm}$ ) climbing leafy stems. Flowers- Large light yellow sepals and petals, yellow-orange lip. Light yellow column, orange on anterior face [mounted with description, notes an analytical drawing] A.H. Heller s.n. *SEL(003850)! NUEVA SEGOVIA: Quilalí, ca. $13^{\circ} 34$ ? $\mathrm{N}, 86^{\circ} 01^{\prime} \mathrm{W}$, elev. $430 \mathrm{~m}$, cultivated, said to have been collected wild in the vicinity about 10 years earlier; flowers yellow-green, fragrant, heavely visited by euglossine bees, fruits fleshy, dark brown, aromatic, 16 March 1980, W.D. Stevens, B.A. Krukoff 16829 
*SEL(049331)! ZELAYA: Cerro Livico, 7 km northeast of Siuna, forest slope; elev. $500 \mathrm{~m}$. Climbing trunk of tree 28 April 1978, D. Neill 3670 *SEL(047695; sterile)! COSTA RICA: GUANACASTE: Flores amarillas. Enredadera subiendo tronco de árbol, en chaparral o bosque poco denso dentro de sabana cerrada. A 5 millas al sur de La Cruz, Liberia. Alt. 200 m, febrero 11, 1963, A. Jiménez M. $313 * \mathrm{~F}(1606969)$ ! 550 $\mathrm{m}$, Calvo 1136 F(1456238)! Parque Nacional Guanacaste, Estación Maritza, sendero a la cima del Volcán Orosí. Bosque primario y secundario, $10^{\circ} 57.6^{\prime} \mathrm{N}, 85^{\circ} 29.6^{\prime} \mathrm{W}, 600 \mathrm{~m}$. Planta epífita, creciendo sobre un árbol a $5 \mathrm{~m}$ de altura y a la orilla de una quebrada. Frutos verdes. 2 julio 1989, INBio 132 INB! *CR(fruit)! PUNTARENAS: Cantón de Buenos Aires. Along the Río Ceibo, Ujarrás. 09 $14^{\prime} 00^{\prime \prime} \mathrm{N}, 83^{\circ} 18^{\prime} 00^{\prime} \mathrm{W}$, $500 \mathrm{~m}$. Thick stemmed vine; climbing high on trunk of tree in riparian forest. Lvs. succulent, deflexed. Just one young bud and one old, dry flower seen. 9 March 1993. M. Grayum 10237 INB! Esparza Macacona, margen derecha, quebrada La Turbina. Bejuco trepador, botones florales verde tenue, flor de corola amarilla, aromática, 15 enero 1987, G. Herrera \& E. Herrera $466 \mathrm{MO}(3594340)$ !WITHOUT PRECISE LOCALITY: "Vanilla reichenbachii”, Endres 270 W(16231, 16175, 16176)! Sepals and petals greenish yellow. Lip orange yellow. Pie del Turrubares, $150 \mathrm{~m}$, March 6, 1926 A. Alfaro $269 * \operatorname{AMES}(31487, * 31487)$ ! In forest between Colonia \& Las Huacas, May 25 1903, O.F. Cook \& C.B. Doyle 742 *US(474659)! "Costa Rica”, dried leaf from M. Godefroy-L., Paris, 1895 K! PANAMA: PANAMA: Low places contiguous to City, Alt Sea level. Grows in damp places. Climbs trees up to 40-60. Flowers yellow, with orange throat. Flowers FebMarch. 1919, C.W. Powell 137 AMES(*23763; AMES 28290 is $V$. phaeantha)! Moist woods; large herbaceous vine, Río Paraíso, above East Paraíso, January 7, 1924, P.C. Standley $29919 * \operatorname{AMES}(31437$, sterile)! *US(1225393)! Vine on west shore, Barro Colorado Island, March 11, 1931, C.L. Wilson $119 * \mathrm{~F}(636191)$ ! Barro Colorado Island, shores of Gatum Lake, South of Lab., Aug 28th 1929, W.N. Bangham 458 *AMES(71357, fruit)! Near Canal Zone, C.V. Piper s.n. *AMES(36948)! Low thick scrub along R. Tecumen, north of Chepo road, up to $30 \mathrm{~m}$. March 10, 1935, A.A. Hunter and P.H. Allen $852 * \mathrm{AMES}(42162)$ ! *F(1329667)! *US(1976167)! Coastal thicket; large herbaceous vine; common, Punta Paitilla, January 12, 1924, P.C. Standley 30788 *US(1229496)! Parque Nacional Altos de Campana. Epífita con botones florales verdes. Fuera del parque, a $1 \mathrm{~km}$ de la oficina del parque. Sendero de interpretación, $1 \mathrm{~km}$ al este del campamento de los guardabosques de INRENARE. Bosque húmedo tropical premontano. Elevación entre 800 y 900 m. $8^{\circ} 40^{\prime}$ N; $79^{\circ} 55^{\prime}$ 'W. 23 de abril de 1993, M.D. Correa, E. Montenegro \& E. Hidalgo 9460 PMA! Cerca de Cerro Azul, $14.8 \mathrm{~km}$ al $\mathrm{N}$ de la carretera Cd. de Panamá-Tocumen, camino Cerro Azul-Cerro Jefe, vegetación secundaria con Terminalia y Byrsonima, ca. 600 m s.n.m., trepadora, estéril, toda la población con hojas elípticas, grandes y tallos gruesos, 4 junio 2001, M. Soto 9921, G. Salazar, J. Linares y R. Gregg PMA! in cult., at Smithsonian Tropical Research Institute in Balboa. Voucher: fragrance collection. 18 Mar 1979, J.D. Ackerman 1354 SEL(039338)! In Powell's garden; large vine, Balboa, Non., 1923-Jan., 1924, P.C. Standley 28570 *US(1225365; sterile)! COCLE: ca. 5 km al N de El Copé, entrada del Parque Nacional Omar Torrijos, vegetación secundaria abierta, derivada de bosque húmedo tropical premontano con Vochysia, ca. 700 m s.n.m. 2 junio 2001, G. Salazar J. Linares, M. Soto y R. Gregg PMA!

References: Hamer, Orch. Nicaragua, Ic. Pl. Trop. pl. 1195. 1984.

\section{Vanilla sarapiquensis Soto Arenas, sp. nov.}

TYPE: COSTA RICA: HEREDIA: Sarapiquí. Llanura de San Carlos. Sardinal. Bosques residuales y tacotales camino a Finca Dos Loas. $10^{\circ} 31^{\prime} 45^{\prime \prime} \mathrm{N}$, $84^{\circ} 05^{\prime} 32^{\prime},, 70 \mathrm{~m}$. Bejuco herbáceo. Sépalos verde crema, labelo blanco, columna con la punta negra, 10 May 1995, holo. J.F. Morales 4082, E. Lépiz, V.H. Ramírez \& A. Rojas INB! iso. apparently at MO.

Vanillae costaricense aemulens differt inflorescentiis bracteisque minoribus, floribus longioribus, labello suborbiculari, 3-lobato, callo duobus carinis incrassatis prominentibus in apicem confluentibus.

Hemiepiphytic vine, leafy. Stems $4 \mathrm{~mm}$ thick; internodes $6.5-7.8 \mathrm{~cm}$ long. Aerial roots flattened, ca. $2 \mathrm{~mm}$ wide. Leaves obscurely petiolate, the petiole canaliculate, ca. $7 \mathrm{~mm}$ long, $3.5 \mathrm{~mm}$ wide; blade elliptic, long acuminate, somewhat cuneate at base, membranaceous-chartaceous in dried condition, 15.9-19.5 x 4.8-7 cm. Inflorescence very different from the vegetative shoots, a 4-flowered raceme 5.5 $\mathrm{cm}$ long, internodes up to $1.5 \mathrm{~cm}$ long; peduncle ca. $26 \mathrm{~mm}$, rachis ca. $2 \mathrm{~mm}$ thick. Bracts scale-like, ovate to lanceolate, acuminate, concave, $9 \times 4 \mathrm{~mm}$. Flowers successive, with rather spreading segments, showy, ca. $7 \mathrm{~cm}$ in diameter; tepals green-cream colored, lip white; of heavy substance. Ovary rather sigmoid, terete, somewhat thickened at base, smooth, inconspicuously sulcate, $42-53 \mathrm{~mm}$ long, 3-4 mm thick. Dorsal sepal rather spreading, convex, the margins reflexed, the apex slightly incurved, slightly undulate; elliptic, apex acute-subacute, extreme apex 

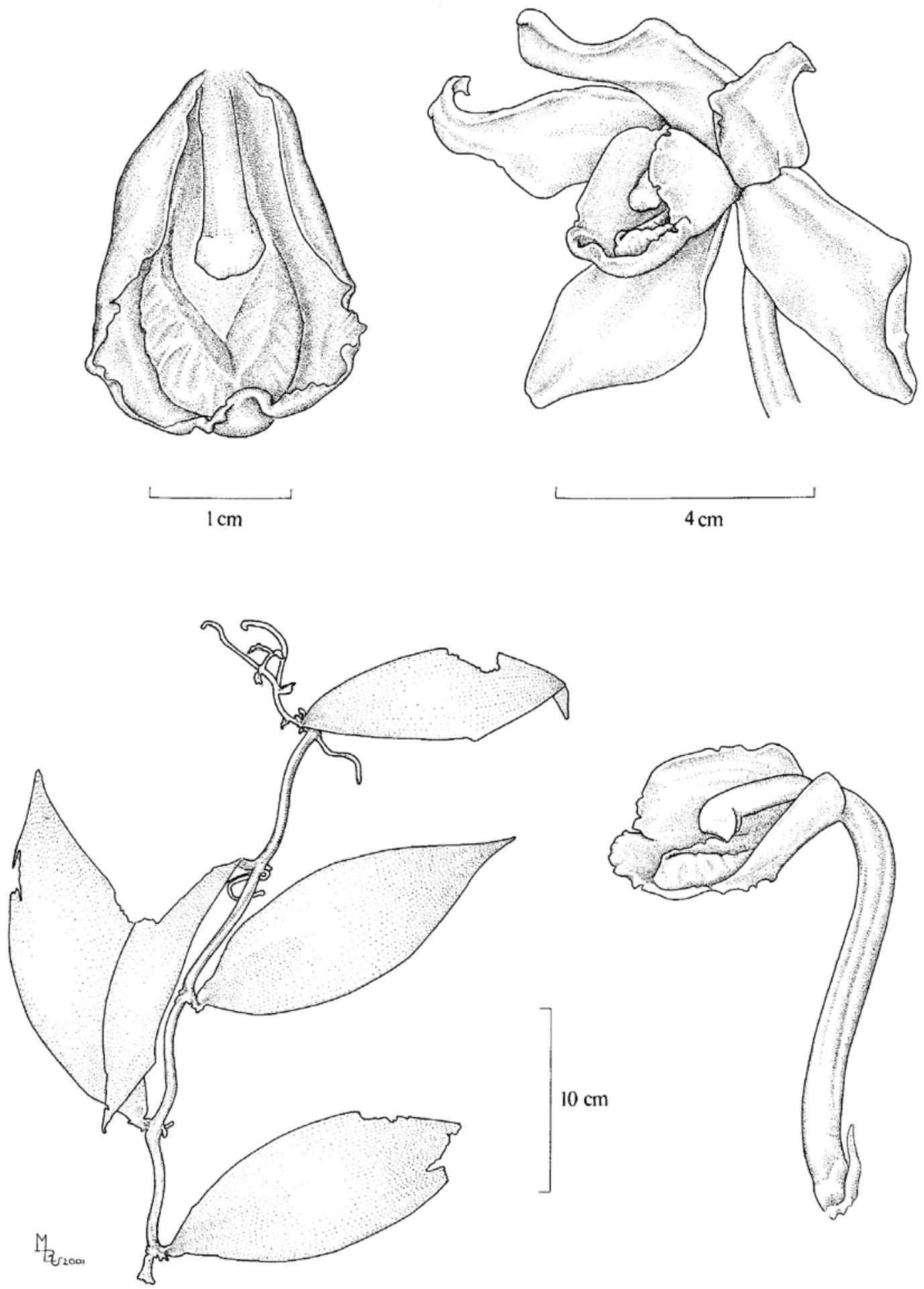

FigURE 14. Vanilla sarapiquensis Soto Arenas, based on the type specimen, J.F. Morales 4082, Drawing by M. López. 
conduplicate-subcalyptrate, rounded; base obtuserounded, ca. 10 veined, sparsely warty on the dorsal surface, $44 \times 17 \mathrm{~mm}$. Lateral sepals basally concave, convex at apex, the margins near the middle reflexed, the apex recurved, widely elliptic, obtuse, base obtuserounded, margins scarcely undulate, sparsely warty on the dorsal surface, 11-veined, $41 \times 20 \mathrm{~mm}$. Petals spreading, recurved at apex, slightly undulate on the upper margin, oblong-elliptic, oblique, subacute, base obtuse-rounded, 8-veined, smooth but axially sulcate on dorsal surface, $45 \times 16 \mathrm{~mm}$. Lip attached to the column $3 \mathrm{~mm}$, ovate-suborbicular, obscurely trilobed in outline, constricted at $2 / 3 ; 32 \times 28 \mathrm{~mm}$, the base subcordate, slightly concave, with the lateral margins erect forming a throat around the column; midlobe concave, margins inflexed, incurved at apex, rounded, $8 \times 16 \mathrm{~mm}$; the lateral lobes semielliptic, the margins minutely pleated, $21 \times 10 \mathrm{~mm}$; callus arising above the middle, builted up by a pair of broad, elevated apically confluent keels, the keels somewhat sulcate from the botton to the crest, more elevated at distal part, widely triangular in cross-section on their distal part, $18 \mathrm{~mm}$ long, $5 \mathrm{~mm}$ wide. Column arcuate, semiterete, with a dilated apex, smooth, $21 \times 4 \mathrm{~mm}$. Anther protruding, semierect the distal part perpendicular to the column body; the anther separated from the surface of the lip. Fig. 14.

DistribUtion: Known only from northern Costa Rica, in the Llanura de San Carlos; it is to be expected from adjacent Nicaragua.

ECOLOGY: Apparently in rainforest, at $70 \mathrm{~m}$ elevation. It was collected with flowers in May.

This species of the membranaceous group is known from a single collection from N Costa Rica. Vanilla costaricensis, is known from the same geographic area (Llanura de San Carlos), but $V$. sarapiquensis is distinct in its much shorter inflorescences with scalelike bracts $(V$. costaricensis has big bracts like those of $V$. inodora), larger flowers with much broader tepals, suborbicular, trilobed lip, and especially by the very different callus made up of two elevated, thick, sulcate keels, confluent in the apical part. In $V$. costaricensis the lip is subentire, ovate-flabellate, with the apex truncate or somewhat trilobed, but the lateral lobes at the apex are subequal or slightly longer than the mid lobe. In V. costaricensis the callus is made up of a pair of flat, broad keels along the axial line, from the base to the begining of the apical third, then separated in 3 low, erect, congested keels ending at the apex.

Vanilla mexicana has a distinctly trilobed lip, with the midlobe more protruding, 3-keeled, with the keels parallel. Also related is $V$. martinezii with much larger flowers, straight sepals, more rugose, basal keels, although the short inflorescence, with reduced bracts is similar.

15. Vanilla trigonocarpa Hoehne, Arq. Bot. Estado Sao Paulo, nov. ser. 1(6): 126, t. 139. 1944.

TYPE: BRAZIL:PARA: Matas de terra firme, Belém do Pará, flores em 23-11-1926 e frutos em 7-10-1926, A. Ducke s.n.. holo., HEPF(19445)!

Vanilla pauciflora Dressler, Orquideología 13(3): 229-232. pl. 1979.

TYPE: PANAMA: Prov. Panamá, carretera El Llano-Cartí, 10-15 km al norte de El Llano; 3 marzo 1976; sépalos verde pálido, pétalos crema verdoso, labelo blanco, lámina caféamarillo, fragante, R.L. Dressler 5290, holo. US(not seen).

Hemiepiphytic vine, leafy, up to at least $8 \mathrm{~m}$ high. Stems somewhat fleshy, 7-10 mm thick; internodes 4.8-7.5 cm long. Adventitious attaching roots dorsiventrally compressed, at least up to $6 \mathrm{~cm}$ long, ca. $4 \mathrm{~mm}$ wide; adventitious free roots subterete, ca. $3 \mathrm{~cm}$ long, $2 \mathrm{~mm}$ wide. Leaves petiolate, the petiole 1.5-2.5 cm long; blade elliptic or elliptic-oblong to obovate, long acuminate, leathery, relatively thin, 15$30 \times 5.5-7 \mathrm{~cm}$. Inflorescence usually on the lower part of the stem, a 1-2(-4) flowered raceme, 13-15 mm long. Bracts lanceolate, 15-20 mm long. Flowers with spreading segments, sepals pale green, petals greenish cream, lip cream, the blade yellow-brown with a white margin, the throat with yellow-brown veins. Ovary ca. $4 \mathrm{~cm}$ long. Dorsal sepal lanceolate, obtuse, subclawed, the claw ca. $40 \mathrm{~mm}$ long, $8 \mathrm{~mm}$ wide, $11-11.5 \times 1.6-1.8$ $\mathrm{cm}$. Lateral sepals elliptic, subclawed, the claw ca. $40 \mathrm{~mm}$ long, $8 \mathrm{~mm}$ wide; $10.5-11 \times 1.8-2 \mathrm{~cm}$. Petals narrowly oblanceolate, obtuse, with a prominent rib on the outer surface, $10.8-11 \times 1.6-1.8 \mathrm{~cm}$. Lip attached to the column along the margins of the basal half (ca. 6.5$7 \mathrm{~cm}$ long), when flattened $11.5 \times 5.5 \mathrm{~cm}$; unguiculate, 


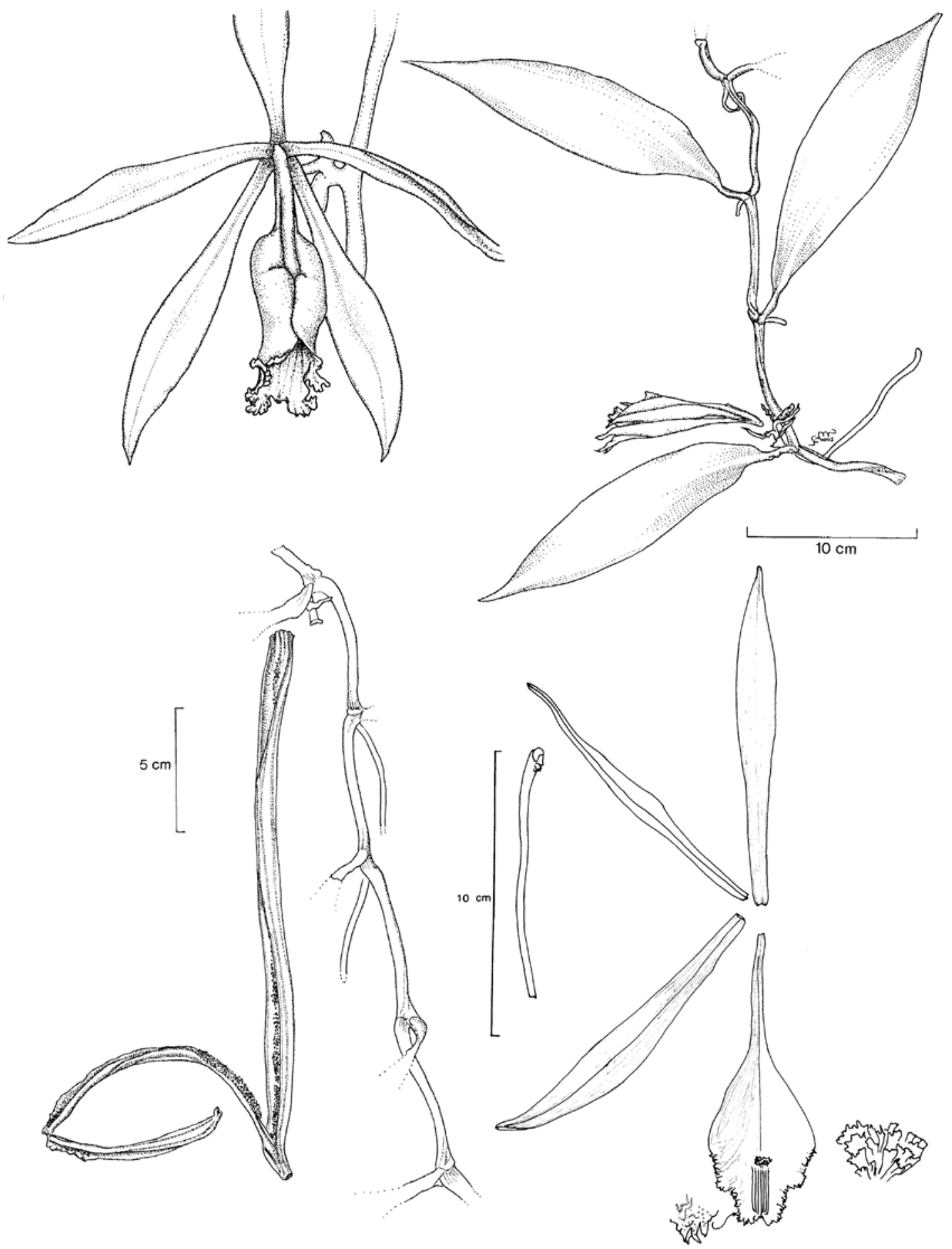

FIGURE 15. Vanilla trigonocarpa Hoehne. Based on McPherson 11286 (plant, flower dissection), Dressler 4750 (fruit), Collingram \& Ugoccioni 912 (flower, lateral view) and Dressler s.n. published picture. Drawing by M. López and M. Soto. 
claw ca. $4 \mathrm{~cm}$, then expanding abruptely and somewhat campanulate, inflated blade; the blade entire, margin strongly ruffled, ovate, ca. $11.5 \mathrm{~cm}$ long; penicillate callus made up by several laciniate scales, $5 \times 5 \mathrm{~mm}$; with a verruculose ridge running toward the apex; lip apex strongly veined. Column elongate, ca. $80 \mathrm{~mm}$ long, slightly arched, ventral surface pilose toward the apex (for ca. $3 \mathrm{~cm}$ ); with small wings. Stigma trilobed, the lobes emergent, the mid-lobe the largest. Anther ventral, $6 \times 4 \mathrm{~mm}$. Fruit cylindrical, 20-23 cm long, ca. $1.8 \mathrm{~cm}$ wide; somewhat triangular in cross-section, dehiscent; the seeds subspheric, somewhat flattened, black and shiny, ca. $0.6 \mathrm{~mm}$ long. Fig. 15.

Distribution: Costa Rica, Panama, and Brazil, and probably in the intermediate areas.

ECOLOGY: From very wet rainforest, from 120 to 350 $\mathrm{m}$ altitude; it can be common in certain areas. Flowers in Central America in January-February, and July; perhaps all year. Hoehne (1945) indicates that the flowers have a disagreeable fragrance, but that of the fruits is pleasant. Dressler (pers. com.) has observed males of Euglossa asarophora pollinating this species in Panama.

This species has been known in recent years in Central America as Vanilla pauciflora Dressler, but the Central American specimens are apparently conspecific with the Brazilian plant earlier described by Hoehne as $V$. trigonocarpa.

Vanilla trigonocarpa is somewhat variable in the form of the apical lobe of the lip, deeply retuse in the type and truncate to slightly emarginate in the Central American specimens. It is also variable in the development of the lacerate margins. The type specimen is minutely lacerate, as it is the specimen $T$. Antonio 3645, however, other specimens are deeply lacerate, as G. McPherson 11286.

Vanilla trigonocarpa is distinguished by the very large flowers on very short racemes with only 1-4 flowers with lanceolate, long acuminate bracts; the inflated lip, and strongly ruffled margins are also characteristic. It is probably related to $V$. espondae (and perhaps to V. sprucei), from Colombia, with flowers of the same color, but with shorter and broader segments, and the lip with an oblong-rounded midlobe covered with digitiform papillae, up to $3.5 \mathrm{~mm}$ long. Molecular analyses show that $V$. trigonocarpa is the most basal species among the American penicillate Vanillas.

OTHER RECORDS: COSTA RICA: PUNTARENAS: at base of Osa Península, ca. $25 \mathrm{~km}$ E of Rincón along newly improved road; elev $350 \mathrm{~m}$, climbing on tree in mature rainforest, 4 Jan 1986, P.M. Catling \& V. Brownell C24.1 AMES! PANAMA: PANAMA: El Llano-Cartí road, 10.1 miles from highway, on trail to west; $9^{\circ} 15^{\prime} \mathrm{N}, 79^{\circ} 00^{\prime} \mathrm{W}$; c. $350 \mathrm{~m}$. Epiphytic on trunk; perianth green-white, the frilly portion of lip brown, 16 July 1987, G. McPherson 11286 *MO(3499115)! about $10 \mathrm{~km}$ north of El Llano, 29 January 1974; vine, flowers borne from leafless stem, sepals and petals greenish cream, lip cream, streaked with brownyellow within, center of limb brown-yellow, R.L. Dressler 4571 (PMA, SEL); El Llano-Cartí highway, 10-12 km north of El Llano, 12 September 1974; climbing vine, about $8 \mathrm{~m}$, R.L. Dressler 4750 PMA, SEL *US(2952908)! COCLE: On the Atlantic side, ca. $5 \mathrm{hr}$ walk from sawmill at El Copé. Along slopes above Norte Río Blanco near small village of Caño Sucio; elev. 400-500 ft. Epiphyte vine on side of tree; flowers a beautiful cream white; lip yellow - very fragrant, 2 Feb 1980, T. Antonio $3645 * \mathrm{MO}(2928700)$ ! WITHOUT LOCALITY: leg.: Collector unknown. Selby Accession: 89-0281. Growing in Selby Display House. 26 April 1991. Coll. Ingram \& Ugoccioni $912 * \operatorname{SEL}(065176)$ !

REFERENCES: Hoehne, Fl. Bras. 13(2): 28, t. 20. 1945.

\section{Excluded species}

Vanilla barbellata Rchb.f., Flora 48: 274. 1865.

A horticultural specimen grown in Austria, supposedly from Cahuita, Costa Rica, seems to be the West Indian $V$. barbellata. There is a plate prepared by the artists of the Royal Botanical Expedition to New Spain, circa 1800 (Hunt Library; tracing at Library of MEXU (as "112 Vanilla mexicana"), G, and tracings probably elsewhere) that represents this species. The flower has scale-like leaves and hirsute lip. The Mexican origin of the plant is doubtful, since there are no confirmed records of leafless vanillas in mainland Mesoamerica. Many other paintings labeled as from Mexico ("de México") are actually Cuban plants, prepared during the stay of the Expedition at the island. As far as we know, Vanilla barbellata has been found only in Bahamas, Florida, Cuba, Puerto Rico, and theVirgin Islands.

Vanilla mexicana Miller, Gard. Dict. ed. 8: n. 1. 1768.

TYPE: Haiti, Plumier s.n., the holotype is Plumier's original drawing at $\mathrm{P}$; reproduction Plumier, Nov. 

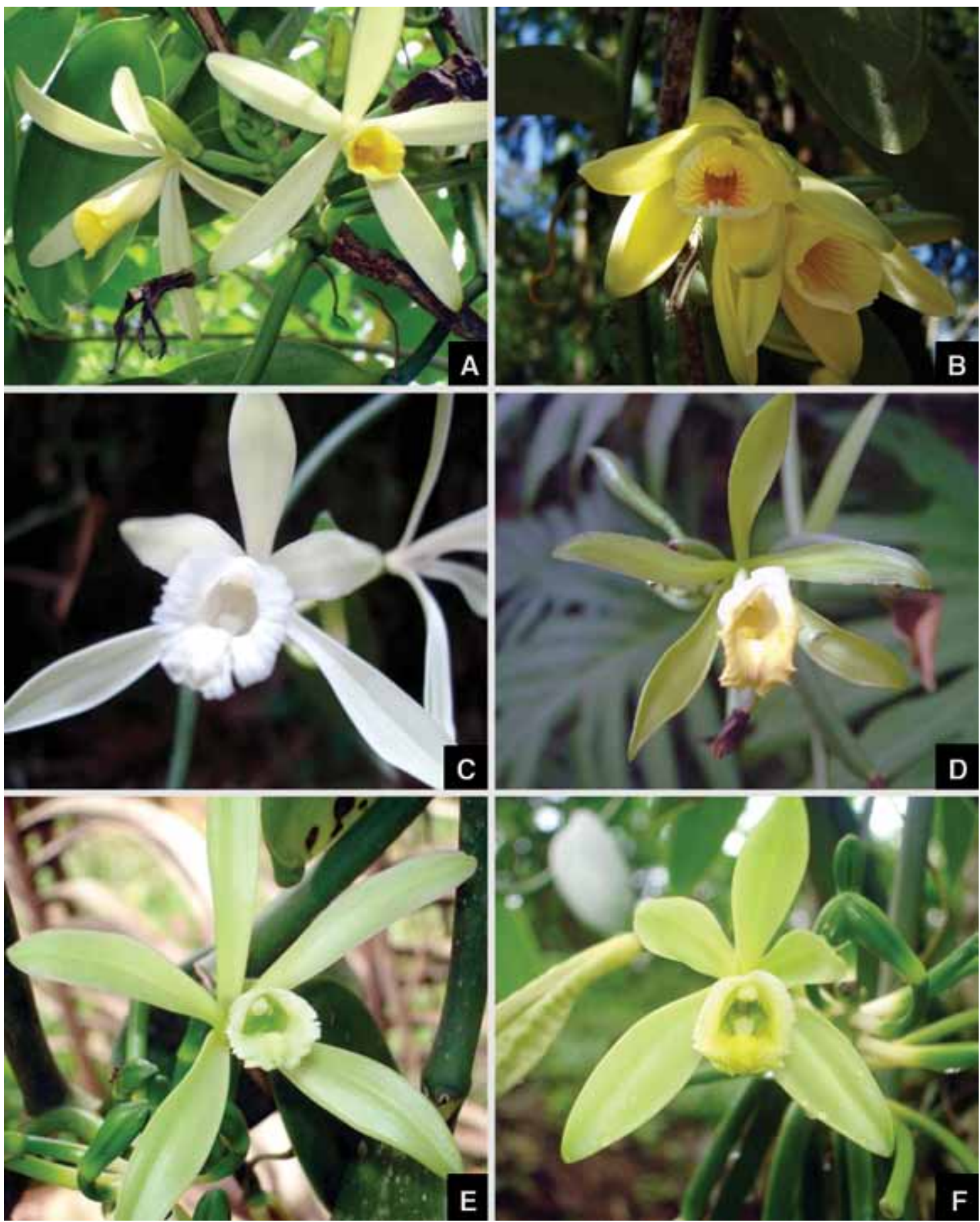

FigURE 16. A - Vanilla cribbiana. B - Vanilla dressleri. C - Vanilla hartii. D - Vanilla phaeantha. E, F - Vanilla planifolia. 

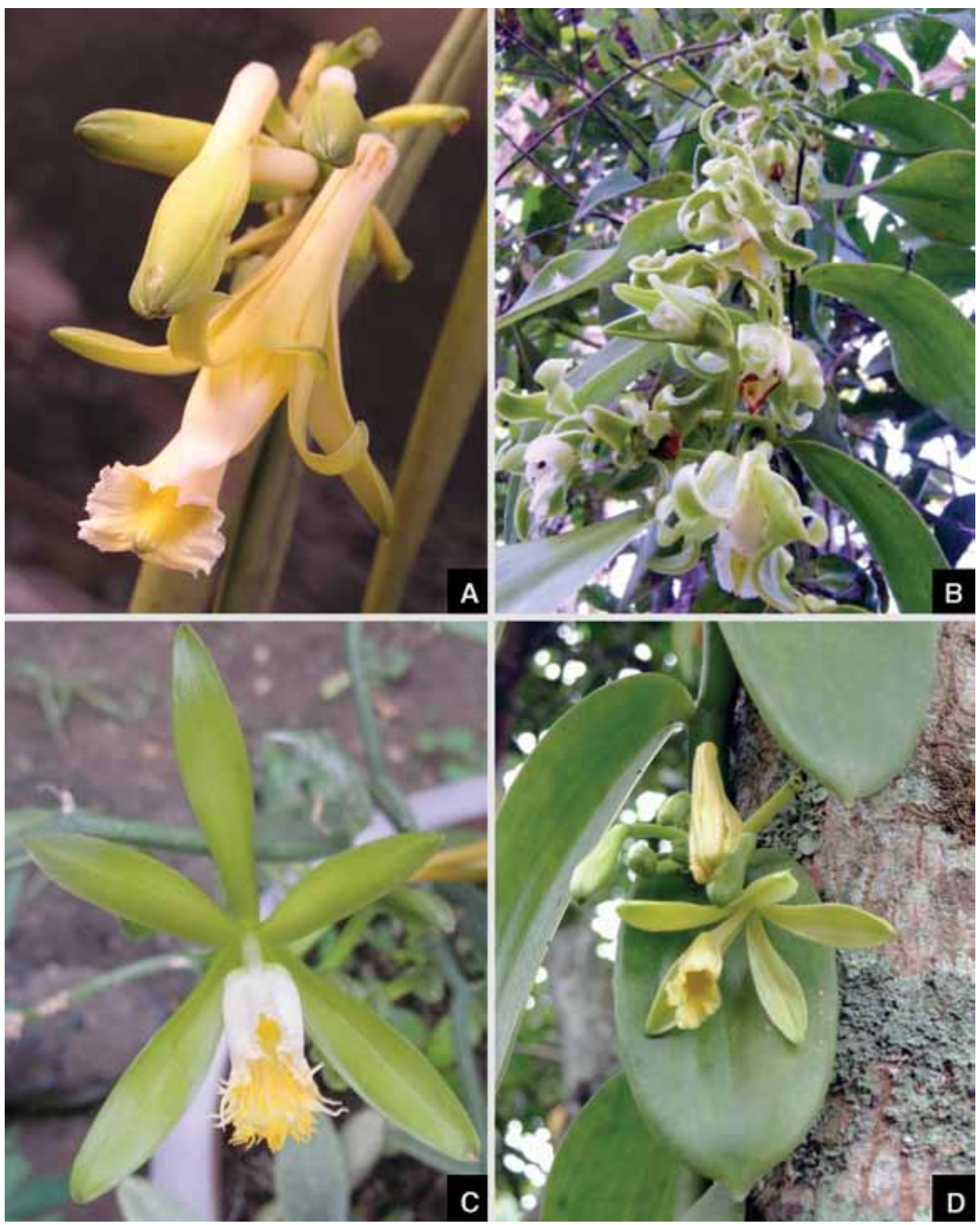

FIGURE 17. A - Vanilla calyculata. B - Vanilla guianensis. C — Vanilla insignis. D — Vanilla phaeantha. 
Pl. Amer. Genera 25, pl. 28, 1703 !

Epidendrum vanilla L., Sp. Pl. ed. 1, 2: 952. 1753.

Lectotype (icon designated by Cribb, Taxon: 48(1): 47. 1999): "Volubilis siliquosa plantaginis folio" in Catesby, Nat. Hist. Carolina 2 (3): app. t. 7. 1747.

V. vanilla (L.) Britton in Britton \& Wilson, Bot. Porto Rico 5: 185. 1924.

Syn: $V$. aromatica $\mathrm{L}$. (based on the same specimen).

V. aromatica Sw., Nov. Act. Soc. Sc. Upsal. 6: 66. 1799.

TYPE: Haiti, Plumier s.n., the holotype is the original drawing by Plumier.

V. anaromatica Griseb. Fl. Brit. W. Ind. 638. (?)

V. epidendrum Mirbel, Hist. Pl. ed. II. 9: 249. 1802-6.

V. vanilla Karst. Deutsch Fl. ed. 2, 1: 474.1895.

V. vanilla Huth, Helios 11: 136. 1893.

Vanilla mexicana has been repeatedly cited from Central America because the prevailing confusion between this species and Vanilla inodora. In spite of its name, it is a plant from the West Indies and northeastern South America. It is recognized by the large flowers with apple-green tepals and white, distinctly trilobed, 3-keeled lip. Other specimens labeled as $V$. mexicana from Costa Rica belong to the new species here proposed as $V$. costaricensis.

Vanilla planifolia Jackson $\mathrm{X}$ V pompona Schiede $\mathrm{x} \boldsymbol{V}$. planifolia Jackson

This artificial hybrid was created in Madagascar. It was imported to Costa Rica, where is rather common, and it is said that it is very resistant to root rot disease (David Gardella, com. pers.). ITS sequences are polymorphic and similar to both $V$. pompona subsp. grandiflora and to V. planifolia. MatK and $\mathrm{rbcL}$ sequences are grouped with $V$. planifolia sequences, which suggest that $V$. planifolia was used as the maternal progenitor, since the plastid genome is inherited maternally.

Vanilla $\mathrm{x}$ tahitensis J.W.Moore, Bishop Mus. Bull. Bot. 102: 25. 1933.

TYPE: Flora of the Society Islands, Island of
Raiatea, altitude $20 \mathrm{~m}$; on trees, escaped from cultivation; 3rd valley south of Faaroa Bay, 2-3 dm high. Native name Vanira tahiti, Nov. 11, 1923, J.W. Moore 294, holo. Bernice P. Bishop Museum Herbarium (559503)!

V. hirsuta M.A. Clements \& D.L. Jones, Lasianthera 1(1): 47. 1996

TYPE: Papua New Guinea, M.A. Clements 6742 CANB(holo.) iso(NCBG) not seen, photo!

AdDitional SPECIMENS: FRENCH POLYNESIA: Raiatea: H. St. Johns 17310 K! Mongareva Is. H. St. Johns 14459 K(drawing)!

Vanilla tiarei Constantin \& bois, Compt. Rend. 1915 161: 202, nomem

TYPE: Tahiti.

Distribution: Known from French Polynesia (Society Islands), and New Guinea. The Tahitian vanilla certainly is not known in Central America.

Vanilla tahitiensis J.W. Moore was described from material from Raiatea, Society Islands. The type corresponds to the plant widely cultivated in French Polynesia and known as "Vanille de Tahiti", and the second most important source of commercial vanilla. The same taxon was also recently redescribed by Clements \& Jones (1996) as $V$. hirsuta, based on a specimen collected in Papua New Guinea (M.A. Clements 6742 CANB(holotype), NCBG(isotype) not seen, photos!). There are also other different plants in Tahiti, including $V$. planifolia, and some variants of $V$. tahitiensis that may represent different cultivars or different species (e.g. a plant labeled as cv. Tahita is apparently $V$. bahiana).

Porteres (1954) indicated that the origin of $V$. tahitiensis was very enigmatic. It has been suggested also that the distribution of $V$. tahitiensis is far from other vanillas, that its occurrence in Tahiti is perhaps due to a human introduction, and that it is very similar to V.planifolia and not to the species from New Guinea, which is the area with native vanillas closest to Tahiti, such as $V$. giulianettii F.M. Bayley, V. kaniensis Schltr., V. kempteriana Schltr., V. ramificans (J.J. Sm.) J.J. Sm., V. wariensis Schltr.

Except for $V$. tahitiensis, all the Vanilla species with aromatic fruits are restricted to the Neotropics (Soto, 2003). Occasional reports of fragrant fruits in Asia (e.g. Heyne, 1922) are probably based in wrong observations, or in odors unlike the typical vanilla fragrance. Vanilla 
lineages are confined to particular geographic areas, and disjunctions are better explained by ancient vicariant events than by long distance dispersal (Soto et al., in prep).

Vanilla (in the generic sense) was introduced to Tahiti from Manila about 1848. Pétard (1986: 123) claimed that Admiral Hamelin was responsible for bringing the plants to the Botanic Garden at Papeete, whereas Herman et al. (1989: 20) asserted that William Ellis, a missionary from London Misionary Society, brought cuttings from the Philippines (Smith et al., 1992). Ryan (1986) agrees that the origin of $V$. tahitiensis is uncertain, she said that it may be that some Vanilla planifolia plant stock was hybridized or that it mutated, allegedly in the Philippines and that $V$. tahitiensis is not native of the South Pacific Islands, but she did not give more data about this statement, although she indicates Tahitian growers as the source of the information.

Morphological variation in Vanilla planifolia is rather great, but it is clear that traits exhibited by $V$. tahitensis depart from the known variation of $V$. planifolia. It is difficult to think of a somatic mutation than could cause such conspicuous differences. Sexual reproduction of vanilla is almost impossible under plantation conditions, and the life span is long enough to discard rapid artificial selection as a probable source of such "novelties". Therefore, the hybrid hypothesis is more plausible.

The hybrid origin of $V$. tahitiensis was suspected by Portères (1954) and Pétard (1986), who suggested that it arose from a cross between $V$. fragrans $(=V$. planifolia) and $V$. pompona. Vanilla tahitiensis is morphologically very similar to $V$. planifolia and its allies, especially $V$. odorata and $V$. insignis, but not to $V$. pompona. The hybrid between $[V$. pompona $\times \quad V$. planifolia $] \mathbf{x}$ $V$. planifolia has thicker stems, leaves, and different flowers than $V$. tahitensis.

Compared to $V$. planifolia, $V$. tahitensis has retrorse warts on the midlobe of the lip. Since this trait is a synapomorphy of the group of $V$. odorata (including $V$. odorata, V. fimbriata, $V$. helleri, and $V$. insignis, and also $V$. cristagalli and $V$. ribeiroi from South America), if of hybrid origin one of these taxa is the candidate for parental species in addition to $V$. planifolia. $V$. helleri has a very short lip claw, and widely elliptic leaves, broader than either in V. planifolia or V. tahitensis. $V$. insignis has conspicuously sulcate, papillose stems, and leaves similar in shape to $V$. planifolia. Since $V$. tahitensis has slender stems, narrower leaves, longer perianth segments and column, the best candidates for a parental species are V. odorata and V. fimbriata (if this is specifically distinct from $V$. odorata), both with slender stems, narrower leaves, longer perianth segments and column, than V. planifolia and V. tahitensis.

Vanilla odorata is an important source of vanilla fruits from the wild. Most vanilla beans collected by peasants in Chiapas, Mexico are from V. odorata, since wild V. planifolia is extremely rare or absent. Ames also reported that it was the best quality species in Ecuador; and herbarium records from Bolivia indicate that "it was the best one there". Furthermore, $V$. odorata has some interesting features that make it a good candidate in a Vanilla hybridization program, such as the higher tolerance to more open habitats, its origin from places with higher annual rainfall and more equatorial climates, tolerant to occasionally flooded terrains, and its resistance to the attack of "chinche roja" (Tentecoris confusus) (M. Soto, pers. observations); nothing is known about its resistance to fungal and bacterial diseases, but it seems not as susceptible as $V$. planifolia (M. Soto, pers. obs.). Vanilla planifolia and V. odorata may be sympatric in several regions of Central America. In Northern Oaxaca, Mexico, both species have been found intermingled and flowering at the same time. Both species are probably pollinated by Euglossine bees (apparently Euglossa viridissima in the case of V. planifolia) involving a pollination system involving deception. Fragrance analysis

Vanilla tahitiensis is the only Vanilla species from which there are reports of diploid and tetraploid chromosome counts. Tonier (1951) reported 64 somatic chromosomes for "Vanilla haapape"(sic), considered to be a variety of $V$. tahitiensis (R. Porterès, 1954), while Heftimiu-Heim (1941) reported $2 \mathrm{n}=32$ for $V$. tahiti (sic) and $V$. papeno (sic), the later a common name of $V$. tahitiensis var. haapape (Porterès op. cit.).

ITS sequences of a specimen of $V$. tahitensis cultivated in France, and another gathered from the Gene Bank as $V$. hirsuta are nested into one of the clades of $V$. odorata with $100 \%$ of bootstrap support (other specimens of $V$. odorata have an ITS sequence more similar to that of $V$. helleri).

Although we do not have flowering material of $V$. tahitensis to make a quantitative analysis of the 
intermediate morphology character of it between $V$. planifolia and $V$. odorata, qualitative data support the hybrid origin between these species. ITS sequences indicate an extremely close relationship with $\mathrm{V}$. odorata However, Schlüter found that was no evidence of a hybrid origin analysing.

In conclusion, it is suggested that $V$. tahitensis is a taxon of hybrid origin between $V$. odorata and $V$. planifolia introduced to Tahiti from Phillipines. Lubinsky et al. (2008) provide strong support for the hybrid origin of $V$. tahitensis from cross(es) of $V$. planifolia and $V$. odorata. It is not improbable that this cross was taken from Mexico to the Philippines when both countries were ruled by the Spanish crown and subject to a large commercial exchange thanks to the Manila Galleon, that connected Acapulco with the far east. The large variation observed (Maurice Wong, pers, com.) and detected by RAPDs in the tahitian vanilla is an additional point that supports its hybrid origin. Lubinsky et al. (2008) have suggested that $\mathrm{V}$. xtahitensis can be an artificial hybrid and even postulated a postclassic origin. Orchid hybridization and subsequent germination of the sclerotic seeds is almost impossible under primitive conditions. Even now, Vanilla seeds are planted from immature fruits in which the testa have not become hard and it is thought that mature seeds in ripe fruits must pass through the digestive tract of a bat to germinate under natural conditions. Given the sympatricity of $V$. planifolia and $V$. odorata, the same flowering season, and the prevalence of the similar herbal aroma with cinnamon-like notes in both species, is not unlikely that they share the same pollinator, apparently Euglossa viridissima in $V$. planifolia. Therefore, a spontaneous hybrid between $V$. planifolia and $V$. odorata may be the source of $V . x$ tahitenss, with a later selfing or backcrossing with $V$. planifolia, already in Tahiti, that gave origin to the variation in cultivars, genotypes and chromosomic numbers.

The following specimens are sterile, but their leaf morphology is so different to the rest of the Central American Vanilla, that we are convinced that they represent a different, undescribed species. The leaves are rather thin, but not as thin as those of subsect. Membranacea; the leaves are conspicuously obovate and abruptly mucronate.
COSTA RICA: CARTAGO: Sin flores ni frutos, Instituto [Interamericano de Ciencias Agrícolas], Turrialba, en el bosque, 600 m alt., 23-VIII-49, J. Léon 1692 US(2021492)! GUANACASTE: Large epiphytic vine in moist forest, El Silencio, near Tilarán, altitude about 750 m, Jan. 13, 1926, P.C. Standley \& J. Valerio 44791 US(1309513)!

There are very few records on vanilla dispersal, but bat dispersal had been suggested in $V$. insignis (M. Soto, unpublished data) and recently observed in $V$. pompona (N. Byrd, pers. com.). Bird dispersal is expected in some Asian species, as $V$. abundiflora J.J. Smith and $V$. griffithii Rchb. f., and also in the closely related genera Cyrtosia.

AcKNOWLEDGMENTs. Thanks are due to Bush Boake Allen Ltd. (BBA), London, for the financial support to develop this work, especially to Drs. John Janes, Angela Ryan and Neil C. Da Costa. Dr. Phillip J. Cribb, Royal Botanic Gardens, Kew, encouraged us to conduct this work. The Comisión Nacional para el Conocimiento y Uso de la Biodiversidad, Mexico (CONABIO, Project J-101) financed part of the analysis of nucleotidic sequences of Mexican taxa. We are in debt to the keepers of the following herbaria, for permission to study the collections in their charge: AMO, AMES, BM, BR, CHAPA, CR, EAP, ENCB, F, G, GOEL, HEPF, INB, K, LL, MA, MEXU, MO, NY, P, RJ, SCZ, SEL, UCR, US, UV, W, WU, and XAL. Dr. Kenneth M. Cameron, Wisconsin, for sharing his ITS sequences of Epistephium and Lecanorchis. To the Unión de Vainilleros de San Felipe Usila, Oaxaca, to Ing. Heriberto Larios, for the facilities to visit and work in plantations in Oaxaca and Veracruz, Mexico. To Mariana Hernández and Angélica Cibrián, who assisted MAS in the field work. To Eric Hágsater who placed at our disposal the facilities of AMO Herbarium. To the Dirección General de Conservación Ecológica, Secretaría de Medio Ambiente, Recursos Naturales y Pesca (now SEMARNAT), Mexico, for the permits for collecting vanillas in Mexico, particularly in regions under the National System of Natural Protected Areas. To the staff of the Biosphere Reserve of Calakmul, Campeche, particularly to Esteban Martínez, who made it possible to study the populations of Vanilla insignis. Julio Arguijo guided MAS in Central Veracruz to locate wild plants of $V$. planifolia and V. pompona. To the staff of the Station of Tropical Biology, Chajul, Chiapas, for the facilities to work in the reserve. To Ulises Sánchez, who collected spirit preserved material of the region Mazateca, in Oaxaca. To Dr. Thomas Wendt and the National Geographic Society for the logistics for the expedition to the region of UxpanapaSierra Tres Picos. To Dr. Germán Carnevali (CICY, Mérida, Mex.) and Joao Batista da Silva, from Belém, Brazil, who 
gave us material from Venezuela and Brazil, extremely useful to confirm the limits of the Central American taxa. To José Linares, Escuela Agrícola Panamericana, El Zamorano, Honduras, for information and material of V. calyculata, and other species. To Febronio Tun López, for information on the vanillas of northern Guatemala. To Prof. William Stern, Florida State Museum for material of V. trigonocarpa. To Dr. Thomas Croat, Missouri Botanical Garden, for access to material grown at the garden. To Mr. Neal Byrd, Cía. Agrícola La Gavilana Ltd., Costa Rica, and Professor Franco Pupulin for invaluable material and information on Costa Rican species. To M.Sc. Elvira Salas, Universidad de Costa Rica, for her help with Costa Rican materials. To Rolando Jiménez and Marco López, who prepared several illustrations. To Dr. Gerardo A. Salazar for constant help, support and comments during the preparation of this work. To Msc. Laura Márquez Valdelamar, Lab. de Bología Molecular, Instituto de Biología, UNAM, by sequencing labour. Finally, to our team in the Laboratorio de Genética Molecular y Evolución Instituto de Ecología, UNAM, especially to Ms. Angeles Cortéz, M.Sc. Rosalinda Tapia, Drs. Alicia Gamboa, Caroline Burgeff, and Francisca Acevedo for all their help in the laboratory.

\section{LiteRATURE CITED}

Acuña, G.J. 1939. Catálogo descritivo de las orquídeas cubanas: 22 .

Ames, O. 1934. An addition to the genus Vanilla. Bot. Mus. Leafl. 2(8): 101-103.

Ames, O. and D.S. Correll. 1952. Orchids of Guatemala. Fieldiana: Bot. 26: 54-60.

Boldó, B. \& J. Estévez. 1990. Cubensis prima flora. Fontqueria 29: 160-161.

Bouriquet, G. 1954. Le vanillier et la vanille dans le monde. en R. Portéres [ed.] Encyclopédie Biologique 46. Paul Lechavalier. Paris.

Britton, N.L. \& C.F. Millspaug. 1962. The Bahama flora: 83-84.

Bruman H. 1948. The culture history of mexican vanilla. Hisp. Am. Hist. Rev. 28(3), 360-376.

Cameron, K.M. 2000. Gondwanan biogeography of Vanilloideae (Orchidaceae). Southern Connections Congress, Program and Abstracts: 25-26. Lincoln, New Zealand.

Cameron, K. 2003. Vanilloideae. Pp. 281-285 In: Pridgeon, A.M., P.J. Cribb, M.W. Chase \& F.N. Rasmussen. (eds.), Genera Orchidacearum vol. 3. Orchidoideae (Part two), Vanilloideae. Oxford University Press. Oxford.

Carnevali F.-C., G., J.L. Tapia M., R. Jiménez M., L. Sánchez S., L. Ibarra G., I. M. Ramírez \& M. P. Gómez. 2001. Notes on the flora of the Yucatan Peninsula II: A synopsis of the orchid flora of the Mexican Yucatan
Peninsula and a tentative checklist of the orchidaceae of the Yucatan Peninsula Biotic Province. Harv. Pap. Bot. 5(2): 383-466.

Castillo Martínez, R. \& E.M. Engleman. 1993. Caracterización de dos tipos de Vanilla planifolia. Acta Bot. Mex. 25: 49-59.

Chase, M.W. 2001. The origin and biogeography of Orchidaceae. pp. 1-5 In: A.M. Pridgeon, P.J. Cribb, M.W. Chase \& F.N. Rasmussen. (eds.), Genera Orchidacearum vol. 2. Orchidoideae (Part one). Oxford University Press. Oxford.

Chase, M.W. \& H.G. Hills. 1991. Silica gel: An ideal material for field prservation of leaf samples for DNA studies. Taxon 40(2); 215-220.

Childers, N.F., H.R. Cibes \& M.E., Hernández. 1959. Vanilla- The orchid of commerce. Pp. 477-508 in: C.L. Withner (ed.), The Orchids. A scientific survey. Ronald Press Co. New York.

Cibrián, J.A. 1999. Variación genética de Vanilla planifolia en México. Thesis. Faculty of Sciences, National University of Mexico, Mexico City. 60 pp.

Correll, D.S. 1944. Vanilla: its history, cultivation and importance. Lloydia 7, 236-264.

Correll, D.S. 1965. Supplement to orchids of Guatemala and British Honduras. Fieldiana: Bot.: 31(7): 725.

Croat, T.B. 1984. Flora of Barro Colorado Island. Stanford University Press.

Dix, M.A. \& M.W. Dix. 2000. Orchids of Guatemala. A revised annotated checklist. Monogr. Syst. Bot. Missouri Bot. Gard. 54 p.

Dressler, R.L. 1979. Una Vanilla notable de Panamá. Orquideología 13(3): 229-232.

Dressler, R.L. 1993. Field guide to the orchids of Costa Rica and Panama. Comstock Publishing Associates. Ithaca and London. Pp. 325-326.

Ehlers, D. \& M. Pfister. 1997. Compounds of Vanillons (Vanilla pompona Schiede). J. Essent. Oil Res. 9: 427431.

Fawcett, W. \& B. Rendle. 1910. Orchidaceae. In: Flora of Jamaica.

Foldats, E. 1969. Orchidaceae. In: Flora de Venezuela. vol. 15: 123-125, fig. 42.

Garay, L.A. \& H.R. Sweet. 1974. Orchidaceae. In: Flora of the Lesser Antilles.

Hágsater, E., M.A. Soto Arenas, G.A. Salazar Chávez, R. Jiménez Machorro, M.A. López Rosas \& R.L. Dressler. 2005. Las orquídeas de México. Instituto Chinoín A.C. México City.

Hamer, F. 1974. Las orquídeas de El Salvador. Ministerio de Educación. San Salvador.

Hamer, F. 1984. Orchids of Nicaragua, part 5. Ic. Pl. Trop. fasc. 12. The Marie Selby Botanical Gardens, Sarasota, Florida. 
Heller, A.H. \& A.D. Hawkes. 1966. Nicaraguan orchid studies. Phytologia 14(1): 1-37.

Hermann, B., J.C. Celhay, M. Guerin, J.M. Maclet \& J. Rentier. 1989. Fleurs et plantes de Tahiti. Les Editiones du Pacifique, Sangapore.

Hoehne, F.C. 1945. Flora Brasilica XII, II. Orchidaceae. (Texto e Ilustraçâo). Secretaria da Agricultura, Industria e Comércio de Sâo Paulo. Brasil. Tab. 20.

Kenny, J. 1988. Native orchids of the Eastern Caribbean. London, Macmillan Caribbean.

León, F.S.C. \& H. Alain. 1946. Flora de Cuba 1: 351.

Lubinsky, P., M. Van Dam \& A. Van Dam. 2006. Pollination of Vanilla and evolution in Orchidaceae. Lindleyana [Orchids] 76: 926-929.

Lubinsky, P., K. M. Cameron;, M. C. Molina, M. Wolng, S. Lepers-Andrzejewski, A. Gómez-Pompa, y SK. SeungChul. 2008. Neotropical roots of a Polynesian spice: the hybrid origin of Tahitian vanilla, Vanilla tahitensis (Orchidaceae). Amer. J. Botany 95(8): 1040-1047.

Luer, C.L. 1972. The native orchids of Florida. The New York Botanical Garden.

McLeish, I.M., N.R. Pearce \& B.R. Adams. 1995. Native orchids of Belize. A.A. Balkema. Rotterdam.

Murray, M.G. \& W.F. Thompson. 1980. Rapid isolation of high weight plant DNA. Nucl. Acids Res. 8: 4321-4325.

Pétard, P. 1986. Quelques plantes utiles de Polynésie française et Raau Tahiti. Editions Haere Po No Tahiti, Pepeete.

Portères, R. 1954. Le genre Vanilla et ses espèces. In: Lechevalier, P. (ed.). Le vanillier et la vanille dans le monde. Paris.

Purseglove, J. W. 1975. Tropical crops: Monocotyledons. J. Wiley, New York.

Purseglove, J. W., Brown, E. G., Green, C.L. \& Robbins, S. R .J. 1981. Spices, vol. 2. Longman, London.

Putz, F. E. \& Holbrook, N. M. 1986. Notes on the natural history of hemiepiphytes. Selbyana 9, 61-69.

Rain, P. 1986. Vanilla cookbook. Celestial Arts. Berkeley.

Ray, T. S. 1990. Metamorphosis in the Araceae. Amer. J. Bot. 77: 1599-1609.

Rodríguez C., R. L., D.E. Morta, M.E. Barahona, N.H. Williams. 1986. Géneros de orquídeas de Costa Rica: 70-71.

Rolfe, R.A. 1896. A revision of the genus Vanilla. J. Linn. Soc. 32: 439-478.

Roullet, J. Fleur noire-Legende-Voyage \& alea (Suite). L'Orchidee 12:28.

Roubik, D.W. \& J.D. Ackerman. 1987. Long-term ecology of euglossine orchid-bees (Apidae: Euglossini) in Panama. Oecologia (Berlin) 73: 321-333.

Savolainen, V., P. Cuénoud, R. Spichiger, M.d.P. Martínez, M. Crèvecoeur \& J.-F. Manen. 1995. The use of herbarium specimens in DNA phylogenetics: evaluation and improvement. Pl. Syst. Evol. 197: 87-98.

Schlüter, P.M., M.A. Soto Arenas \& S.A. Harris. 2007. Genetic variation in Vanilla planifolia (Orchidaceae). Econ. Bot. 61(4): 328-336

Schultes, R.E. 1960. Native orchids of Trinidad and Tobago: 39-40.

Smith, N. J. H., Williams, J. T., Plucknett, D. L. \& Talbot. J. P. 1992. Tropical forests and their crops, pp.357-364 . Cornell University Press. Ithaca.

Soto Arenas, M.A. 1989. Listado actualizado de las orquídeas de México. Orquídea (Méx.) 11: 233-277.

Soto Arenas, M.A. 1994. Vanilla odorata, una especie de amplia distribución. Orquídea (Méx.) 13(1-2): 295-300.

Soto Arenas, M.A. 1999. Filogeografía y recursos genéticos de las vainillas de México. Proyecto J-101. Mexico City.

Soto Arenas, M.A. 2003. Vanilla (generic treatment). Pp. 321-334 in: A.M. Pridgeon, P.J. Cribb, M.W. Chase \& F.N. Rasmussen. (eds.), Genera Orchidacearum vol. 3. Orchidoideae (Part two), Vanilloideae. Oxford University Press. Oxford.

Soto Arenas, M.A. 2003. Vanilla insignis Ames. Pl. 700 in: E. Hágsater \& M.A. Soto Arenas (eds.), Orchids of Mexico, parts 2 and 3. Icones Orchidacearum fasc. 6 and 6. Herbario AMO. México D.F.

Soto Arenas, M.A. \& P.J. Cribb. 2010. A new infrageneric classification and synopsis of the genus Vanilla Plum. ex Mill. (Orchidaceae, Vanillinae). Lankesteriana 9(3): 355-398.

Soto Arenas, M.A. \& R.L. Dressler. 2003. Vanilla. Pp. 583587 in: B.E. Hammel, M.H. Grayum, C. Herrera \& N. Zamora (eds.), Manual de plantas de Costa Rica, vol. 3 Monocotiledóneas (Orchidaceae-Zingiberaceae). Missouri Botanical Garden,-INBio-Museo Nacional de Costa Rica.

Soto-Arenas, M. A. \& A.R. Solano-Gómez. 2007. Ficha técnica de Vanilla planifolia. In: Soto-Arenas, M. A. (ed). Información actualizada sobre las especies de orquídeas del PROY-NOM-059-ECOL-2000. Instituto Chinoin A.C., Herbario de la Asociación Mexicana de Orquideología A.C. Bases de datos SNIB-CONABIO. Proyecto No. W029. México. D.F..

Toledo, V. M. 1982. Pleistocene changes of vegetation in tropical Mexico. Pp. 93-111 in: G.T. Prance (ed.) biological diversification in the tropics. Columbia University Press, New York.

Wendt, T. 1989. Las selvas de Uxpanapa, Veracruz-Oaxaca. Una evidencia de refugios florísticos cenozoicos. Anales Inst. Biol. Univ. Nal. Autón. Méx. ser. Bot. 58: 29-54.

Wendt, T. 1993. Composition, floristic affinities, and origins of the canopy tree flora of the Mexican Atlantic slope rain forest. In: T.P. Ramamoorthy, R. Bye, A. Lot and J. 
Fa (eds.), Biological diversity of Mexico. Origins and distribution. Oxford Univ. Press

Williams, L.O. 1951. The orchidaceae of Mexico. Ceiba 2: 34-35.

Williams, L.O. 1956. An enumeration of the Orchidaceae of Central America, British Honduras and Panama. Ceiba 5(1): 18 .
Williams, N. H. 1982. The biology of orchids and euglossine bees. Pp. 119-171 in: J. Arditti (ed.), Orchid Biology, Reviews and Perspectives, 2. Cornell University Press, Ithaca, New York.

Wood, J.J. 2003. Orchids of Borneo, vol. 4. Revised classification and selection of species. Sabah Society and Kew Publishing. 